\title{
APRENDIZAGENS E EXERCÍCIO PROFISSIONAL NA UFSM: UM INSTRUMENTO NA SINFONIA DA VIDA
}

\author{
http://dx.doi.org/10.5902/2318133867467
}

\author{
Estela Maris Giordani ${ }^{1}$
}

\begin{abstract}
Resumo
O percurso aprendido do ser pessoa e profissional ocorre por meio de muitos desafios ao longo das vivências nas quais se constroem relações e estruturas que, por sua vez, impactam outros com a presença do testemunho da ação de sucesso. O texto, de forma reflexiva, expõe por meio de uma narrativa autobiográfica, uma trajetória singular de aprendizagens marcadas pela formação e atuação no ensino, pesquisa e extensão. A motivação foi a elaboração de um memorial para a ascensão ao último nível da carreira professor titular da Universidade Federal de Santa Maria. As múltiplas aprendizagens vão emergindo a partir das experiências em classes multisseriadas à docência na pós-graduação na América Latina; à Especialização Profissional em Psicologia, com abordagem em Ontopsicologia na Universidade Estatal de São Petersburgo e as parcerias em pesquisa e formação com a Universidade de Genebra/Faculdade de Ciências da Educação; a participação em bancas de doutorado nesta última e na Universidade de Santiago de Compostela; as participações em gestão na coordenação do Mestrado Acadêmico em Educação e nos cursos de Pedagogia; nas orientações de pesquisas, seja na iniciação científica, em trabalhos de conclusão de cursos de graduação, especialização, dissertação ou tese de doutorado; na condução de pesquisas, escrita de livros, artigos e participação em tantos eventos acadêmicos; mas, sobretudo, no dia a dia dos desafios da docência ao longo de três décadas, agora na quarta. Toda trajetória de aprendizado foi conduzida pelo Maestro Antonio Meneghetti que, por meio da Pedagogia Ontopsicológica, me coadjuvou a cunhar a parte mais difícil, delicada e importante de minha profissão pedagoga, minha personalidade.
\end{abstract}

Palavras-chave: aprendizagem do pedagogo; formação; pedagogia ontopsicológica.

\section{LEARNING AND PROFESSIONAL EXERCISE AT UFSM: AN INSTRUMENT IN THE SYMPHONY OF LIFE}

\section{Abstract}

The path learned from being a person and a professional occurs through many challenges throughout the experiences in which relationships and structures are built that, in turn, impact others with the presence of the testimony of the successful action. The text, in a reflexive way, exposes, through an autobiographical narrative, a singular trajectory of learning marked by training and performance in teaching, research and extension. The motivation was the elaboration of a memorial for the ascension to the last level of the career titular professor at the Federal University of Santa Maria. Multiple learning emerges from experiences in multigrade classes to teaching in Postgraduate Studies in Latin America; the Professional Specialization in Psychology, with an Ontopsychology approach at the State University of St. Petersburg and the partnerships in research and training with the University of Geneva/Faculty of Educational Sciences (SU); participation in doctoral boards in the latter and in the University of Santiago de Compostela;

1 Universidade Federal de Santa Maria, Brasil. E-mail: estela.giordani@ufsm.br. 
participation in management in coordinating the Academic Masters in Education and in Pedagogy courses; in research guidelines, whether in IC, undergraduate TCC, specialization, dissertation or doctoral thesis; conducting research, writing books, articles and participating in many academic events; but above all, in the day-to-day challenges of teaching over three decades, now on the fourth. The entire learning trajectory was led by Maestro Antonio Meneghetti who, through Ontopsychological Pedagogy, helped me to coin the most difficult, delicate and important part of my teaching profession, my personality.

Key-words: pedagogue learning; formation; ontopsychological pedagogy.

\section{Introdução}

trajetória profissional consiste numa decisão existencial, uma escolha do $\triangle$ como viver uma dimensão importante da própria personalidade, uma dimensão de serviço e contributo ao outro ser humano que, como você, necessita de tantos outros para poder existir conforme a escolha que faz (Meneghetti, 2006). E quando a escolha reflete o projeto que a vida o presenteou, então não há dificuldade que não se torne. Neste, estão contatadas, em primeira pessoa, portanto, com muitas marcas de subjetividade, a trajetória formativa e as vivências profissionais. A aprendizagem é um ato voluntário que deriva de uma intenção interior, a estrutura psíquica do 'eu lógico histórico' decide, a partir de dentro, encontrar-se com um outro, a partir de dentro e então, apropriar-se com evidência de algo que pode ser idêntico ou não a si, e, se for idêntico, fazer parte de si. Partindo da premissa da Pedagogia Ontopsicológica busquei exercer minha atividade profissional como uma servidora da vida no contexto da Universidade Federal de Santa Maria.

$O$ texto foi escrito em formato de narrativa pessoal trazendo movimentos formativos antes do ingresso na UFSM, na primeira parte. A segunda parte expressa algumas das tantas práticas profissionais e aprendizagens do período em ingressei na UFSM até o momento da defesa do memorial. Neste percurso foram expressas as atividades docentes no ensino, pesquisa e extensão. Não trago à tona toda a riqueza de aprendizagens, algumas compõe esse texto, outras não. Contudo, expõe sínteses existências profundas que podem iluminar outros percursos existenciais. Neste sentido, me tornando um instrumento que toca outros tantos, na sinfonia da vida.

\section{Trajetória formativa: aprendendo a profissão docente no chão da sala de aula}

Filha de professora, minha mãe me levava seguidamente na escolinha de chão batido, com classes de dois alunos, na classe que era multisseriada na Esquina Michalski - Tucunduva/RS. Estudavam lá outras crianças com muitas diferenças, mas eu apreciava muito estar na condição de filha da professora, porque assim cumpria o papel de 'monitora' da professora, a qual obviamente era a minha mãe. Da direção/secretaria à cozinha e a sala de aula, naquela planície que se avistava longe e se ouvia o Minuano entre as janelas e o lindo bosque de eucaliptos fui iniciada na minha carreira docente. Tudo se fazia na escola, as festas, os encontros dominicais com as celebrações realizadas pelo ministro da eucaristia. Este foi o espaço no qual fui sendo esculpida para ser professora, sem perceber e entender. Esse tempo marcou muito. Apesar de ser tudo muito simples, era um lugar em que ouvia os múltiplos sons da natureza, pássaros, vento 
tocando nas árvores e sentia os aromas da terra, das árvores, das flores, do pó do giz, e o inconfundível aroma delicioso dos eucaliptos. E, tudo isso, no ambiente da única sala da escolinha com as suas classes duplas - para duas crianças - de madeiras e inclinadas, ergonômicas. Ambiente cercado de natureza: as lavouras de soja, trigo e milho, mata nativa. Deste tempo aprendi a simplicidade e o convívio com tantas pessoas de diferentes classes e situações sociais, a vivência em comunidade, a relação importante entre a escola e a comunidade e fundamentalmente o amor e dedicação pela docência.

Com 11 anos já era responsável por toda a lida doméstica: cuidar das minhas outras duas irmãs menores - pois sou primogênita de outras duas mulheres -, fazer a limpeza da casa e preparar o almoço para todos. Neste mesmo período comecei a aprender violão e depois de ter feito a Crisma tornei-me professora de Catequese. Naquele tempo havia livros que orientavam as aulas e tinham as lições - tinha o mesmo livro para os professores de catequese e as crianças -, as quais preparava e uma vez por semana, durante uma hora e 30 minutos eu ministrava estas aulas. Nelas, para cantar com as crianças da catequese, levava sempre o meu violão, era sempre o momento melhor da aula quando cantávamos. Com isso algumas mães começaram a me solicitar que eu ensinasse seus filhos a tocar violão. Neste momento eu já não fazia mais aulas, pois a professora que me ensinou a tocar o básico passou a não mais prestar este serviço. Então, com quatorze/quinze anos de idade eu já tinha alunos de violão e ensinava-os num espaço de uma escola pública estadual de ensino fundamental, o que corresponde hoje aos anos finais. Para conseguir este lugar fui conversar com a direção da escola e eles me emprestaram: eu usava o espaço aos sábados a tarde e algumas tardes um lugar, que era uma sala de uma casa de madeira que pertencia à escola. A minha obrigação era deixar sempre tudo limpo e em ordem. Assim, todos os sábados e depois nos finais de tarde, ministrava aulas particulares de violão para crianças. Com o tempo fui convidada para dar aulas em outro município vizinho, e então ia aos sábados à tarde lá e durante a semana dava aula em minha cidade. Foi o meu primeiro trabalho como profissional da educação.

Posteriormente fiz o segundo grau, magistério na Escola Estadual Visconde de Cairú. Concluindo em julho de 1984, sendo que o estágio eu fiz na classe de alfabetização em que minha mãe era a professora regente.

Imediatamente iniciei a trabalhar em uma escola municipal da Ressaca do Guerrilha, que era exatamente igual aquela que fui iniciada com minha mãe, como regente de classe multisseriada. Aprendi muito! Trabalhei em com todas as turmas e iniciei o curso de Pedagogia habilitação para trabalhar com Deficientes Mentais na Universidade de Passo Fundo. Depois de pouco tempo, fui chamada para trabalhar na Apae e fiz concurso para atuar com docência nas escolas estaduais. Então, passei a trabalhar 40 horas na Apae como professora e psicopedagoga - responsável pela avaliação psicopedagógica das crianças - e 20h no Estado, como professora em classes de educação infantil, classe especial, classes do $1^{\circ}$ ao $4^{\circ}$ ano.

Neste período militava na Pastoral da Juventude - local, regional e estadual -, em espaços de liderança: organização dos festivais, jogos e o que mais gostava eram as formações. Era da equipe que aplicava o Treinamento de Agentes de Ação Pastoral Tapa - para jovens agricultores, o qual era replicado por meio do método do Jorge Boran: ver, julgar e agir. Trabalhava muito na comunidade com os grupos de jovens e com as

\begin{tabular}{|l|l|l|l|l|r|}
\hline Regae: Rev. Gest. Aval. Educ. & Santa Maria & v. 10 & N. especial & e67467, p. 1-60 & 2021
\end{tabular}


lideranças. Conheci e aprendi com muitas pessoas, sempre pautados em valores humanos de dignidade e liberdade. Deste grupo apoiávamos outros e participávamos do Sindicato dos Trabalhadores Rurais e dos movimentos dos jovens e das mulheres agricultoras. E, como filha de rotariano, também participava do Interact Club. Outro espaço que comecei a participar com nosso grupo de lideranças foi a política: no contexto dos anos 1980 com a abertura democrática, começamos a ter nossos candidatos a vereador, a deputados. Assim, logo conseguimos eleger o vice-prefeito na cidade de Tucunduva e, assim, do movimento pastoral fui entrando nos movimentos sociais até chegar ao político. Com os movimentos sociais que participei, me lembro que aprendi tantas coisas, a trabalhar em grupo, a viver e conviver com as diferenças, a doar-se sem esperar dos outros nada em troca.

No ano de 1987 tive a oportunidade e fortuna de encontrar o meu Maestro de Vida, Professor, Acadêmico Antonio Meneghetti. Neste período iniciei uma estrada que venho construindo até hoje que se interessa pelas minhas mais profundas verdades, aquelas que dizem respeito à busca da construção da projeção única que o ser fez em minha existência e que com a minha responsabilidade individual buscar compreender a mensagem e atuar dentro de mim mesma. O sentido é o encontro comigo, mas também com todos os viventes do mundo da vida. Esse ainda é contínuo aberto e com muito a percorrer.

Em 1988 conclui o curso de Pedagogia e iniciei a Especialização em Deficiência Mental, concluindo no ano de 1990, ano em que ingressei no Mestrado em Educação na Ufrgs, com proposta de pesquisa sobre dificuldades de aprendizagem. Ou seja, ao mesmo tempo em que cursava a graduação eu exercia a profissão docente. Meu sonho era estudar na UFSM, mas não seria possível, uma vez que não haveria condições de me manter estudando, porque o curso de Pedagogia era apenas diurno.

Com o final do curso de graduação entendi que estava na hora de começar uma nova estrada. Até então era profissional da educação, mas sentia que precisava aprender e estudar muito mais. Com a decisão de fazer o mestrado na Ufrgs, no final do ano de 1989, elaborei um projeto de pesquisa sobre as dificuldades de aprendizagem. Havia dez vagas de ingresso e 300 candidatos. Minha trajetória inserida nos movimentos sociais me dava uma visão de dificuldades de aprendizagem também vinculado aos problemas sociais. Desliguei-me do município no início do ano de 1990 para cursar o mestrado e, em abril, porque consegui bolsa do CNPq, me desliguei também das 20 horas que tinha como professora do Estado.

E foi no caminho da pesquisa que me encontrei com Henry Giroux e as racionalidades técnica, hermenêutica e emancipatória, as quais depois verificando em contextos de sala de aula e nas histórias de vida das pessoas, constrói os tecidos impermeáveis que moldam as condições sócio-históricas e limitam objetiva e subjetivamente o sucesso e o fracasso nos processos de aprendizagens. A pesquisa de mestrado foi intitulada $A$ produção social das dificuldades de aprendizagens: porque uma perspectiva não contemplada pelos grupos familiar e escolar.

No final de $1990 \mathrm{fiz}$ concurso público para professor do ensino superior no campus de Marechal Cândido Rondon, na Universidade Estadual do Oeste do Paraná - Unioeste para a vaga de Didática para os cursos de licenciatura História, Letras, Educação Física e Pedagogia. E, em 1991 iniciei minha carreira como professora universitária. Em dezembro

\begin{tabular}{|l|l|l|l|l|l|}
\hline Regae: Rev. Gest. Aval. Educ. & Santa Maria & v. 10 & N. especial & e67467, p. 1-60 & 2021
\end{tabular}


de 1992 defendi a dissertação de mestrado cujo título foi Produção das dificuldades de aprendizagem pelos grupos familiar e escolar, na qual, por meio da teoria crítica de Henry Giroux, encontrei fundamento para refletir a respeito dos problemas de aprendizagem, estudando casos de crianças que à época frequentavam as classes especiais. Neste ano já havia solicitado transferência para o campus de Toledo no qual, trabalhei no curso de licenciatura em Filosofia com todas as disciplinas didático-pedagógicas: História da Educação, Filosofia da Educação, Didática, Estrutura e Funcionamento do Ensino, Estágio Curricular.

Em Toledo muitas ocasiões de trabalhos aconteceram. Coordenei turmas de Estudos Adicionais ao Segundo Grau em Deficiência Mental, Auditiva, Visual e Física. Coordenei Especialização em Deficiência Mental, Especialização em Alfabetização, foram várias turmas. Neste período iniciei atender em clínica privada crianças com problemas de aprendizagem: permaneci nesta atividade durante 11 anos. $\mathrm{E}$ coordenei, junto à Coordenadoria de Educação de Toledo, a construção dos projetos político-pedagógicos na rede das escolas estaduais. Foi um trabalho que durou muito tempo e que me impulsionou à, no ano de 1994, iniciar o Doutorado em Educação na Unicamp: a proposta foi sobre a interdisciplinaridade na educação. Conclui o doutorado em dezembro de 1997. Em 1998 iniciei a trabalhar como docente, em Palmas no Paraná, e depois de um tempo também como coordenadora e pesquisadora do Mestrado em Educação nas Faculdades Integradas de Palmas, me desligando em 2004.

Neste período me dediquei muito ao trabalho na Clínica como Psicopedagoga. Atendia muitas crianças de classe média que apresentavam os clássicos problemas de aprendizagem. Minha abordagem, além de ser interdisciplinar e ter como pano de fundo a minha formação inicial, também utilizava a abordagem da Pedagogia Ontopsicológica. Organizei minha sala no prédio comercial da cidade e nos períodos em que não estava trabalhando na Unioeste atendia à pais e filhos. Buscava trabalhar sempre com pais, professores e outros profissionais - psicólogos, fonoaudiólogos, etc. -, equipes diretivas: coordenador e orientador pedagógico. Cada caso era tratado com máximo esmero e nunca realizando o trabalho apenas com a criança, mas sempre com todo o ecossistema de aprendizagem da criança. Esse trabalho fiz durante 11 anos.

\section{Percurso no Doutorado em Educação: metodologia}

Em meu doutorado fiz uma pesquisa sobre o modelo pedagógico piagetiano e montessoriano. Revisando a produção a respeito das discussões sobre a interdisciplinaridade e as propostas de Piaget e Montessori, elaborei novas compreensões sobre a aplicabilidade da interdisciplinaridade em campo pedagógico, ou seja, como seria a interdisciplinaridade no contexto das práticas pedagógicas. Foi importante identificar e conduzir a reconstrução dos fundamentos epistemológicos da pedagogia assim como das visões de Piaget e Montessori. A visão da formação do ser humano a partir de uma compreensão que remete a necessidade de encontrar e ao mesmo tempo cultivar no contexto das práticas, aquela forma humana que não se limita à divisão imposta pelo positivismo e cultivada ainda nas propostas pedagógicas escolares. Foi então que a pesquisa me conduziu a compreender que quem faz ciência é um pesquisador. A divisão da ciência revela a forma dividida da visão de ciência praticada. 
Logo, da mesma forma as práticas pedagógicas disciplinares expressam a mente disciplinarizada da formação dos professores, sobretudo dos pedagogos que contradizem com essa postura, a essência do fazer pedagógico, que perde sua razão de ser se não for interdisciplinar. Portanto, a pedagogia como praxiologia não pode não ser se não for interdisciplinar. Contudo, a própria visão de prática pedagógica e a formação do pedagogo deveria ser revisada por meio da radicalidade deste princípio que remete a globalidade e a complexidade do ato educativo. Além disso, a pedagogia, por sua própria especificidade, se constitui nas relações de transformações mútuas com outras áreas Filosofia, Psicologia, Sociologia, Antropologia, História, Artes, Educação Física, Biologia, Política, Arquitetura, Biblioteconomia, a tecnologia e assim tantas outras mais. Embora possua seu objeto de estudo, este estabelece relações de interdependência de mútua reciprocidade e sua evolução depende também, e não apenas, do grau de evolução e progressão dos avanços da epistemologia das Ciências Humanas.

Contudo, ainda hoje vivemos em um paradigma científico que é positivista, no qual, a subjetividade humana, a exemplo os protocolos de ética em pesquisa, consideram apenas o que é quantificável, assim como os processos de avaliação da aprendizagem, assim como tantos outros indicadores de 'qualidade' cujo princípio é mascarado pela quantidade, a exemplo da progressão docente: número de horas, número de produções, número de participações em bancas, etc. Os elementos constitutivos do ser humano, que são também o inconsciente humano, não são considerados, não porque não existem, mas porque ainda impera a visão de humano baseada nos elementos físicos e biológicos. As demais dimensões humanas que são as emoções, intuição, criatividade, etc. são pouco consideradas e muitas vezes até 'condenadas' e 'excluídas' dos protocolos e discussões da formação do pedagogo ou de pesquisas e processos de seleção e carreira do profissional da educação.

$\mathrm{E}$, foram as conclusões e inquietações da pesquisa de doutorado que me levaram a posteriormente àquela realizada por ocasião da especialização profissional em Psicologia realizada na Universidade Estatal de São Petersburgo na Rússia.

\section{Ingresso no PPGEd das Faculdades Integradas de Palmas e Centro Universitário Católico do Sudoeste do Paraná}

O aprendizado da pesquisa iniciado no doutorado foi logo exercitado durante o período de mestrado, orientando muitos alunos, trabalhando com as disciplinas de Metodologia de Pesquisa, coordenando grupo de pesquisa e desenvolvendo pesquisas. Além do trabalho na gestão - coordenação do Mestrado em Educação - também todas as atividades docentes e principalmente aquelas de pesquisa. Foi um período muito produtivo, porque tudo estava sendo criado na IES - dos regulamentos, aos grupos, às revistas etc. A IES ainda não possuía a cultura da pós-graduação e por consequência e da pesquisa científica.

No ano de 2000 me desliguei da Unioeste e fiz concurso na Univali, assumindo 40 horas, 20 na graduação em Pedagogia no campus de Meia Praia/ltapema e Itajaí, e 20 horas no Mestrado em Educação. Neste período, em Santa Catarina, iniciei a trabalhar como palestrante e docente em programas de formação de professores e ainda com assessoria as secretarias municipais de educação de Santa Catarina. Também iniciei um Programa de Formação para Professores Universitários Oficinas de Didática. No mesmo 
tempo trabalhei na Faculdade Sinergia, nos cursos de Administração e Pedagogia. Além disso, comecei a ministrar disciplinas em cursos de pós-graduação, todos os finais de semana, em SC, no PR e no RS.

Neste meu período me interessei muito sobre a formação dos professores sob a dimensão interdisciplinar. Compreendi que, de fato, o conhecimento, a competência técnica é fundamental, mas existe uma outra dimensão pouco explorada que é aquela da dimensão humana da formação docente, visto que, seu trabalho é com seres humanos, mediando aprendizagens.

Projeto: A percepção da formação profissional dos egressos do curso de pedagogia (2001-2002): este estudo objetivou identificar os problemas que os professores egressos, do curso de Pedagogia de uma IES, enfrentam relativos à sua formação profissional no exercício de sua atividade docente e que dizem respeito à percepção da sua formação universitária. Situação: concluído; Natureza: pesquisa. Alunos envolvidos: graduação; integrantes: Estela Maris Giordani - coordenador / Sonia Maria dos Santos da Silva integrante. Número de orientações: 1.

Projeto: O professor de ensino médio e o saber trabalhar em equipe (2001-2003): por meio desta pesquisa buscou-se investigar como os professores constroem e incorporam novos saberes à sua prática docente, mais especificamente o saber viver em conjunto. Isto porque encontram-se frente a um contexto paradoxal que apresenta transformações históricas, culturais, econômicas, tecnológicas e científicas ao mesmo tempo em que apresentam a incorporação de uma organização curricular conservadora e conformada com a realidade pseudoformadora existente no contexto educacional atual. Investigou-se como o professor constrói seus saberes na dialética com aqueles que interagem no contexto pedagógico. O trabalhar em equipe é uma das competências prioritárias, conforme Perrenoud (2000), que constitui o saber ensinar e o novo papel dos professores compatível com os eixos de renovação da escola. Essa pesquisa também buscou identificar como os professores constroem esta convivência grupal necessária para atender a uma nova perspectiva paradigmática que traz consigo uma nova forma de pensar e viver a realidade escolar. Esta perspectiva paradigmática, por sua vez, implica numa mudança na formação profissional dos docentes - inicial ou continuada -, na forma como concebem e concretizam sua prática pedagógica. Situação: concluído. Alunos envolvidos: graduação: (2) / Mestrado acadêmico: (1) Integrantes: Estela Maris Giordani coordenador. Número de produções C, T \& A: 13 / Número de orientações: 3.

Projeto: Interdisciplinaridade em práticas pedagógicas (2001-2004): a pesquisa consistiu em verificar quais são as dificuldades enfrentadas por professores que atuam no ensino de $2^{\circ}$ grau, para implementar práticas interdisciplinares e, se o modelo para captar a dimensão interdisciplinar de práticas pedagógicas desenvolvido por Giordani (2000) é capaz de fazê-lo e, se não, quais seus problemas e/ou como poderia ser ele reestruturado. A pesquisa compreendeu duas etapas a serem realizadas concomitantemente: 1) a primeira etapa consistiu verificar quais são as principais dificuldades enfrentadas para implementação de práticas interdisciplinares e porque elas surgem, levando em consideração os diferentes aspectos implicados nesta prática; 2) a segunda etapa consistiu em verificar se as práticas que se propõem interdisciplinares 
podem ser consideradas interdisciplinares ou não, segundo o modelo desenvolvido por Giordani (2000). Situação: concluído; Natureza: pesquisa. Alunos envolvidos: graduação: (2). Integrantes: Estela Maris Giordani - coordenador / Aline Martins Rospa - integrante. Número de produções C, T \& A: 55. Número de orientações: 9.

Projeto: Os professores dos cursos de licenciatura e a competência de administrar sua formação contínua (2002-2004): esta pesquisa visou a verificar como os professores dos cursos de licenciatura gerenciam sua formação continuada. O objetivo foi o de verificar quais são as estratégias que estes profissionais escolhem e utilizam para manterem-se atualizados. Assim sendo, considera-se que este profissional possa criar sua própria forma de constante aprimoramento profissional. Trata-se também de perceber se, ao administrar sua formação, em suas estratégias, que competências privilegiam ou incluem ou pouco privilegiam. Situação: concluído; Natureza: pesquisa. Alunos envolvidos: graduação: (1). Integrantes: Estela Maris Giordani - coordenador / Amândia Coelho - integrante. Número de produções C, T \& A: 46 / Número de orientações: 2.

Projeto: Aprendizagens da avaliação (2002 - 2004): este estudo se propôs a verificar como os alunos do ensino fundamental incorporam as práticas de avaliação escolares. Percebeu-se o processo de avaliação que o aluno vivencia o auxilia como feedback de sua aprendizagem ou se incorpora através dessa uma outra aprendizagem não prevista. A avaliação, neste entendimento, não possui caráter classificatório, mas, de aprendizagem. Este estudo vai investigar como os alunos incorporam as práticas avaliativas e quais os resultados em relação ao processo de aprendizagem, isto é, que aprendizagens o processo de avaliação - considerando a prática de avaliação adotada pelo professor e vivenciada pelo aluno - propicia ao aluno? A metodologia utilizada para desenvolver a pesquisa foi de abordagem qualitativa e como amostragem trabalhou com alunos de uma escola de ensino fundamental do município de Itapema que possui proposta inovadora de avaliação da aprendizagem. Foi aplicada a técnica do desenho espontâneo da criança a partir do tema avaliação, a partir da expressão simbólica livre, pode-se chegar aos resultados desta pesquisa. Verificou-se como resultado que no processo de avaliação desenvolvido pela escola ocorre um universo de significados que ultrapassam intencionalidades explícitas pelo professor. A forma espontânea da criança em manifestar estes conhecimentos, habilidades, hábitos e atitudes, sobre essa ação que pode levar a repensar a visão que se possui de aprendizagem e da avaliação. Situação: Concluído; Natureza: pesquisa. Alunos envolvidos: graduação: (1) / Especialização: (1). Integrantes: Estela Maris Giordani - coordenador / Jaqueline Cardoso de Lima integrante. Financiador: Governo de Santa Catarina - bolsa. Número de produções C, T \& A: 5 / Número de orientações: 2.

Publicação: GIORDANI, Estela M. A docência como ato de inteligência e a formação do professor universitário. FÓRUM DE ENSINO SUPERIOR DO SUDOESTE DO PARANÁ E OESTE DE SANTA CATARINA, 1, 2002. Anais ... Pato Branco: Cefeti/PR; Fundação Araucária, 2002, p. 54-59.

Neste período a minha principal aprendizagem foi ter bolsista de iniciação, realizar a orientação de trabalhos de iniciação científica, desenvolver pesquisas e organizar e coordenar grupos de estudo e de pesquisas na Unics e na Univali. 
Este período foi fundamental porque aprendi importantes lições. Foi a primeira vez que ministrei disciplina em mestrado acadêmico. E o que mais me chamou atenção foi que os alunos não tinham disciplina de estudo e nem tão pouco sabiam ler um texto academicamente. Foi então que desenvolvi uma das metodologias mais importantes que fiz em minha carreira que foi estruturar um método de leitura o qual denominei de Leitura inteligente e que só vim a formalizar, estudar, verificar a eficiência desta técnica em minhas pesquisas na UFSM com as atividades de orientação de estágio.

\section{Especialização Profissional em Psicologia com abordagem em Ontopsicologia}

Entre os anos de 2000 e 2003 realizei o curso de Especialização Profissional em Psicologia com abordagem em Ontopsicologia, com 684 horas, na Universidade Estatal de São Petersburgo ${ }^{2}$ - SPbU/RU.

Figura 1 -

Universidade Estatal de São Petersburgo.

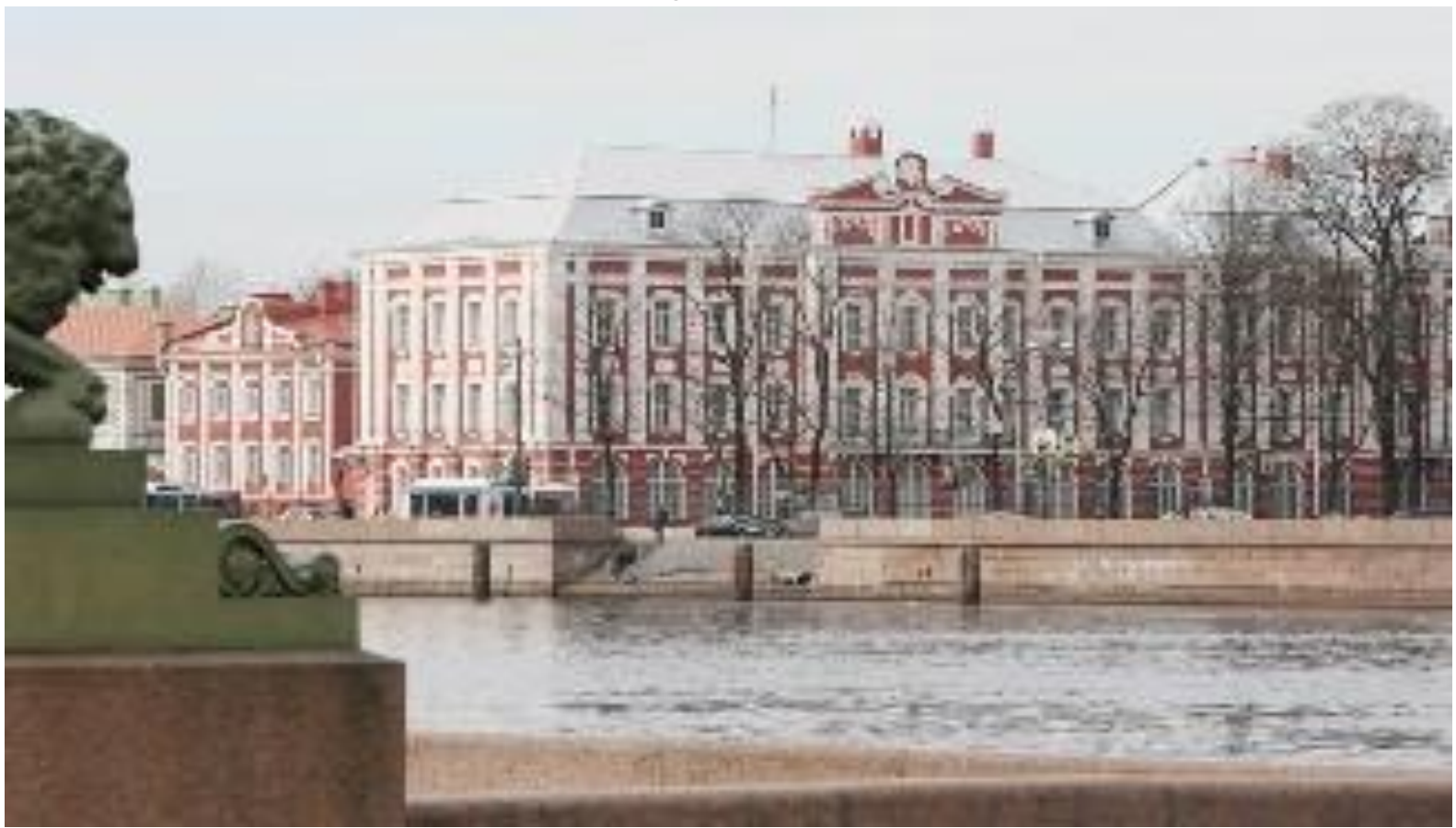

Fonte: $\underline{\text { https://spbu.ru/. }}$

Foi uma das experiências mais difíceis da minha vida, porque além de possuir as dificuldades de língua e cultura que eram completamente diversas, a tipologia de racionalidade científica e o estilo de relação professor-aluno e conhecimento foram

\footnotetext{
${ }^{2}$ Fundada pelo czar Pedro I, em 1724, teve a czarina Catarina, a Grande, como a sua primeira reitora. A Universidade Estatal de São Petersburgo é uma importante instituição da Rússia, conhecida pela excelência de suas pesquisas e ensino. Ela oferece 106 graduações e 205 mestrados e tem parcerias com 350 universidades internacionais. A SPbU recebe estudantes estrangeiros de mais de 70 países e já formou inúmeros acadêmicos extraordinários e nove vencedores do Prêmio Nobel. Disponível em https://www.hotcourses.com.br/study/russia/school-college-university/saint-petersburg-stateuniversity/419010/international.html. Acesso em 10 de maio 2020.

\begin{tabular}{|l|l|l|l|l|}
\hline Regae: Rev. Gest. Aval. Educ. & Santa Maria & v. 10 & N. especial & e67467, p. 1-60
\end{tabular}
}


seguramente as coisas que mais me desestruturam. Esta aprendizagem me fez mudar muito das minhas certezas pedagógicas, pois convivi com paradoxos que considerava impossíveis de serem conciliados e contradições de valores pedagógicos que imaginava absolutos.

Aparentemente poderiam remeter a isso, mas analisando com mais seriedade por mim, considerando também meu preparo em âmbito pedagógico, não houve como não desmentir aquelas compreensões que possuía pautadas essencialmente em ideários e crenças e muito pouco em evidências. A ponto de suspeitar que todo meu preparo em campo pedagógico havia ruído. $\mathrm{E}$ me vi despida diante de preconceitos que acreditava serem compreensões. Foi uma dura escola! Mas vamos com calma, a complexidade é grande! Não saberia de fato por onde começar ... trarei aqui a minha percepção, o quanto eu me impactei, o quanto sofri, porque desaprender é mais difícil do que aprender. Essa foi uma grande oportunidade de renascer a partir de referências diversas daquelas minhas pseudo-verdades.

Sobre as características do povo russo também houve a mesma sensação de estar descalça, pois aquela visão que tinha sobre eles e que havia sido construída por meio da cultura midiática, preponderantemente da cultura do cinema americano, não se verificava no impacto direto com aquela cultura. Ao invés disso encontrei um povo muito rico em vários sentidos, inclusive economicamente, culto, rico, humano, solidário, inteligente, gentil, amoroso, tranquilo, elegante, refinadíssimo, com menores diferenças sociais em relação ao Brasil. O imperialismo americano nunca conseguiu penetrar lá, então, não foi ao acaso que como colônia cultural construímos uma visão de que eram os 'bandidos' da história.

Percebia do ponto de vista intelectual e cultural que existia uma enorme distância entre um russo e um brasileiro - por exemplo, era comum encontrar cidadãos que falassem pelo menos três línguas - russo, inglês, alemão/francês - mas geralmente outra língua dialeto os dos povos do norte europeu. $E$ havia algo que me conectava imediatamente a eles! Depois do primeiro impacto da frieza racional, abria-se o calor da viva alma alegre e doce daquele povo e eu não conseguiria identificar se estava interagindo com um russo ou um brasileiro. Sentia no fundo que um russo possui muitas semelhanças com o espírito do povo brasileiro. De fato, são um povo muito humano, quando impactados a partir de seu íntimo se parecem muito conosco, com o povo brasileiro: se superada a camada de gelo que esconde o coração quente e pulsante do povo russo. Nas ruas percebia, conversando com as pessoas sobre os índices de desemprego e pobreza e por diversas vezes e em ocasiões diferentes, manifestavam essa mesma informação.

Nossa sala de aula, na Universidade Estatal de São Petersburgo, Faculdade de Psicologia, estava a dois andares acima do Laboratório de Reflexologia de Ivan Pavlov e, das janelas amplas, podíamos ver ao lado o Rio Neva e, na margem diagonal oposta de onde estávamos, o majestoso Museu Hermitage, antigo Palácio de Pedro, o Grande.

A Universidade Estatal de São Petersburgo teve duas reitoras: Catarina, a Grande, e depois Ludimila Verbiskaya, excepcional personalidade de ciência, cultura e diplomacia que faleceu ano passado. E se orgulha de ser a universidade que formou grandes diplomatas, estadistas, cientistas. 
São Petersburgo é uma cidade que possui mais de 300 canais fluviais, inspirada em Veneza mas infinitamente mais elegante e exuberante. Os principais hotéis nas refeições principais tinham música clássica ao vivo. Inúmeras peças de teatro, óperas, balés, shows, museus, cafés literários ... enfim!

A disciplina de estudos, a vivência em uma cultura de grandes riquezas culturais e econômicas, somadas à sua história e ao mesmo tempo a enorme diferença do modo de pesquisa e de docência me fizeram aprender muito. Como uma universidade europeia 0 professor entra em sala de aula para expor sínteses elaboradas, as quais, para serem compreendidas dependem do empenho de estudo dos alunos, sendo que a aula dura no máximo duas horas, também possui a sequência da exposição e abertura para perguntas e esclarecimentos. Mas sempre muito prática, pois os professores ensinam o que fazem, então, não apenas sabem os princípios teóricos de memória, mas os vivem em suas práticas de pesquisa. O professor catedrático conduz suas pesquisas com outros professores aprendizes os quais vai sendo formado juntamente com ele no contexto da pesquisa e docência. Os conteúdos curriculares da formação que recebemos partem das problemáticas das pesquisas desenvolvidas na Cátedra as quais derivam de demandas sociais concretas.

Ou seja, a pesquisa que os docentes realizam são aquelas que diferentes setores sociais requisitam para portarem compreensões e ao mesmo tempo soluções concretas e melhorias das condições de vida. Desta forma, são conciliados os interesses dos professores e aquelas das demandas sócio históricas. Esta característica torna o ensino pautado sobre as pesquisas desenvolvidas e para mim, que era estudante ao mesmo tempo em que se tornava muito mais interessante, conseguia vislumbrar a aplicabilidade do conhecimento em situações reais e concretas para a melhoria das condições de vida humana em sociedade. De forma que entre sociedade e ciência exista uma relação dialética de colaboração. Portanto, a pesquisa também é desejada e financiada pela sociedade. E esta relação aumentava a responsabilidade e ao mesmo tempo o valor da pesquisa e da ciência no contexto social.

Figura 2 -

Associação Eslava de Ontopsicologia - ASO - 8 out. 2001.

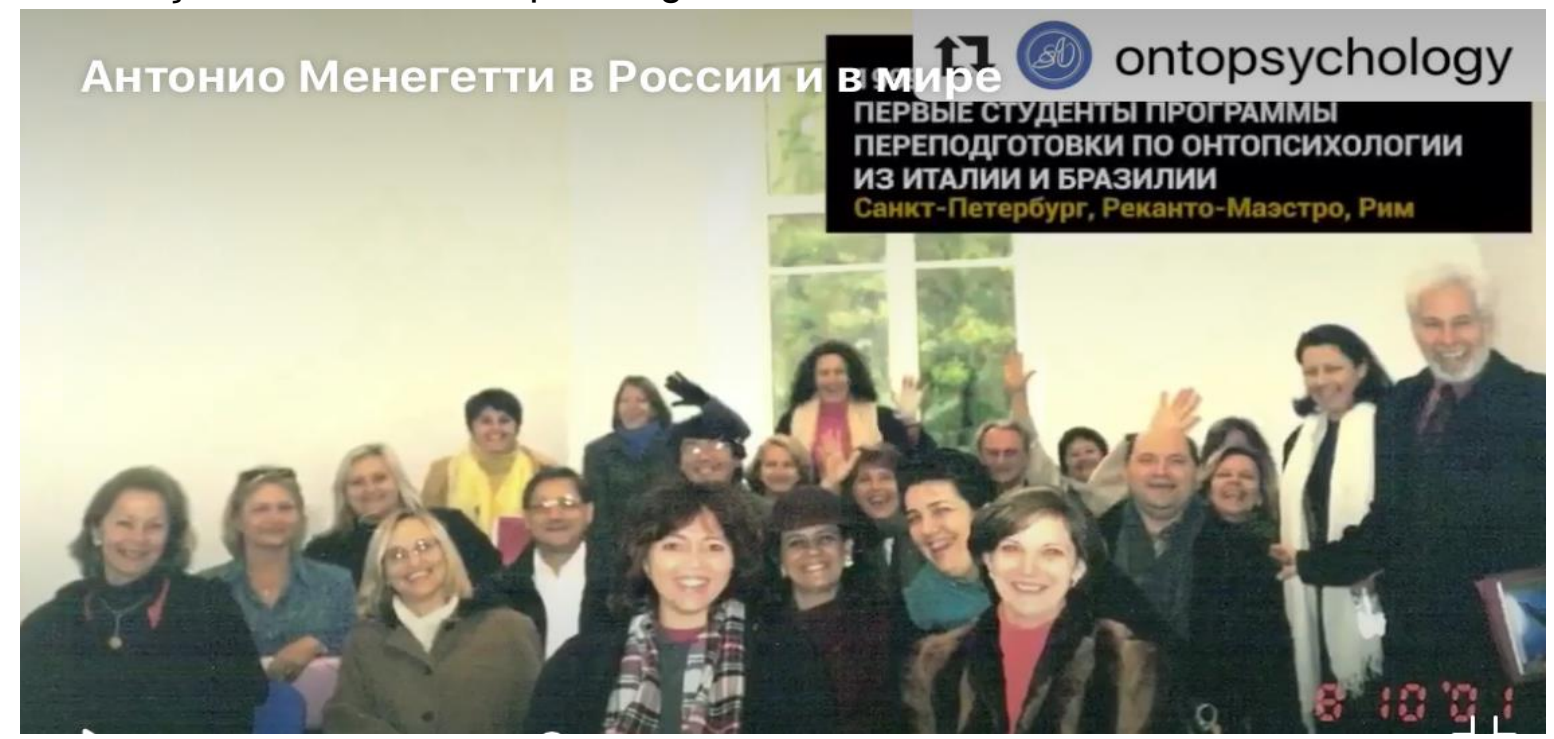

Fonte: arquivo pessoal. Apareço ao fundo com cabelo curto de lenço amarelo e casaco cor creme. Santa Maria v. 10 N. especial e67467, p. 1-60 2021 
A pesquisa que desenvolvi foi sobre as particularidades da visão de 'eu real e ideal' de professores universitários dos cursos de Direito, Administração e Pedagogia e a importância da revisão crítica da consciência dos professores universitários. O título da pesquisa: $A$ percepção dos componentes profissionalmente significativas da imagem dos professores universitários nos sujeitos do processo de ensino universitário.

As conclusões da pesquisa que desenvolvi indicaram-me elementos interessantes que podem ser considerados nos contextos de formação dos profissionais no ensino superior, mas especialmente nos pedagogos. As conclusões da pesquisa demonstraram, embora não definitivamente, que entre os docentes dos cursos existe um 'modo de ser' que constitui aquele perfil profissional que o corpo docente comunica o qual é percebido e aprendido pelos alunos. Ou seja, os professores não ensinam apenas os conteúdos teórico-práticos, enquanto ensinam informam aqueles valores e atitudes que constituem o modo de ser daquele perfil profissional. Isso inclui, tanto os elementos subjetivos necessários, quanto aquelas estereotipias que podem portar ao desempenho profissional atitudes contraditórias á ética do exercício da sua função. Um exemplo muito típico no campo da educação é a formação do pedagogo que é afetuoso mas que esse perfil, em seu estremo pode gerar problemáticas de relação professor-aluno próximas ao papel paterno ou materno, o qual, não é desejado, embora a relação afetuosa seja muito importante na relação professor-aluno, especialmente em se tratando da educação infantil e anos iniciais do ensino fundamental.

Figura 3 -

Certificação de conclusão do curso Especialização Profissional em Psicologia com abordagem em Ontopsicologia.

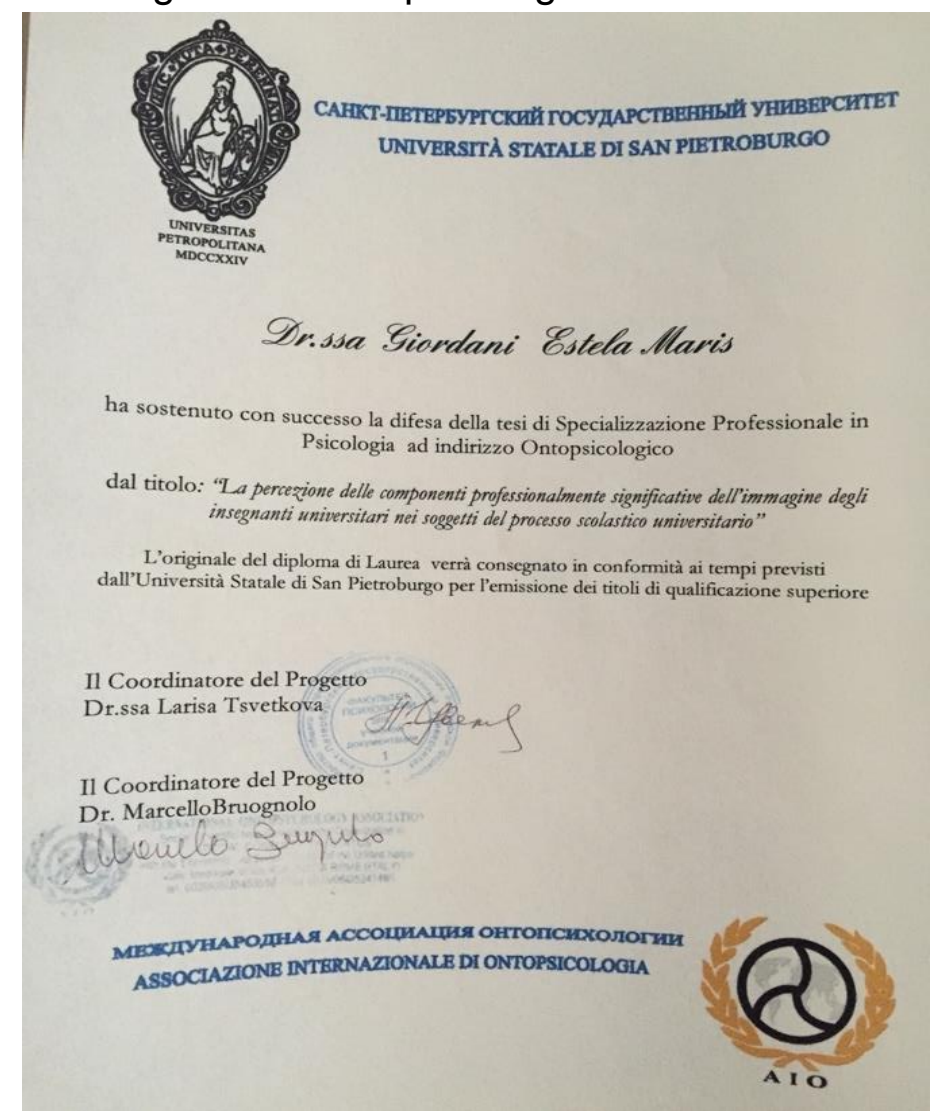

Fonte: arquivo pessoal. 
Por meio da pesquisa foi possível também perceber que os professores que desenvolviam um percurso de revisão do seu 'eu', conseguiam relativizar o perfil profissional de forma a conseguirem nos processos de ensino-aprendizagem manifestar com seus estudantes uma visão de 'eu real e ideal' mais próximas - percepção do professor e do aluno sobre o 'eu real e o ideal' do professor - do que aqueles professores que não possuíam o hábito de rever a sua visão mediante a psicoterapia. Deste modo, a pesquisa, embora não conclusiva e exaustiva levou a compreender que a visão que o professor possui de si mesmo, no confronto consigo e com seus alunos repercute no processo de formação profissional dos acadêmicos. Esta pesquisa me levou a refletir sobre a interferência da pessoa do professor na formação profissional do estudante universitário. $\mathrm{E}$, de forma mais humilde e sistemática, a investir seriamente na minha formação integral, não apenas na minha formação intelectual, mas na compreensão das minhas emoções e da construção da própria consciência. Neste estudo, dei-me conta e evidenciei que a construção do meu 'eu' - assim como o 'eu' de todo ser humano - teve como referência única o mundo externo - os afetos e valores da família, do grupo social sem qualquer referência construída a partir do próprio íntimo, da inteligência nativa e dos valores que por capacidade e intencionalidade da vida cada ser humano possui dentro de si. Portanto, grande parte do que reputamos por 'eu', não é nada mais do que o modo que subjetivamente o indivíduo construiu para responder ao superego do grupo, deixando para trás todo o enorme recurso que possui dentro de si para por em ato aquilo que cada um é, por intencionalidade da vida.

Contudo, a defesa da tese era apenas a primeira etapa da formação. Era necessário passar pelo exame teórico-existencial. Este foi o mais difícil de todos, pois, assim como nossos professores, teríamos que ter o domínio fluente da teoria aplicada em nossa vida, pois, afinal de contas, tratava-se de um curso de Psicologia e o exame existencial, a aplicabilidade nas mudanças em nossa vida era requisito indispensável. Cheguei a ponto de pensar que não seria capaz, depois me empenhei e consegui lograr nota máxima nesta prova, depois de ter reprovado na minha primeira tentativa. Neste percurso fiz muitas descobertas, dentre as quais muito interessantes que mudaram profundamente a compreensão que possuía sobre as aprendizagens. Embora ainda hoje continuamente me dedico a compreender mais sobre a relação aprender e o papel do professor.

A pesquisa em Ontopsicologia prosseguiu e, assim, com quadro que pode ser visto no link ${ }^{3}$ entende-se minha atuação e contribuição para o desenvolvimento desta ciência. Também atuo como integrante do Conselho Científico da Associação Brasileira de Ontopsicologia, desde 2006 até os dias atuais.

\section{UFSM: uma nova etapa de vida}

Em 2003 fiz dois concursos na UFSM, um para vaga de professor de Políticas Públicas no ADE, ficando em terceiro lugar, e no MEN, na vaga de Didática e Prática de Ensino, ficando em primeiro lugar. Assumi a vaga do MEN em 23 de julho de 2004. Finalmente, aos 38 anos, voltei para casa! E de 2004 até a presente data \#SOUUFSM.

\footnotetext{
${ }^{3}$ https://www.fundacaoam.org.br/Content/docs/publicacoes/Pesquisa em Ontopsicologia no Brasil revisada 18.11.19.pdf. \begin{tabular}{|l|l|l|l|l|l|}
\hline Regae: Rev. Gest. Aval. Educ. & Santa Maria & v. 10 & N. especial & e67467, p. 1-60 & 2021
\end{tabular}
} 
A seguir estão descritas as disciplinas ministradas do segundo semestre de 2004 até o ano de 2008, visto que depois as apresento mais detalhadamente, tendo em vista o memorial dos últimos dez anos. Foram muitos desafios, visto que, embora já tivesse atuado no curso de Pedagogia, eu agora começava uma nova estrada desafiadora que foi os estágios. De fato, nesta me identifiquei muito.

Figura 4 -

Encargos didáticos no segundo semestre de 2004: 856 horas aula.

Encargo didático

\begin{tabular}{|c|c|c|c|c|}
\hline & ₹ Turma & ٪ Disciplina & F Curso & - Encargo didático (h) \\
\hline - & 11 & MEN415 - DIDATICA II & $\begin{array}{l}\text { Pedagogia - Magistério - Educaçăo Pré- } \\
\text { Escolar - } 621\end{array}$ & 105 \\
\hline - & 01 & MEN415 - DIDATICA II & $\begin{array}{l}\text { Pedagogia - Magistério Séries Iniciais - } \\
622\end{array}$ & 105 \\
\hline - & 12 & MEN415 - DIDATICA II & $\begin{array}{l}\text { Pedagogia - Magistério Séries Iniciais - } \\
622\end{array}$ & 105 \\
\hline - & 02 & $\begin{array}{l}\text { MENA25 - PRATICA DE ENS.NA ESCOLA } \\
\text { DE II GRAU }\end{array}$ & $\begin{array}{l}\text { Pedagogia - Magistério - Educação Pré- } \\
\text { Escolar - } 621\end{array}$ & 90 \\
\hline - & 12 & $\begin{array}{l}\text { MENA25 - PRATICA DE ENS.NA ESCOLA } \\
\text { DE II GRAU }\end{array}$ & $\begin{array}{l}\text { Pedagogia - Magistério - Educação Pré- } \\
\text { Escolar - } 621\end{array}$ & 90 \\
\hline - & 11 & $\begin{array}{l}\text { MEN425 - PRATICA DE ENS.NA ESCOLA } \\
\text { DE II GRAU }\end{array}$ & $\begin{array}{l}\text { Pedagogia - Magistério - Educação Pré- } \\
\text { Escolar - } 621\end{array}$ & 90 \\
\hline - & 01 & $\begin{array}{l}\text { MENA25 - PRATICA DE ENS.NA ESCOLA } \\
\text { DE II GRAU }\end{array}$ & $\begin{array}{l}\text { Pedagogia - Magistério Séries Iniciais - } \\
622\end{array}$ & 90 \\
\hline - & 12 & $\begin{array}{l}\text { MEN419 - PRÁTICA DE ENSINO NA } \\
\text { ESCOLA DE } 1 \text { GRAU }\end{array}$ & $\begin{array}{l}\text { Pedagogia - Magistério - Educaçăo Pré- } \\
\text { Escolar - } 621\end{array}$ & 90 \\
\hline - & 11 & $\begin{array}{l}\text { MEN } 419 \text { - PRÁTICA DE ENSINO NA } \\
\text { ESCOLA DE } 1 \text { GRAU }\end{array}$ & $\begin{array}{l}\text { Pedagogia - Magistério - Educação Pré- } \\
\text { Escolar - } 621\end{array}$ & 90 \\
\hline \multicolumn{4}{|c|}{ Encargo didático total: } & 855 \\
\hline \multicolumn{5}{|c|}{ Aviso } \\
\hline
\end{tabular}

Q Imprimir

Fonte: Portal do professor/UFSM.

Neste mesmo ano também desenvolvi as seguintes atividades de pesquisa e extensão.

Projetos de extensão 2004:

a) Registro GAP/CE 016461: Diálogo entre formação inicial e continuada de professores na prática de ensino escolar - período 01/09/2004 a 31/12/2004. Função: participante.

b) Registro GAP/CE 016615: Oficinas de didática - período 15/10/2004 a 15/02/2007. Função: coordenação.

\section{Projetos de pesquisa 2004}

- Registro GAP/CE 016665: Formação profissional no ensino superior e atuação docente - Período: 20/09/2004 a 20/12/2006. Função: coordenadora.

- Registro GAP/CE 016664: A docência em construção: uma abordagem interdisciplinar - Período: 20/09/2004 a 20/12/2006. Função: coordenadora.

- A docência em construção: uma abordagem interdisciplinar (2004-2006): no atual contexto do ensino é crescente a preocupação com o significado da figura do professor. A aprendizagem da docência em geral é marcada por variáveis nem sempre previstas ou consideradas no momento da formação e atuação do professor. Através da filmagem da atividade de extensão das Oficinas de Didática serão oportunizadas aos professores outras experiências, alargando suas possibilidades em relação aos processos de ensino- 
aprendizagem. Trata-se de uma investigação de uma metodologia de formação contínua de professores do ensino superior cuja perspectiva é interdisciplinar. Busca-se investigar como o processo de construção da docência ocorre com um instrumento que oportuniza a dialética viva do feedback produzido pelas filmagens. Busca-se verificar se esta metodologia de formação contínua conduz a processos de mudanças em práticas pedagógicas dos professores no sentido de explicitar a repercussão dessa metodologia de formação nas práticas pedagógicas. Busca-se elucidar os processos de aprendizagem da docência no sentido de trabalhar as percepções pré-conceitos, noções e concepções da sua prática. Este processo implica em confrontar o ideal profissional com 0 real exercido construindo uma identidade profissional cujo eixo articulador seja o processo de desconstrução - reconstrução de suas competências profissionais enquanto aprendiz em ofício/exercício ou em oficina. Palavras-chave: didática, interdisciplinaridade, formação docente. Situação: Em andamento; Natureza: pesquisa. Alunos envolvidos: graduação: (4) / Especialização: (0) / Mestrado acadêmico: (0) / Mestrado profissional: (0) / Doutorado: (0) Integrantes: Estela Maris Giordani - coordenador / Endrigo Corso Longhi integrante / Marilisa Zibetti - integrante / Greice Scremin - Integrante / Jaqueline Chassot integrante. Financiador(es): Fundação de Amparo à Pesquisa do Estado do Rio Grande do Sul - bolsa / UFSM - bolsa / Fundação Instituto de Pesquisas Econômicas - bolsa. Número de produções C, T \& A: 20 / Número de orientações: 6

Pesquisa formação profissional no ensino superior e atuação docente (2004-2006): pesquisar a docência no ensino superior supõem um intrínseco refletir sobre a formação profissional que se faz neste nível. Assim, quando se fala de formação no ensino superior não se pensa apenas no ato estrito da docência, mas, sobretudo, em todos os processos que exigem o pensar de um profissional numa sociedade complexa e globalizada. Um dos processos de acompanhamento por parte do MEC sobre a formação desenvolvida no ensino superior é o provão. Além desse, a Instituição de Ensino Superior deve fazer a avaliação institucional. Cada instituição desenvolve ao seu modo este processo assim como os seus programas de capacitação docente através dos Planos de Carreira ou das Políticas adotadas pelas administrações. A avaliação institucional avalia muitos aspectos, dentre os quais o aluno avalia seus professores. Neste sentido, este projeto busca fazer uma análise qualitativa partindo dos resultados da avaliação do desempenho docente por parte dos alunos a fim de verificar a percepção que estes possuem sobre a capacitação de seus docentes, sua formação e relação com a influência que exercem durante a realização do curso superior. Alguns docentes em sua prática no ensino superior têm levado em consideração o feedback dos seus alunos (ver em GIORDANI e COELHO, 2002). Trata-se de perceber através de análise qualitativa, através de entrevistas gravadas com alunos se e como a formação do professor se torna vivenciada no processo de formação profissional dos acadêmicos. Toma-se a percepção do discente porque se entende que ele também é responsável por sua formação profissional bem como, entende-se que ele faz parte do sucesso da carreira do docente, pois o sentido que os entrevistados manifestaram em nossas pesquisas anteriores foi exatamente ser 0 aluno um dos principais motivos de sua qualificação profissional. Situação: concluído; Natureza: pesquisa. Alunos envolvidos: Graduação: (4) / Especialização: (0) / Mestrado acadêmico: (0) / Mestrado profissional: (0) / Doutorado: (0). Integrantes: Estela Maris Giordani - 
coordenador / Patrícia Ketzer - Integrante / Cecília Machado Henriques - Integrante / Aline Tamires Kroetz - Integrante / Aline Simone Holzschuh - Integrante. Número de produções C, T \& A: 3 / Número de orientações: 3

Além das atividades de ensino e das pesquisas, minhas primeiras preocupações na UFSM foram focadas também em projetos de extensão universitária. Trabalhei nos anos de 2005-2006 com cinco projetos concomitantemente. Mas os que eu mais gostava eram os de Oficina de didática e o Oficina de aprendizagem básica de pesquisa.

Figura 5 -

Encargos didáticos no primeiro semestre de 2005: 570 horas aula.

Encargo didático

\begin{tabular}{|c|c|c|c|c|}
\hline & - Turma & - Disciplina & F Curso & - Encargo didático (h) \\
\hline- & 01 & MEN415 - DIDATICA II & $\begin{array}{l}\text { Pedagogia - Magistério - } \\
\text { Educaçẫo Pré-Escolar - } 621\end{array}$ & 105 \\
\hline- & 11 & MEN415 - DIDATICA II & $\begin{array}{l}\text { Pedagogia - Magistério - } \\
\text { Educaçăo Pré-Escolar - } 621\end{array}$ & 105 \\
\hline- & 11 & $\begin{array}{l}\text { MEN1008 - DIDÁTICA EM } \\
\text { FILOSOFIA }\end{array}$ & $\begin{array}{l}\text { Filosofia - Licenciatura Plena - } \\
101\end{array}$ & 60 \\
\hline- & 10 & $\begin{array}{l}\text { MEN853 - METODOLOGIA DO } \\
\text { ENSINO }\end{array}$ & $\begin{array}{l}\text { PG em Geomática - } \\
\text { Especialização - } 897\end{array}$ & 60 \\
\hline- & 10 & $\begin{array}{l}\text { MEN704 - METODOLOGIA DO } \\
\text { ENSINO SUPERIOR }\end{array}$ & $\begin{array}{l}\text { PG Geociências - Especialização } \\
-981\end{array}$ & 60 \\
\hline- & 15 & $\begin{array}{l}\text { MEN425 - PRATICA DE ENS.NA } \\
\text { ESCOLA DE ॥ GRAU }\end{array}$ & $\begin{array}{l}\text { Pedagogia - Magistério - } \\
\text { Educaçẫo Pré-Escolar - } 621\end{array}$ & 0 \\
\hline- & 15 & $\begin{array}{l}\text { MEN425 - PRATICA DE ENS.NA } \\
\text { ESCOLA DE ॥ GRAU }\end{array}$ & $\begin{array}{l}\text { Pedagogia - Magistério Séries } \\
\text { Iniciais - } 622\end{array}$ & 0 \\
\hline- & 03 & $\begin{array}{l}\text { MEN425 - PRATICA DE ENS.NA } \\
\text { ESCOLA DE II GRAU }\end{array}$ & $\begin{array}{l}\text { Pedagogia - Magistério Séries } \\
\text { Iniciais - } 622\end{array}$ & 90 \\
\hline- & 01 & $\begin{array}{l}\text { MEN419 - PRÁTICA DE ENSINO } \\
\text { NA ESCOLA DE } 1 \text { GRAU }\end{array}$ & $\begin{array}{l}\text { Pedagogia - Magistério - } \\
\text { Educação Pré-Escolar - } 621\end{array}$ & 90 \\
\hline
\end{tabular}

Aviso

Turmas de cursos EaD ou sem alunos, não contabilizam encargo didático.

O Imprimir

Portal do professor - Versão 2.2.26

Fonte: Portal do professor/UFSM.

Figura 6 -

Encargos didáticos no segundo semestre de 2005: 570 horas aula.

\section{Encargo didático}

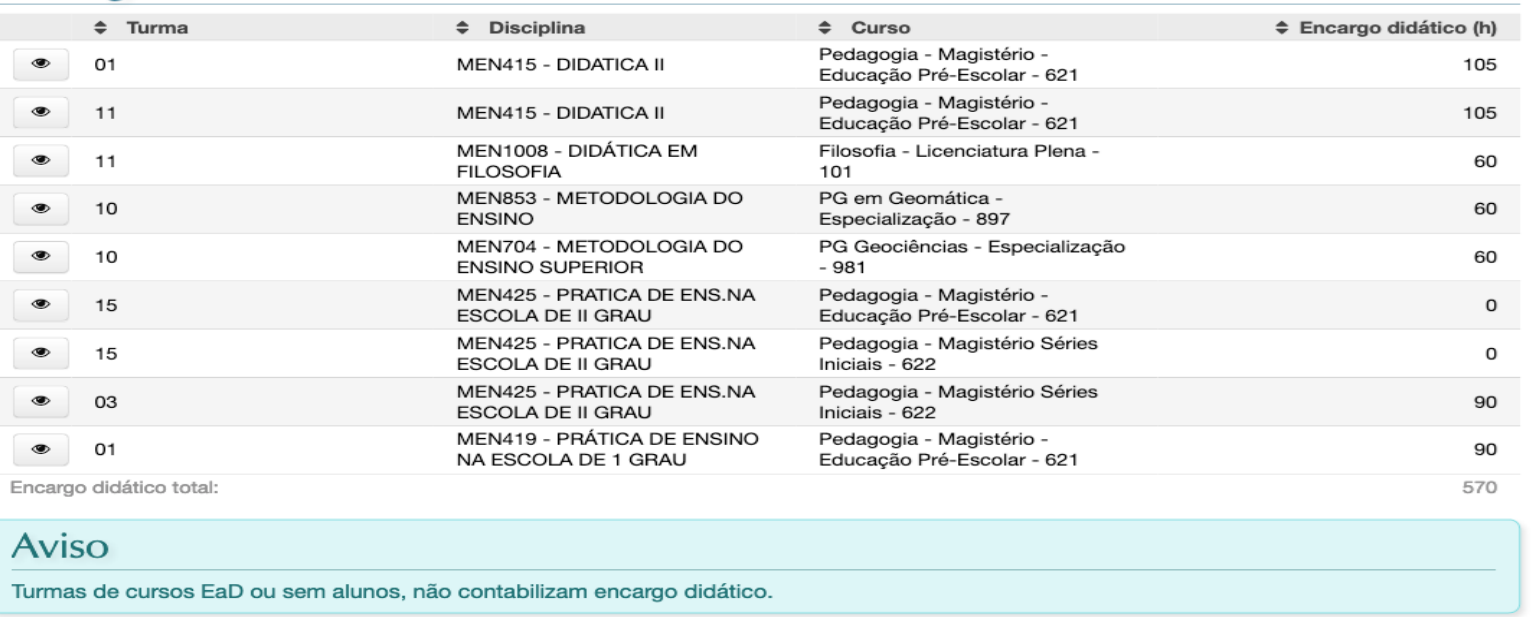

Fonte: Portal do professor/UFSM. 
Projetos de extensão em 2005

a) Registro GAP/CE 017351 - Oficinas de didática - Período: 03/05/2005 a 20/12/2005. Função: coordenação.

b) Registro GAP/CE 017355 - oficinas: aquisição de habilidades básicas em pesquisa - Período: 03/05/2005 a 20/12/2005. Função: coordenação.

c) Registro GAP/CE 017369 - Atividade complementar de pós-graduação do curso de especialização em educação num enfoque globalizador - didática numa perspectiva multidimensional - Período: 16/05/2005 a 16/05/2005. Função: coordenação.

d) Registro GAP/CE 017692 - Curso de formação continuada no instituto Estadual Olavo Bilac - ação Prodepd - Período: 03/05/2005 a 30/12/2006. Função: participante

e) Registro GAP/CE 017370 - Psicologia educacional: questões metodológicas e teórico-práticas - Período: 10/08/2005 a 14/09/2005. Função: participante

f) Registro GAP/CE 017773 - II Seminário sobre Estágios Curriculares Supervisionados: enfrentando os desafios formativos - Período: 15/05/2005 a 15/07/2005. Função: colaborador.

\section{Projetos de ensino em 2005}

- Registro GAP/CE 017677 - Curso de capacitação de servidores técnicoadministrativos do serviço público federal no Centro de Educação da UFSM - Período: 30/05/2005 a 30/05/2005. Função: participante

- Registro GAP/CE 018395 - VI Seminário de Práticas de Ensino: Ensino Básico e Superior e I Seminário Integrado da Graduação e da Pós-Graduação do Centro Educação - Período: 13/12/2005 a 29/12/2006. Função: co-orientador.

\section{Projeto de pesquisa em 2005}

- Registro GAP/CE 017327 - Ciclos de vida profissional de professores do ensino superior: estudo sobre trajetórias docentes - Período: 01/03/2005 a 13/12/2007. Função: participante.

No ano de 2005 exerci a coordenação substituta do Curso de Pedagogia diurno e, no ano de 2007, exerci a função de coordenadora do curso de Pedagogia noturno, permanecendo até 2009 , sendo no ano subsequente, 2010 , coordenadora substituta. 
Figura 7 -

Encargos didáticos no primeiro semestre de 2006: 930 horas aula.

Encargo didático

\begin{tabular}{|c|c|c|c|c|}
\hline & $=$ Turma & \& Disciplina & \& Curso & ₹ Encargo didático (h) \\
\hline - & 11 & MEN415 - DIDATICA II & $\begin{array}{l}\text { Pedagogia - Magistério - Educaçăo } \\
\text { Pré-scscolar-621 }\end{array}$ & 105 \\
\hline - & 12 & MEN415 - DIDATICA II & $\begin{array}{l}\text { Pedagogia - Magistério Séries } \\
\text { Iniciais - } 622\end{array}$ & 105 \\
\hline - & 13 & $\begin{array}{l}\text { MEN425 - PRATICA DE ENS.NA } \\
\text { ESCOLA DE \| GRAU }\end{array}$ & $\begin{array}{l}\text { Pedagogia - Magistério - Educação } \\
\text { Pré-Escolar - } 621\end{array}$ & 90 \\
\hline - & 14 & $\begin{array}{l}\text { MEN425 - PRATICA DE ENS.NA } \\
\text { ESCOLA DE II GRAU }\end{array}$ & $\begin{array}{l}\text { Pedagogia - Magistério - Educação } \\
\text { Pré-Escolar - } 621\end{array}$ & 90 \\
\hline - & 12 & $\begin{array}{l}\text { MEN425 - PRATICA DE ENS.NA } \\
\text { ESCOLA DE ॥ GRAU }\end{array}$ & $\begin{array}{l}\text { Pedagogia - Magistério - Educação } \\
\text { Pré-Escolar - } 621 \text { 作 }\end{array}$ & 90 \\
\hline - & 11 & $\begin{array}{l}\text { MEN425 - PRATICA DE ENS.NA } \\
\text { ESCOLA DE } \| \text { GRAU }\end{array}$ & $\begin{array}{l}\text { Pedagogia - Magistério - Educação } \\
\text { Pré-Escolar - } 621\end{array}$ & 90 \\
\hline - & 14 & $\begin{array}{l}\text { MEN425 - PRATICA DE ENS.NA } \\
\text { ESCOLA DE II GRAU }\end{array}$ & $\begin{array}{l}\text { Pedagogia - Magistério Séries } \\
\text { Iniciais - } 622\end{array}$ & 0 \\
\hline - & 01 & $\begin{array}{l}\text { MEN425 - PRATICA DE ENS.NA } \\
\text { ESCOLA DE II GRAU }\end{array}$ & $\begin{array}{l}\text { Pedagogia - Magistério Séries } \\
\text { Iniciais - } 622\end{array}$ & 90 \\
\hline - & 12 & $\begin{array}{l}\text { MEN425 - PRATICA DE ENS.NA } \\
\text { ESCOLA DE \| GRAU }\end{array}$ & $\begin{array}{l}\text { Pedagogia - Magistério Séries } \\
\text { Iniciais - } 622\end{array}$ & 90 \\
\hline - & 13 & $\begin{array}{l}\text { MEN425 - PRATICA DE ENS.NA } \\
\text { ESCOLA DE \| GRAU }\end{array}$ & $\begin{array}{l}\text { Pedagogia - Magistério Séries } \\
\text { Iniciais - } 622\end{array}$ & 90 \\
\hline - & 11 & $\begin{array}{l}\text { MEN425 - PRATICA DE ENS.NA } \\
\text { ESCOLA DE II GRAU }\end{array}$ & $\begin{array}{l}\text { Pedagogia - Magistério Séries } \\
\text { Iniciais - } 622\end{array}$ & 90 \\
\hline \multicolumn{4}{|c|}{ Encargo didático total: } & 930 \\
\hline \multicolumn{5}{|c|}{ Aviso } \\
\hline
\end{tabular}

Fonte: Portal do professor/UFSM.

Figura 8 -

Encargos didáticos no segundo semestre de 2006: 180 horas aula.

Encargo didático

\begin{tabular}{|c|c|c|c|c|}
\hline & - Turma & - Disciplina & $\rightarrow$ Curso & - Encargo didático (h) \\
\hline (-) & 13 & $\begin{array}{l}\text { MEN425 - PRATICA DE ENS.NA } \\
\text { ESCOLA DE II GRAU }\end{array}$ & $\begin{array}{l}\text { Pedagogia - Magistério - Educação } \\
\text { Pré-Escolar - } 621\end{array}$ & 90 \\
\hline - & 13 & $\begin{array}{l}\text { MEN425 - PRATICA DE ENS.NA } \\
\text { ESCOLA DE II GRAU }\end{array}$ & $\begin{array}{l}\text { Pedagogia - Magistério Séries } \\
\text { Iniciais - } 622\end{array}$ & 90 \\
\hline
\end{tabular}

\section{Aviso}

Turmas de cursos EaD ou sem alunos, não contabilizam encargo didático.

BImprimir

Portal do professor - Versão 2.2.26

Fonte: Portal do professor/UFSM.

\section{Projetos de extensão em 2006}

a) Registro GAP/CE 018240 - Curso de Formação dos Membros do Magistério Público Estadual da 32a Coordenadoria Regional de Educação - Período: 10/03/2006 a 31/01/2007. Função: participante.

b) Registro GAP/CE 018482 - "Oficinas de Aquisição de Habilidades Básicas em Pesquisa I" - Período: 10/03/2006 a 31/01/2007- Função: Coordenação.

c) Registro GAP/CE 018486 - Laboratórios de metodologia de ensino do Centro de Educação - Período: 01/02/2006 a 28/12/2006. Função: coordenação. 
d) Registro GAP/CE 018487 - Oficinas de didática I - Período 01/02/2006 a 04/12/2006. Função: coordenação.

e) Registro GAP/CE 018488 - Apreendendo pedagogia I - Período 01/02/2006 a 22/12/2006. Função: coordenação.

f) Registro GAP/CE 018489 - Oficinas de aquisição de habilidades básicas em pesquisa I - Período 01/02/2006 a 20/12/2007. Função: coordenação.

g) Registro GAP/CE 018490 - Caleidoscópio cultural - Período 01/02/2006 a 10/12/2006. Função: coordenação.

h) Registro GAP/CE 019391 - Curso de Formação Continuada na E.E.E.B. Prof. Willy Roos (Agudo) - Ação Prodepd - Período 03/06/2006 a 30/09/2006. Função: participante.

i) Registro GAP/CE 016429 - Rodepd - Programa de Desenvolvimento Profissional Docente - Período 01/03/2007 a 31/12/2006. Função: participante.

\section{Projeto de ensino em 2006}

- Registro GAP/CE 018725 - Curso de Licenciatura em Pedagogia a Distância Período 12/04/2006 a 31/12/2010. Função: co-orientador.

- Registro GAP/CE 019582 - Curso de Licenciatura a Distância de Educação Especial - graduação - oferta $2^{\circ}$ ano - Período 02/10/2006 a 31/12/2007. Função: participação

- Registro GAP/CE 019765 - Práticas Educativas no Contexto da Formação de Professores da Educação Básica - qualificando as licenciaturas da UFSM - Período 01/12/2006 a 01/06/2007. Função: participante.

\section{Projeto de pesquisa em 2006}

a) Registro GAP/CE 018846 - A iniciação científica como processo de formação integral do jovem pesquisador - Período 01/06/2006 a 31/12/2013. Função: coordenadora.

Em 2006 aprovei este projeto de pesquisa no CNPq, o qual foi desenvolvido em parceria com a UFSC. Esse projeto foi sobre a orientação da iniciação científica. Foi um projeto muito grande. Resultou inclusive em uma tese de doutorado. Essa pesquisa durou até 2010.

Descrição: trabalhamos com o seguinte problema de pesquisa: quais são os valores que os alunos de iniciação científica apreendem no processo de orientação com seus orientadores e que tendências apontam tais valores? Se os orientadores exercem influências nessas aprendizagens desses acadêmicos, como exercem e quais são elas? Para isso, desenvolveremos uma pesquisa de campo cujo objetivo é pesquisar quais os valores que prevalecem na nova geração de futuros cientistas, qual o papel dos orientadores na aquisição desses valores e quais são os mecanismos envolvidos na transmissão desses valores. Para cumprir tal objetivo, faremos entrevistas com todos os estudantes de iniciação científica com no mínimo sete meses de IC do ano 2005-2006 em nossas instituições, UFSM e UFSC, e seus respectivos orientadores. A coleta das informações aconteceu em duas etapas, inicialmente por meio de questionários semiestruturados a ser respondido por alunos e professores para o levantamento dos principais valores humanos presentes na IC e depois, a partir de um roteiro pré-elaborado à luz dos dados obtidos, serão realizadas entrevistas aprofundando os temas identificados nos questionários. Ao final, compararemos os valores dos orientadores e dos orientandos, 
verificaremos o grau de influência que os orientadores exercem e teremos um panorama geral dos valores hoje em voga na atividade de iniciação cientifica. Com isso, poderemos propor atividades e metodologias adequadas para auxiliar na formação integral dos jovens para a atividade de pesquisa. Situação: concluída; Natureza: pesquisa. Alunos envolvidos: Graduação: (2) / Especialização: (1) / Mestrado acadêmico: (1) / Mestrado profissional: (0) / Doutorado: (1). Integrantes: Estela Maris Giordani - coordenador / Cecília Machado Henriques - Integrante / Adriane Maria Moro Mendes - Integrante / Daniela Aimi Integrante / Fabiana Binato da Rocha Brum - Integrante / Paola Dias Lippert - Integrante / MArcelo Artur Rauber - Integrante / Rebeca Binato da Rocha Brum - Integrante / Elen Cristina Bortoluzzi - Integrante / Evellyn Ledur da Silva - Integrante / Lisliane dos Santos Cardozo - Integrante / Daniela da Silva Aimi - Integrante. Financiador(es): Conselho Nacional de Desenvolvimento Científico e Tecnológico - Auxílio financeiro / Conselho Nacional de Desenvolvimento Científico e Tecnológico - Bolsa / Fundação de Amparo à Pesquisa do Estado do Rio Grande do Sul - Bolsa / Educação (UFSM) - Bolsa. Número de produções C, T \& A: 14 / Número de orientações: 10.

Figura 9 -

Encargos didáticos no primeiro semestre de 2007: 75 horas aula.

Encargo didático

\begin{tabular}{|c|c|c|c|c|}
\hline & - Turma & $\widehat{~ D i s c i p l i n a ~}$ & - Curso & - Encargo didático (h) \\
\hline - & 11 & $\begin{array}{l}\text { MEN1160 - CURRÍCULO : TEORIA E } \\
\text { HISTÓRIA }\end{array}$ & $\begin{array}{l}\text { Pedagogia - Licenciatura Plena } \\
\text { Diurno - } 628\end{array}$ & 30 \\
\hline - & 50 & MEN1083 - DIDÁTICA & $\begin{array}{l}\text { Educação Especial - } \\
\text { Licenciatura/Distância - } 634\end{array}$ & 0 \\
\hline - & 10 & $\begin{array}{l}\text { MEN823 - METODOLOGIA DO } \\
\text { ENSINO }\end{array}$ & $\begin{array}{l}\text { PG Distúrbios da Comunicação } \\
\text { Humana - Mestrado - } 997\end{array}$ & 45 \\
\hline
\end{tabular}

Figura 10 -

Encargos didáticos no segundo semestre de 2007: 300 horas aula.

Encargo didático

\begin{tabular}{|c|c|c|c|c|}
\hline & $\Leftrightarrow$ Turma & — Disciplina & $\neq$ Curso & F Encargo didático (h) \\
\hline 0 & 01 & $\begin{array}{l}\text { MEN1160 - CURRÍ́CULO : TEORIAE } \\
\text { HISTÓRIA }\end{array}$ & $\begin{array}{l}\text { Pedagogia - Licenciatura Plena } \\
\text { Noturno - } 627\end{array}$ & 30 \\
\hline 0 & 10 & MEN1159 - DIDÁTICA & $\begin{array}{l}\text { Pedagogia - Licenciatura Plena } \\
\text { Diurno - } 628\end{array}$ & 60 \\
\hline 0 & 01 & $\begin{array}{l}\text { CCP1021 - PED V - PRÁTICA } \\
\text { EDUCATIVA I }\end{array}$ & $\begin{array}{l}\text { Pedagogia - Licenciatura Plena } \\
\text { Noturno - } 627\end{array}$ & 30 \\
\hline 0 & 10 & $\begin{array}{l}\text { MEN425 - PRATICA DE ENS.NA } \\
\text { ESCOLA DE II GRAU }\end{array}$ & $\begin{array}{l}\text { Pedagogia - Magistério - Educação } \\
\text { Pré-Escolar - } 621\end{array}$ & 90 \\
\hline 0 & 10 & $\begin{array}{l}\text { MEN425 - PRATICA DE ENS.NA } \\
\text { ESCOLA DE ॥ GRAU }\end{array}$ & $\begin{array}{l}\text { Pedagogia - Magistério Séries } \\
\text { Iniciais - } 622\end{array}$ & 90 \\
\hline
\end{tabular}

\section{Projeto de extensão em 2007}

a) Registro GAP/CE 020197 - Oficina de aquisição de habilidades básicas em pesquisa - Período 26/04/2007 a 30/12/2007. Função: coordenador.

b) Registro GAP/CE 020198 - Oficinas de Didática I - Período 27/04/2007 a 30/12/2007. Função: coordenador. 


\section{Projeto de pesquisa em 2007}

a) Registro GAP/CE 020117 - Aprendizagem docente e processos formativos: novas perspectivas para a educação básica e superior - Período 01/01/2007 a 30/12/2010. Função: participante.

b) Registro GAP/CE 020229 - A iniciação científica no Prolicen/2006: os valores na formação docente - Período 25/04/2007 a 31/12/2007. Função: coordenador.

\section{Projeto de ensino em 2007}

- Registro GAP/CE 020257 - Jogos eletrônicos: a ludicidade como suporte para o ensino de história - Período 07/05/2007 a 31/01/2008. Função: colaborador.

No ano de 2007, organizamos um livro sobre os estágios curriculares supervisionados, no qual também publiquei um capítulo de livro: GIORDANI, E. M; MENDES, A. M. M. A subjetividade no processo pedagógico das orientações no ensino superior. In: FREITAS, D. S; GIORDANI. E. M; CORRÊA, G. C (org.). Ações educativas e estágios curriculares supervisionados. Santa Maria: UFSM, 2007, p. 87-107.

Figura 11 -

Encargos didáticos no primeiro semestre de 2008: 195 horas aula.

\begin{tabular}{|c|c|c|c|c|}
\hline & F Turma & - Disciplina & - Curso & - Encargo didático (h) \\
\hline- & 12 & MEN1159 - DIDÁTICA & $\begin{array}{l}\text { Pedagogia - Licenciatura Plena Diurno - } \\
628\end{array}$ & 60 \\
\hline - & 10 & $\begin{array}{l}\text { PPGADM800 - DIDÁTICA DE ENSINO } \\
\text { SUPERIOR }\end{array}$ & $\begin{array}{l}\text { PG - Administração - Mestrado } \\
\text { Acadêmico - } 889\end{array}$ & 60 \\
\hline - & 10 & $\begin{array}{l}\text { MEN854 - DOCÊNCIA NO ENSINO } \\
\text { SUPERIOR }\end{array}$ & $\begin{array}{l}\text { PG Distúrbios da Comunicação Humana } \\
\text { - Mestrado - } 997\end{array}$ & 45 \\
\hline - & 36 & $\begin{array}{l}\text { FUE1049 - INTRODUÇÃO À PEDAGOGIA } \\
\text { - EAD }\end{array}$ & $\begin{array}{l}\text { Pedagogia-Licenciatura/Distância } \\
\text { /Sobradinho/RS - 636.EAD.06 }\end{array}$ & 0 \\
\hline - & 37 & $\begin{array}{l}\text { FUE1049 - INTRODUÇĂO À PEDAGOGIA } \\
\text { - EAD }\end{array}$ & $\begin{array}{l}\text { Pedagogia-Licenciatura/Distância } \\
\text { /apejara/RS - 636.EAD. } 07\end{array}$ & 0 \\
\hline - & 38 & $\begin{array}{l}\text { FUE1049 - INTRODUÇÃ̃ À PEDAGOGIA } \\
\text { - EAD }\end{array}$ & $\begin{array}{l}\text { Pedagogia-Licenciatura/Distância/Três } \\
\text { de Maio/RS - 636.EAD.08 }\end{array}$ & 0 \\
\hline - & 39 & $\begin{array}{l}\text { FUE1049 - INTRODUÇÃO À PEDAGOGIA } \\
\text { - EAD }\end{array}$ & $\begin{array}{l}\text { Pedagogia-Licenciatura/Distância/Três } \\
\text { Passos/RS - 636.EAD.09 }\end{array}$ & 0 \\
\hline - & 31 & $\begin{array}{l}\text { FUE1049 - INTRODUÇÃO À PEDAGOGIA } \\
\text { - EAD }\end{array}$ & $\begin{array}{l}\text { Pedagogia/Distância/Cruz Alta/RS - } \\
\text { 636.EAD.01 }\end{array}$ & 0 \\
\hline - & 32 & $\begin{array}{l}\text { FUE1049 - INTRODUÇÃO À PEDAGOGIA } \\
\text { - EAD }\end{array}$ & $\begin{array}{l}\text { Pedagogia/Distância/Faxinal do } \\
\text { Soturno/RS - } 636 . E A D .02\end{array}$ & 0 \\
\hline - & 33 & $\begin{array}{l}\text { FUE1049 - INTRODUÇÃO À PEDAGOGIA } \\
\text { - EAD }\end{array}$ & $\begin{array}{l}\text { Pedagogia/Distância/Restinga Sêca/RS - } \\
\text { 636.EAD.03 }\end{array}$ & 0 \\
\hline - & 34 & $\begin{array}{l}\text { FUE1049 - INTRODUÇÃO À PEDAGOGIA } \\
\text { - EAD }\end{array}$ & $\begin{array}{l}\text { Pedagogia/Distância/Santana do } \\
\text { Livramento/RS - 636.EAD.04 }\end{array}$ & 0 \\
\hline - & 35 & $\begin{array}{l}\text { FUE1049 - INTRODUÇÃO À PEDAGOGIA } \\
\text { - EAD }\end{array}$ & $\begin{array}{l}\text { Pedagogia/Distância/São Lourenço do } \\
\text { SulRS - } 636 \text {.EAD.05 }\end{array}$ & 0 \\
\hline - & 2 & $\begin{array}{l}\text { CCP1020 - PED IV - EDUCAÇÃO EM } \\
\text { DIFERENTES MODALIDADES }\end{array}$ & $\begin{array}{l}\text { Pedagogia - Licenciatura Plena Noturno - } \\
627\end{array}$ & 30 \\
\hline
\end{tabular}

Fonte: Portal do professor/UFSM. 
Figura 12 -

Encargos didáticos no segundo semestre de 2008: 240 horas aula.

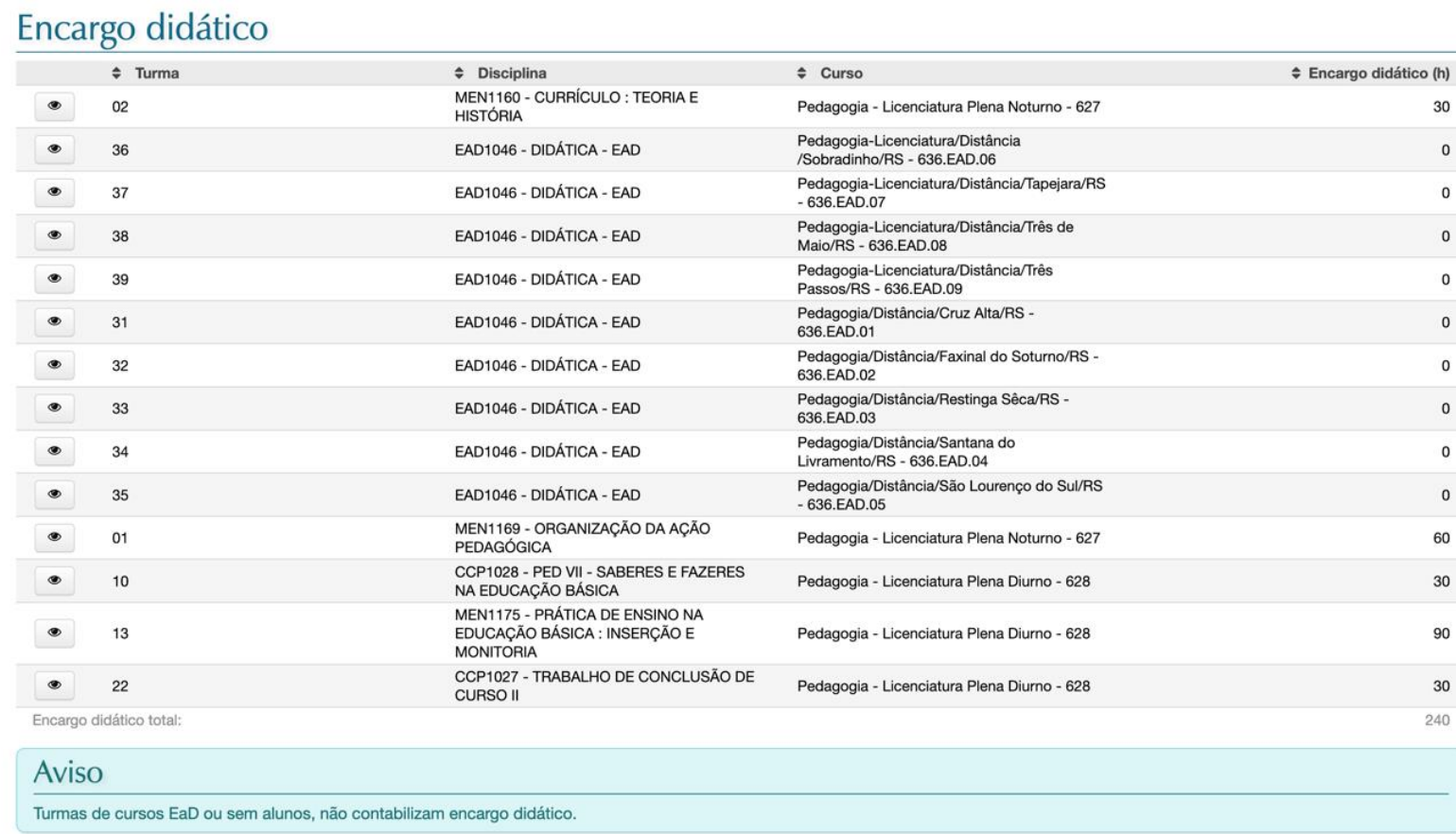

Fonte: Portal do professor/UFSM.

\section{Projeto de pesquisa em 2008}

a) Registro GAP/CE 021991 - Ciclos de vida profissional de professores do ensino superior: um estudo comparativo sobre trajetórias docentes - Período 01/03/2008 a 30/04/2010. Função: participante.

b) Registro GAP/CE 022533- Materiais didáticos no ensino fundamental e médio Período 16/04/2008 a 31/12/2013. Função: coordenador. Situação: concluído; Natureza: pesquisa. Alunos envolvidos: Graduação: (4) / Mestrado acadêmico: (3). Integrantes: Estela Maris Giordani - coordenador / Evellyn Ledur da Silva - Integrante / Caroline Jorge Cezar - Integrante / Dinara Soraia Ebbing - Integrante / Jander Fernandes Martins Integrante / Sandra Fabiane Kleszta de Jezus - Integrante / Angelita Vargas Brazil Integrante / leda Fatima da Silva Brandeburski - Integrante / Renata Carvalho Santos Silva - Integrante / Maria Alice Castilho Schuch - Integrante.

Até aqui brevemente apresentei em forma de 'sobrevoo' para poder situar e fundamentar as bases da minha atuação profissional de modo a poder dar a compreensão na continuidade que segue dos meus últimos dez anos, objeto deste memorial.

\section{A segunda etapa: os dez últimos anos na UFSM (2009-2019)}

Neste capítulo opto em apresentar meu memorial seguindo a lógica do tempo, pois facilita. Com isso intento relacionar e não segmentar as atividades de ensino pesquisa e extensão. Isso porque, também devido a minha trajetória, meus estudos sobre a interdisciplinaridade e compreender o ser humano em seus aspectos integrais. Portanto, na sequência, as atividades de ensino, pesquisa e extensão estão entrelaçadas sendo 
que utilizarei a linha temporal, embora não de forma linear, visto que, alguns projetos se iniciam em algum momento, mas não são concluídos dentro daquele mesmo período do ano, geralmente levam mais tempo.

Embora nem sempre tudo o que fiz teve o registro ou o reconhecimento oficial do sistema, trata-se de uma ação com a preocupação em compreender cada vez mais, minhas inquietações: 1) a mim mesmo, consciente e inconsciente; 2) o ser humano e ao mesmo tempo cada individualidade que contato como aprendiz na relação ensinoaprendizagem; 3) minhas inquietações com o processo do aprender e do ensinar.

Considero essa a segunda etapa por dois motivos. Primeiro, pois no ano de 2009 solicitei mudança de regime de trabalho da dedicação exclusiva e iníciei a minha jornada junto a Faculdade Antônio Meneghetti - portaria n. 56.245, de 9 de novembro de 2009, altera o art. de dedicação exclusiva para 40 horas a partir de 5 de novembro de 2009 . Então, não apenas porque essa etapa remete a dez anos atrás, mas principalmente porque estes dez anos foram sem o regime de trabalho de dedica exclusiva. Portanto, em segundo lugar, estes meus últimos dez anos foram marcados pelo trabalho concomitante na UFSM e na Faculdade Antonio Meneghetti - AMF. E, então por poder dedicar-me a estudar mais, pesquisar mais a ciência e a pedagogia Ontopsicológica. Isso porque, não existe nada pronto, a estrada da ciência e da pedagogia foram iniciadas com o Patrono desta ciência, desta pedagogia, contudo, tudo ainda está por ser desenvolvido. Analogamente poderia dizer que agora temos uma célula tronco de uma ciência e que a partir do trabalho de tantos outros pesquisadores das mais variadas áreas, no meu caso, da pedagogia, temos o legado de dar corpo e desenvolver o trabalho iniciado pelo Acc. Antonio Meneghetti. Esta foi a estrada que optei por trilhar e, nestes últimos anos, cada vez dediquei-me mais.

Minha preocupação nestes últimos dez anos foi em formalizar práticas pedagógicas partindo dos princípios da pedagogia Ontopsicológica. Ou seja, como colocar em prática educativas em diversos âmbitos: na família, nas escolas e especialmente, na formação de professores, especialmente pedagogos? Diria que este foi o mote que me moveu ao longo destes últimos dez anos.

Embora tendo a impossibilidade de trabalhar na pós-graduação na UFSM, busquei me inserir em outros programas e espaços de pós-graduação, ministrei várias disciplinas e também tive a participação em várias pesquisas, embora nem sempre registrando na UFSM estes percursos.

Também, sendo sócia-proprietária da Identità - Formação e Pesquisa Interdisciplinar, desenvolvi várias atividades de assessoria e formação profissional em empresas, as atividades foram intensas. Aventurei-me em várias estradas até o ano de 2017, ano em que eu iniciei um novo caminho na coordenação do curso de Pedagogia da Faculdade Antonio Meneghetti. O projeto do curso de pedagogia da AMF, seguindo o background da pedagogia e todos os preceitos legais, foi construído a partir dos princípios da ciência Ontopsicológica e da Pedagogia Ontopsicológica.

$\mathrm{Na}$ UFSM o primeiro semestre de 2009 tive 510 horas de encargos didáticos. Praticamente as disciplinas ministradas eram na Especialização e no Mestrado em Geomática - Metodologia do Ensino e no curso de licenciatura em Pedagogia os estágios dos anos iniciais do ensino fundamental. 
Figura 13 -

Encargos didáticos no primeiro semestre de 2009: 510 horas aula.

Encargo didático

\begin{tabular}{|c|c|c|c|c|}
\hline & * Turma & A Disciplina & * Curso & * Encargo didático (h) \\
\hline - & 03 & MEN1159 - DIDÁTICA & Pedagogia - Licenciatura Plena Noturno - 627 & 60 \\
\hline - & 11 & $\begin{array}{l}\text { MEN1184 - ESTÁGII SUPERVIIIONADO NOS ANOS INICIAIS } \\
\text { DO ENSINO FUNDAMENTAL }\end{array}$ & Pedagogia - Licenciatura Plena Diurno - 628 & 150 \\
\hline - & 12 & $\begin{array}{l}\text { MEN1184 - ESTÁGIO SUPERVISIONADO NOS ANOS INICIAIS } \\
\text { DO ENSINO FUNDAMENTAL }\end{array}$ & Pedagogia - Licenciatura Plena Diurno - 628 & 150 \\
\hline - & 36 & FUE1049 - INTRODUÇĀO Á PEDAGOGIA - EAD & Pedagogia-Licenciatura/Distância/Sobradinho/RS - 636.EAD.06 & 0 \\
\hline - & 37 & FUE1049 - INTRODUĢ̄̄O A PEDAGOGIA - EAD & Pedagogia-Licenciatura/Distância/apejara/RS - 636.EAD.07 & 0 \\
\hline - & 38 & FUE1049 - INTRODUÇĀO À PEDAGOGIA - EAD & Pedagogia-Licenciatura/Distância/ries de Maio/RS - 636.EAD.08 & 0 \\
\hline - & 39 & FUE1049 - INTRODUÇĀO À PEDAGOGIA - EAD & Pedagogia-Licenciaturadidstância/rés Passoss/RS - 636.EAD.09 & 0 \\
\hline - & 31 & FUE1049 - INTRODUÇÃO À PEDAGOGIA - EAD & Pedagogia/istäncia/Cruz Alta/RS - 636.EAD.01 & 0 \\
\hline - & 32 & FUE1049 - INTRODUÇ̨̃ A A PEDAGOGIA - EAD & Pedagogiadistância/Faxinal do Soturno/RS - 636.EAD.02 & 0 \\
\hline - & 40 & FUE1049 - INTRODUÇĀOA À PEDAGOGIA - EAD & Pedagogia/istatanciaP anambi/RS - 636.EAD.10 & 0 \\
\hline - & 33 & FUE1049 - INTRODUÇĀO A A PEDAGOGIA - EAD & Pedagogiadistância/Restinga Sêca/RS - 636.EAD.03 & 0 \\
\hline - & 34 & FUE1049 - INTRODUÇĀ́O A PEDAGOGIA - EAD & Pedagogiadistância/Santana do Livramento/RS - 636.EAD.04 & 0 \\
\hline - & 35 & FUE1049 - INTRODUÇÃO À PEDAGOGIA - EAD & Pedagogia/Distância/Săo Lourenço do Su/RS - 636.EAD.05 & 0 \\
\hline - & 10 & MENB53 - METODOLOGIA DO ENSINO & PG em Geomática-Especializaçâo - 897 & 60 \\
\hline - & 888 & MENBS3 - METODOLOGIA DO ENSINO & PG Mestrado em Geomática - 888 & 60 \\
\hline - & 03 & $\begin{array}{l}\text { CCP1020 - PED N - EDUCACĀOA EM DIFERENTES } \\
\text { MODALDADES }\end{array}$ & Pedagogia - Licenciatura Plena Noturno - 627 & 30 \\
\hline
\end{tabular}

Fonte: Portal do professor/UFSM.

No segundo semestre de 2009, ministrei 286 horas aulas, conforme consta no Portal do Professor da UFSM. Neste semestre iniciei a ministrar disciplina no Mestrado em Distúrbios da Comunicação Humana.

Figura 14 -

Encargos didáticos no segundo semestre de 2009: 286 horas aula. Encargo didático

\begin{tabular}{|c|c|c|c|c|}
\hline & i Turma & ; Disciplina & i Curso & † Encargo didático ( (h) \\
\hline - & 10 & MEN1137-DDATICA & Misica - Ucenciatura Plena - 734 & 60 \\
\hline - & 10 & MENBS4- DOCENCAA NOENSNO SUPERIOR & 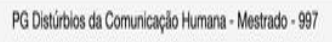 & 45 \\
\hline - & 13 & $\begin{array}{l}\text { MEN1184 E ESTAGGO SUPERYSIONADO NOS ANOS INCAIS } \\
\text { DO ENSNONO FUNDAMENTAL }\end{array}$ & 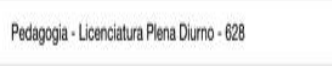 & 150 \\
\hline - & 10 & $\begin{array}{l}\text { CCP1O28 - PED VII- SABERESE FARERES NA EDUCACAO } \\
\text { BASICA }\end{array}$ & Pedagegala - Liconciatura Plena Diumo - 628 & 30 \\
\hline - & 38 & CCP1026- TAABALHO DE CONCLLSAOO OE CURSOI & Pedaggga - L Leenciatura Plena Durno - 628 & 1 \\
\hline \multicolumn{4}{|c|}{ Encurgo oldiailco total: } & 288 \\
\hline \multicolumn{5}{|c|}{ Aviso } \\
\hline
\end{tabular}

Fonte: Portal do professor/UFSM.

Um outro marco muito importante neste período foi ter participado do Conselho Assessor para Assuntos Internacionais junto a Secretaria de Assuntos Internacionais SAI. Ocorrência: 08.01.02.07.00 - Conselhos. Data de Início: 05/06/2009 - Data de Término: 31/12/2018. 
Por que foi importante? Porque me confrontei com questões práticas e pude ampliar minhas reflexões em questões profundas tais como: como selecionar o melhor candidato para fazer intercambio em outros países que disponibilizavam a existência de vaga nas universidades? Como preparar melhor os jovens para o processo de internacionalização? Como auxiliar para que o período de vivência em outro país, outra universidade se tornasse rico e, também pudesse ser transmitido a outros aprendizes? Por que alguns dos processos de intercâmbios dão problemas? Quais são os elementos que podem contribuir para facilitar o processo de interação intercultural da melhor forma?

Percebia que havia muito despreparo do ponto de vista da maturidade pessoal dos candidatos. Muitas vezes se tratava de pessoas que tinham boas trajetórias acadêmicas, mas que não possuíam estrutura emocional para viver sozinhas e enfrentar os diferentes e pequenos desafios do cotidiano de um contexto longe da família de amigos e pessoas as quais podem the auxiliar a resolver os seus problemas.

Ou seja, as respostas das perguntas remetem a questões estruturais do como pensamos a formação das nossas gerações. Consideramos que a formação deve ser em relação a aprendizagens relativas essencialmente aos aspectos de conhecimentos, e nem sempre estes implicando o desenvolvimento das funções cognitivas, que de fato é outra questão, sem dúvida conectada com tudo, mas não significa a mesma coisa. Analogamente, é como se estivéssemos falando dos ossos da mão, uma coisa são os ossos do dedo polegar, e outra coisa são os ossos do dedo indicador. Ambos possuem funções e especificidades, contudo no contexto do apanhar algum objeto são coordenados para a mesma função. E, as demais dimensões como as emoções, a capacidade de lidar com problemas simples do dia a dia da vida, capacidade de trabalhar em equipe etc. será que não seriam importantes tanto quanto saber o idioma e ter boas notas nos componentes curriculares cursados?

\section{Participação concurso público em 2009}

a) Banca examinadora para seleção pública para contratação de professor substituto, 2009. Universidade Federal de Santa Maria. Banca para professor substituto na área de Didática e Prática de Ensino, 2009

b) Concurso público professor assistente Didática e Prática de Ensino em Língua Portuguesa, 2009. Universidade Federal de Santa Maria.

c) Professor adjunto na área de Biologia para a Educação Básica, 2009. Universidade Federal de Santa Maria.

Minhas aprendizagens da participação dos concursos públicos. Percebia que os concursos por mais objetivos que eram pensados, a banca, subjetivamente definia 0 candidato que tinha preferência. É uma coisa boa? É ruim? Não tenho uma posição fechada a respeito. Mas sempre dependia da banca. Se a banca fosse boa, a seleção também era boa, se a banca refletia algo que não fosse bom, também a seleção, em seu processo ocorria de forma truncada - as vezes faltava documento por parte da banca para assinar, enfim, sempre aconteciam fatores aparentemente isolados de percalços que, sempre poderiam remeter a algo de não conforme, de distônico aquele processo. Sem dúvida alguma, aparentemente tudo normal. Mas o inconsciente existe, e, segundo Freud é a maior parte da atividade psíquica do ser humano, ele corresponde até de 80 a $90 \%$. E, então, é preciso saber compreender a sua linguagem, saber considerar esta variável e 
incorporar esta variável no contexto humano. Pois, segundo Meneghetti, tudo o que é humano, para quem trabalha com o ser humano deve interessar. O inconsciente é parte constituinte da vida humana no aqui e agora. E, não o relevar é simplesmente descartar de 80 a $90 \%$ do que é o humano.

Portanto, se fala de interculturalidade e de desigualdades, etc., fala-se de aceitar as diferenças. Temos dentro de nós mesmos a diferença do aspecto consciente e do aspecto inconsciente. São duas vidas, duas dimensões que coexistem no interior humano de cada um de nós. Aceitar e integrar esta desigualdade é voltar a habitar a própria casa, a casa que é nossa, integrando as partes que são nossas.

Outra aprendizagem muito interessante das bancas de seleção e concursos públicos, derivada da experiência vivida, comecei a refletir sobre como deveria ser este processo. Que dimensões são consideradas, por que são consideradas estas e não outras? Não haveria outras dimensões tão importantes para o processo de seleção? Por que estas dimensões são tão valoradas? Será que as dimensões mais valoradas são aquelas que de fato as que mais impactam na formação da profissionalização dos nossos jovens? Que dimensões avaliativas fariam a diferença?

De fato, se na carreira do professor universitário ele se insere dentro de um departamento, dentro de um currículo de formação, o qual requer um perfil profissional, não teriam que as áreas problematizar a formação das futuras gerações? Dito de outro modo, para além dos conhecimentos considerados, da boa didática será que componentes como o saber se colocar no lugar do outro, a responsabilidade, a capacidade de trabalhar em projetos coletivos e para um bem comum, não teriam igualmente importância em um projeto de formação profissional, seja ele um médico, advogado, engenheiro ou professor?

$\mathrm{E}$, portanto, não teríamos que, nós, intelectuais, protagonistas dos nossos processos - porque quem pensou, desenhou, formalizou e colocou em funcionamento os processos fomos nós - estamos no caminho adequado de formar as novas gerações na direção que nos foi indicada no artigo $2^{\circ}$ da LDB significa que vale para toda e qualquer educação, formal, informal, institucional não institucionalizada etc. "Art. 20 A educação, dever da família e do Estado, inspirada nos princípios de liberdade e nos ideais de solidariedade humana, tem por finalidade o pleno desenvolvimento do educando, seu preparo para 0 exercício da cidadania e sua qualificação para o trabalho".

Então daí nasceu também o meu desejo de me debruçar sobre as dimensões da formação profissional do pedagogo - embora nem sempre tenha escrito ou pesquisado formalmente tudo o que penso e todas as minhas indagações. Mas, dentro de mim, a chama o interesse que me move é este. E, no ano de 2019, entrando no PPGAP Mestrado em Administração Pública, tive a oportunidade de ter uma orientanda que está se aventurando comigo a entrar nesta árdua discussão. Como se realizam os processos de seleção pública para professores da educação básica nos municípios do Rio Grande do Sul? Honestamente tenho mais perguntas do indicações de como solucionar tais questões e talvez a pesquisa me dê mais perguntas ainda. Contudo, o caminho da pesquisa, da construção do conhecimento sempre me mostrou que esta é estrada ... não importa quão árdua seja. É a pergunta a rainha que está no trono e, que à ela vem de joelhos as respostas. 


\section{Meu foco de temática de pesquisa}

A partir das oficinas que havia ministrado e das pesquisas que desenvolvi até então, continuei nesta etapa uma pesquisando sobre a formação de professores e comecei a me dedicar e elaborar e pesquisar a técnica da Leitura Inteligente. A técnica da leitura inteligente eu a denominei assim porque se tratava de um passo a passo, resultado de vários estudos que havia empreendido e que buscava auxiliar os aprendizes em relação à vários aspectos do processo: interesse e disciplina pelo estudo, organização e clareza das ideias no percurso do estudo. Mas, principalmente, enfrentar o grave problema da falta de compreensão e da apropriação e baixa capacidade de estabelecer o diálogo com os autores quando entra em contato com um corpo teórico mais denso. Grande parte dos estudantes, no ensino superior, possuem uma relação superficial com os estudos e com os textos, sabem ser "alunos" porém não aprenderam a se tornarem estudantes capazes de exercer com autonomia e capacidade crítica diante de princípios, proposições e teorias. Essa pesquisa me trouxe grandes aprendizados, não apenas teóricos, mas me auxiliou muito no desenvolvimento das aulas, orientação dos estágios e dos projetos de orientação de IC, TCCs e dissertação de mestrado. Ou seja, além de ser objeto de estudo, tornou-se instrumento de trabalho muito útil.

Neste período entre 2009 em diante também iniciei a trabalhar com o Mestrado em Políticas e Administração da Educação na Universidade Tres de Febrero na Argentina. Ministrei disciplinas, também tive várias alunas que foram minhas orientandas.

\section{Participação como docente e orientadora de dissertações no Programa Maestria en Politicas y Administración de la Educación em 2009}

Neste período também continuava com a docência em disciplinas no programa de mestrado e também orientações de dissertação de Mestrado em Maestria en Politicas $Y$ Administración de la Educación, na Universidad de Tres de Febrero, em Buenos Aires Argentina.

GIORDANI, E. M; FILIPPIS, I; LAMARRA, N. F. Participação em banca de Yolanda Pereira Morel. Formación de formadores en supervisión educacional, 2009. (Maestría en Políticas y Administración de la Educación) Universidad Nacional de Tres de Febrero.

\section{Orientações de mestrado em 2009}

Lilian Mary Martins Zieger. Condição humana de professores idosos aposentados e as políticas públicas para a qualidade de vida no envelhecimento. 2009. Dissertação, Maestría en Políticas y Administración de la Educación, Universidad Nacional de Tres de Febrero.

Yolanda Pereira Morel. Formación de Formadores en Supervisión Educacional. 2009. Dissertação, Maestría en Políticas y Administración de la Educación, Universidad Nacional de Tres de Febrero.

$\mathrm{O}$ aprendizado de participar de um mestrado internacional me deu amplitude de mente. Embora fazer pesquisa em essência seja a mesma em qualquer que seja o lugar, o modo varia muito. Analogamente é como se fossemos falar de fazer arroz para um gaúcho e um chinês. Arroz é arroz sempre, mas no final das contas, o arroz branco fino servido na mesa de um gaúcho é muito diverso do arroz branco servido na mesa de um chinês. Enfim, ciência é ciência, arroz é arroz, mas há um universo de variáveis que 
existem entre o arroz branco do gaúcho e o arroz branco do chinês. Assim também é o fazer a pesquisa entre diversas culturas, diferentes universidades. Não há o melhor, existe o diverso. Para navegar naquele contexto é preciso considerar a lógica do fazer pesquisa, do fazer ciência, os procedimentos diversos que existem e segui-los. Além disso, nosso sistema de pós-graduação é muito elaborado, estruturado - países como a Suíça não tem um sistema único de registro de produtividade docente como artigos, livros, etc. em plataforma lattes como nós temos aqui no Brasil. Enfim, as formas são muito diversas e os valores nossos são relativos em outros contextos. Esta foi a riqueza colhida, que constituiu a silenciosa mas potente formação que fui construindo, por não ter podido ser parte do programa de mestrado e doutorado no centro de educação. Pode ter sido um para alguns um limite, mas honestamente, se não fosse por isso, teria ficado pobre destas experiências tão profundas que me tornaram a pessoa que hoje eu sou.

Entender essa diversidade foi muito interessante, especialmente porque vivi a oportunidade de fazer pesquisa na Universidade Estatal de São Petersburgo, na Faculdade de Psicologia e, lá compreendi que embora trabalhavam com a metodologia estatística, esta estava à serviço da intuição e da visão qualitativa da pesquisa. Ou seja, o aspecto quantitativo nunca se sobrepôs ao aspecto qualitativo, este era considerado no contexto, na relação, mas nunca na determinação da causa explicativa.

Neste mesmo período iniciei a minha breve trajetória no Programa de Mestrado Acadêmico em Administração da UFSM, no qual ministrava também a disciplina de Técnicas de Ensino, e orientava a dissertação de Mestrado. Depois disso, encerrei a minha participação neste programa de mestrado, em 2009, com a defesa da dissertação de Mestrado da Soraia Schutel ${ }^{4}$. GIORDANI, E. M. Presidente banca de Soraia Schutel. Pesquisa-ação na vivência de sustentabilidade do projeto internacional da arte e cultura humanista Recanto Maestro, 2009. (Mestrado em Administração) Universidade Federal de Santa Maria.

Depois encontrei espaço no Mestrado em Distúrbios da Comunicação Humana e depois no Mestrado em Geomática, ministrando a disciplina de Métodos e Técnicas de Ensino. Embora sem orientações, também tentei me inserir no Mestrado em Educação. Contudo, todas as tentativas foram frustradas. Então, decidi investir minha inteligência em outros âmbitos.

As aprendizagens da passagem pelo mestrado em Geomática foi o mesmo que da vivência em programas de mestrado internacionais, ou seja, embora sendo no Brasil, na mesma universidade, a forma mentis da pesquisa era completamente diversa. Conviver com a diversidade foi romper paradigmas mentais fechados, quadrados, obtusos que eu possuía, mas que não tinha ideia que eu tivesse. A descoberta de saber coisas que eu não sei foi mesmo incrível, dolorida, as vezes incomoda, mas sempre no final me levavam para horizontes superiores de capacidade mental.

${ }^{4}$ SCHUTEL, Soraia. Ontopsicologia e formação de pessoas na gestão sustentável do Centro Internacional de Arte e Cultura Humanista Recanto Maestro/RS. 2010. 132 f. Dissertação (Mestrado em Administração) - Universidade Federal de Santa Maria, Santa Maria, 2010.

\begin{tabular}{l|l} 
v. 10 & N. especial
\end{tabular}

e67467, p. 1-60

2021 


\section{Orientação de iniciação científica}

Anderson Denardin Cardoso. Materiais didáticos no ensino fundamental e médio. 2009. Iniciação científica (Ciências Sociais) - Universidade Federal de Santa Maria. Inst. financiadora: Projetos e bolsas de iniciação à pesquisa.

Ariane Wollenhoupt da Luz Rodrigues. A iniciação científica como processo de formação integral do jovem pesquisador. 2009. Iniciação científica (licenciatura em Pedagogia) - Universidade Federal de Santa Maria. Inst. financiadora: Fundação de Amparo à Pesquisa do Estado do Rio Grande do Sul.

Destes projetos de pesquisa nasceram publicações em congressos e também em revistas e uma co-orientação de doutorado, a qual, participei de banca e que, para participar da banca, abri mão do documento que comprovava a co-orientação.

Figura 15 -

Encargos didáticos no primeiro semestre de 2010: 330 horas aula.

\begin{tabular}{|c|c|c|c|c|}
\hline & A Turma & ; Disciplna & A Curso & \& Encargo odidático (M) \\
\hline - & 13 & $\begin{array}{l}\text { MEN1184 - ESTAGGIO SUPERNSIONADO NOS ANOS INCIAIS } \\
\text { DO ENSINO FUNDAMENTAL. }\end{array}$ & Pedagogala - Licenciatura Plena Diuno - 628 & 150 \\
\hline - & 10 & MENBS5 - METOOOLOGIA DO ENSINO 'A' & PG em Geomática - Especalizaça - 897 & 60 \\
\hline - & 11 & MENBS5 - METOOOOLGAADO ENSINO 'A' & PG Mestracico om Goomálica- 888 & 60 \\
\hline - & 50 & CCP1026- TRABALHO DE CONCLUSAO DE CURSOI & Pedagogala - Licenciatura Plena Diumo- 628 & 30 \\
\hline - & 33 & CCP1027 - TAABALHO DE CONCLUSAO DE CURSO॥ & Pedagogal - Licenciatura Plena Duurno - 628 & 30 \\
\hline \multicolumn{4}{|c|}{ Encargo didatilco total: } & 330 \\
\hline \multicolumn{4}{|c|}{ Aviso } & \\
\hline
\end{tabular}

Fonte: Portal do professor/UFSM.

Figura 16 -

Encargos didáticos no segundo semestre de 2010: 225 horas aula.

Encargo didático

\begin{tabular}{|c|c|c|c|c|}
\hline & - Turma & ; Disciplina & - Curso & O Encargo didatitco ( $(\mathrm{m})$ \\
\hline - & 11 & EAD1335 - DDÁTICA DA SOCIOLOGIAI & 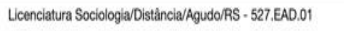 & 0 \\
\hline - & 12 & EAD1335 - DIDATCA DA SOCIOLOGIAI & 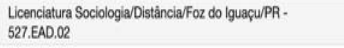 & 0 \\
\hline - & 13 & EAD1335-DDÁTICA DA SOCIOLOGIAI & 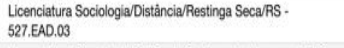 & 0 \\
\hline - & 14 & EAD1335 - ODDATCA DA SOCIOLOGIAI & 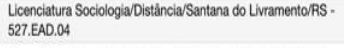 & 0 \\
\hline - & 15 & EAD1335 - DIDËTCA DA SOCIOLOGIAI & 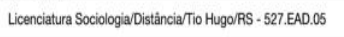 & 0 \\
\hline - & 10 & MENBS4 - DOCENCAA NO ENSINO SUPERROR & PG Distúribios da Comunicacáio Humana - Mestrado - 997 & 45 \\
\hline - & 12 & $\begin{array}{l}\text { MEN1184 - ESTAGGIOS SUPERNSIONADO NOS ANOS INCIIS } \\
\text { DO ENSNO FUNDAMENTL }\end{array}$ & Pedagoga - Licenclatura Plena Diumo - 628 & 150 \\
\hline - & 50 & CCP1027-TTABALHO DE CONCLUSÃO DE CURSO II & Pedaggogla - Lcenciatura Plena Dumo - 628 & 30 \\
\hline \multicolumn{4}{|c|}{ Encargo odidatico total: } & 225 \\
\hline \multicolumn{5}{|c|}{ Aviso } \\
\hline
\end{tabular}

Fonte: Portal do professor/UFSM. 


\section{Participação em seleção pública em 2010}

a) Banca examinadora para seleção pública - professor substituto área de Didática, Metodologia e Estágio Curricular Supervisionado de Língua Espanhola na Educação Básica, 2010. Universidade Federal de Santa Maria.

b) Banca examinadora para seleção pública - professor substituto área de Didática, Prática de Ensino da Língua Portuguesa, 2010. Universidade Federal de Santa Maria

No ano de 2010 participei de bancas examinadoras de seleção pública para professor substituto das áreas de Didática e Estágio Curricular da Língua Espanhola e Língua Portuguesa. Foi uma experiência interessante porque pensar a didática e os estágios na formação de professores das áreas do currículo e fazendo as interfaces com a pedagogia me enriqueceu muito. Existem muitos aspectos comuns, mas ao mesmo tempo coexistem a forma mentis de cada área específica. E os olhares dos colegas de banca nos diálogos estabelecidos durante este processo, serviu para abrir novos horizontes de vis ao a respeito da formação do pedagogo.

Também neste mesmo ano iniciei uma parceria de pesquisa com o professor Abdeljalil Akkari da Universidade de Genebra, o qual, nos designou como co-orientadora responsável pelo período de doutorado sanduíche da Ana Sheila Fernandes Costas. Auxiliamos a realizar a coleta de dados e a desenvolver as escritas e trabalhos de pesquisa que depois resultaram em sua tese de doutorado, também em publicações. Esse trabalho foi desenvolvido durante o período de 4 anos, ou seja, de 2010 a 2014.

\section{Banca de pesquisa doutorado em Psicologia 2010 Universidade de Santiago de Compostela - Espanha}

GARCIA, A. C; GIORDANI, E. M; CASTEDO, A. L; LOZANO, E. A. B. A institucionalização do idoso: a autonomia como pressuposto do projeto de vida. 2010. Aluno: Lilian Mary Martins Zieger. Tese (Doutorado em Pós-Graduação) - Universidade de Santiago de Compostela (ES).

A experiência de participação nesta banca de avaliação de doutorado da minha exorientanda de mestrado na Argentina, junto a Universidade de Santiago de Compostela na Espanha, me enriqueceu ainda mais nesta dimensão que venho explicitando, da riqueza da diversidade e aprendizagem de formas mentais de produção de conhecimento. Estando em Santiago de Compostela, pude entrar em contato com professores pesquisadores que possuíam também os mesmos interesses de pesquisas que eu tinha e com isso, ter conhecimento de formas diversas de pensar sobre as mesmas problemáticas. Toda esta bagagem que vinha construindo até então me levou a outra parceria que na verdade existe até hoje, com o professor Akkari da Universidade de Genebra, a qual explicito em seguida.

\section{Projeto de pesquisa entre 2010-2014}

- Registro GAP/CE 027362 - A formação e a profissionalização docente no brasil: entre política educativas, formação e trabalho - Período 25/06/2010 a 31/12/2014. Função: coordenador.

Para o desenvolvimento deste projeto de pesquisa, foi necessário muito empenho pois os padrões da pesquisa desenvolvida em parceria com o Prof. Akkari eram internacionais. Ou seja, era preciso entrar em outra lógica e tradição de elaboração e

\begin{tabular}{|l|l|l|l|l|l|}
\hline Regae: Rev. Gest. Aval. Educ. & Santa Maria & v. 10 & N. especial & e67467, p. 1-60 & 2021
\end{tabular}


desenvolvimento de pesquisas. Além disso, em uma temática que para mim, embora não fosse completamente desconhecida, não tinha o grau de profundidade e nem mesmo competência para discussões de questões teóricas.

Foi preciso vestir a sandália da humildade e aprender a caminhar em um novo terreno, adentrar em outra lógica de pesquisa e formalização de conhecimento. De fato, como possuía um grupo grande de bolsistas, foi possível inserir esta pesquisa no contexto do grupo e, também mobilizar um grande volume de dados empíricos, visto que a maior necessidade e motivação da presença da orientanda do professor Akkari era mesmo a coleta de dados em escolas públicas. A dificuldade em conseguir retorno dos questionários era grande. Por isso, trabalhando com o suporte do grupo de bolsistas que tinha, esta tarefa tornou-se viável e o volume de dados que obtivemos surpreendeu 0 professor Akkari. Acompanhamos a pesquisa na fase da elaboração e defesa do projeto de qualificação de doutorado, depois a coleta de dados e enfim a defesa da tese, na Universidade de Genebra.

Figura 17 -

Registro do projeto $A$ formação e a profissionalização docente no Brasil: entre política educativas, formação e trabalho.

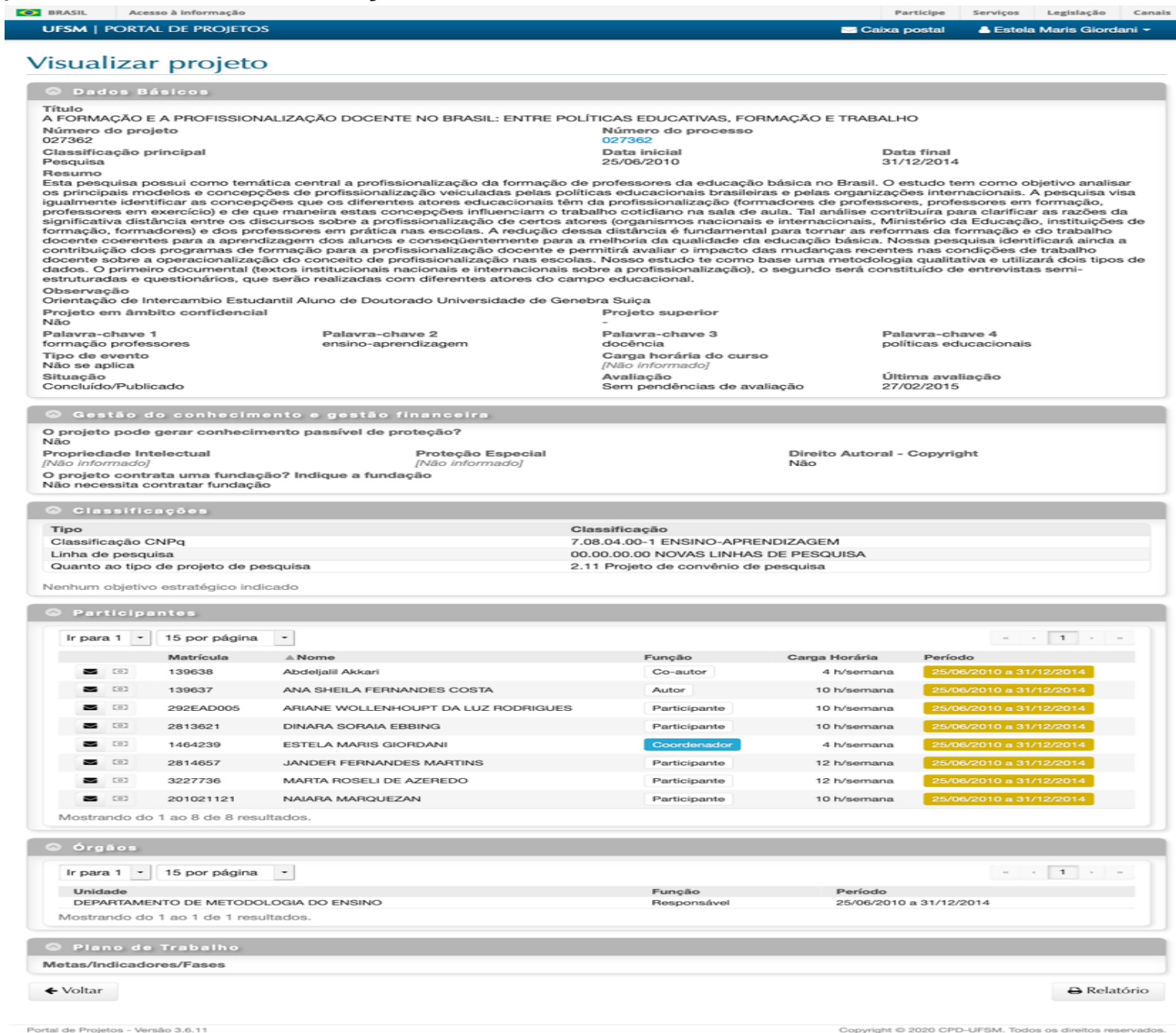

Fonte: Portal de Projetos/UFSM. 
Na viagem por motivo da defesa da tese da Ana Sheila Fernandes, aproveitamos a estada para fazer reuniões com o grupo de pesquisa do professor Akkari e para comunicar a pesquisa que vinha desenvolvendo com a Pedagogia Ontopsicológica. Isso ocorreu em fevereiro de 2014.

No ano de 2010, ministrando a disciplina de Didática para o Curso de EaD em Educação Especial, também publiquei o livro.

Iniciei a pesquisa na AMF e ao mesmo tempo em atividades de extensão, não vinculadas diretamente à UFSM, a partir da temática que segue. Esse projeto esteve e está presente ainda até hoje em meu processo investigativo: GIORDANI, Estela M. et al. Projeto pedagogia Ontopsicológica: promoção e qualificação das práticas escolares. Faculdade Antonio Meneghetti, 2010.

No ano de 2010 ministrando a disciplina de Didática para o Curso de EaD em Educação Especial, também publiquei o livro: GIORDANI, E. M. Didática I. Santa Maria: UAB, 2010, v.1. p.120.

Entre os anos de 2010 - 2012 desenvolvi o projeto de pesquisa $A$ percepção dos problemas das crianças e a pedagogia escolar. Descrição: a pesquisa pretende realizar um levantamento de problemas enfrentados em crianças que frequentam os anos iniciais em algumas escolas municipais de Santa Maria e como estas encaminham tais problemas. Neste sentido, a real intenção é identificar como são percebidos e encaminhados tais problemas: a) o que consideram problemas nas crianças (comportamento, aprendizagem, fracasso, doenças, problemas de articulação fonoarticulatório ou ainda motores, sócio-afetivos etc.); b) com que abordagem a pedagogia escolar, em sua prática, efetivamente enfrenta tais situações; c) quais os medicamentos que as crianças tomam e relativos a que problemas são utilizados pelos alunos. Nosso referencial de fundamentação teórica encontra-se estruturado a partir dos autores que estudam os problemas de aprendizagem e debatem problemas escolares tais como Pain (1985), Ajuriaguerra (1983), Parente \& Renña (1987), Patto (1985), Freitag (1990), Collares e Moysés (1996), Skliar (2003) dentre outros. Pretendemos também analisar as questões sociais que envolvem esses problemas. O estudo parte de uma amostragem inicial em escolas da rede municipal de ensino de Santa Maria. Essa pesquisa será desenvolvida através de uma abordagem quali-quantitativa. Os dados serão coletados através de questionários e observações em sala de aula, adotamos, portanto, a pesquisa de campo para a coleta de dados. Pretendemos ampliar nossa compreensão a respeito de como estão sendo trabalhados os problemas apresentados pelas crianças a partir da concepção de professores e coordenadores pedagógicos e, a partir disso, qual o encaminhamento que se poderia fazer diante essas situações. Esta pesquisa pode auxiliar a evitar problemas ainda hoje desafiam os contextos escolares como o problema da evasão e da repetência. Situação: em andamento; Natureza: pesquisa. Alunos envolvidos: Graduação: (3) / Mestrado acadêmico: (3). Integrantes: Estela Maris Giordani - coordenador / Caroline Jorge Cezar - Integrante / Dinara Soraia Ebbing - Integrante / Jander Fernandes Martins - Integrante / Thais Chivithes Müller - Integrante / Rosana Niederauer Marques - Integrante / Luciane Salmon - Integrante / Luciane Taschetto Integrante. Financiador: Universidade Federal de Santa Maria - Bolsa. 


\section{Orientação de iniciação científica}

No ano de 2010, orientando uma acadêmica da Educação Especial, por meio do meu projeto de pesquisa, pude retornar a minha pesquisa de Mestrado depois de muitos anos para ver se, aquela realidade que havia encontrado naquela época poderia ser ainda verificada ou se haveria modificado e se sim, o que teria modificado. Também foi possível analisar e encontrar outros elementos importantes e presentes no contexto da relação professor-aluno em relação as crianças e suas aprendizagens: Dinara Soraia Ebbing. $A$ percepção dos problemas das crianças e a pedagogia escolar. 2010. Iniciação científica (Licenciatura em Educação Especial) - Universidade Federal de Santa Maria.

Ainda orientei a pesquisa de IC do projeto que desenvolvi junto a UFSC. Posteriormente, essa minha bolsista realizou o seu Mestrado no PPGE da UFSC sendo que o professor orientador foi o professor Lucidio Bianchetti: Evellyn Ledur da Silva. $A$ iniciação científica como processo de formação integral do jovem pesquisador. 2010. Iniciação científica (Licenciatura em Pedagogia) - Universidade Federal de Santa Maria. Inst. financiadora: Fundação de Amparo à Pesquisa do Estado do Rio Grande do Sul.

Ariane Wollenhoupt da Luz Rodrigues. A iniciação científica como processo de formação integral do jovem pesquisador. 2010. Iniciação científica (Licenciatura em Sociologia) - Universidade Federal de Santa Maria. Inst. financiadora: Fundação de Amparo à Pesquisa do Estado do Rio Grande do Sul. Essa foi uma grande pesquisa que desenvolvi, dela também co-orientei uma tese de doutorado, na qual fui banca. Entrar na lógica da formação do pesquisador era minha principal curiosidade, visto que, também enfrentava problemas corriqueiros de como selecionar o bolsista, como formar o bolsista, como manter o bolsista etc. Porque o bolsista chegava desprovido das ferramentas básicas necessárias para a pesquisa, desde aquelas técnicas como ler, compreender, escrever, pesquisar etc. quanto aquelas humanas como disciplina, persistência, capacidade de se colocar problemas, flexibilidade para mudar formas mentais, resiliência, humildade etc. Para mim, entrar nesta problemática era enfrentar o cerne dos problemas formativos, desde o ensino fundamental até o superior. O que implicava também no meu modo de me posicionar como docente e como formadora de novos professores.

Este foi um período e muita busca. Percebi que os colegas, pois a pesquisa foi realizada com professores pesquisadores líderes de grupos de pesquisa, possuíam orientandos de doutorado, mestrado e de iniciação científica, e a pesquisa era justamente de iniciação científica, enfrentavam os mesmos problemas que eu, porém os viviam de formas diferentes. Alguns ou não problematizavam ou talvez não manifestassem perceber esta problemática, mas de algum modo, durante a pesquisa ela sempre aprecia.

De certo modo, apesar de ter problematizado, eu percebia que o processo de iniciação científica formava em parte, mas em uma parte muito pequena o potencial pesquisador. Contudo, é preciso mudar a forma mentis do fazer pesquisa e do fazer a formação do pesquisador. Neste universo das "verdades", dos "deuses" o terreno é muito árduo e talvez pouco fértil. Entendi que era preciso atuar nas categorias de base, voltar as bases, modificar as bases. Então, novamente fui eu buscar novas estradas que, a longo prazo, poderiam levar sementes diferentes de um novo modo de fazer ciência.

Com a bagagem também da escola Ontopsicológica, existia uma outra chave de leitura, contudo, é preciso construir, é preciso tempo, é preciso disciplina e muita persistência para auxiliar a melhorar certas problemáticas que nem mesmo são

\begin{tabular}{|l|l|l|l|l|r|}
\hline Regae: Rev. Gest. Aval. Educ. & Santa Maria & v. 10 & N. especial & e67467, p. 1-60 & 2021 \\
\hline
\end{tabular}


percebidas como problemáticas, visto que, a nossa ciência oficial, ainda opera com os pressupostos da abordagem positivista e que, a dimensão do inconsciente permanece ainda por muitos, negado, relegado e até considerado com 'pseudo-ciência'. Enfim, tudo isso faz parte do universo humano. Então, a história, o tempo e a vanguarda são os preços a serem humildemente pagos para o benefício da própria existência humana no planeta.

\section{Orientações de mestrado em 2010}

Simone Vargas Lunkes. A prática pedagógica do docente supervisor de estágio curricular em psicologia escolar da URI Santo Ângelo. 2010. Dissertação (Mestrado em Docência Universitária) - Universidad Tecnologica Nacional.

\section{Capítulos de livros em 2010}

GIORDANI, E. M. Didática I. Santa Maria: UAB, 2010, v.1. p.120.

Nos anos de 2011 e 2012 ministrando as disciplinas de Didática da Sociologia no Curso de Licenciatura em Sociologia EaD, publiquei os seguintes livros. Livros Publicados para a docência da disciplina de Didática da Sociologia EaD.

GIORDANI, E. M. Didática da Sociologia I. Santa Maria: UAB, 2011 p. 130.

GIORDANI, E. M. Didática da Sociologia II. Santa Maria: UAB, 2012 p. 80.

A experiência de ter escrito um livro de didática foi muito desafiador, por vários motivos, mas explicito neste momento três deles. Em primeiro lugar, porque precisava expor em linguagem escrita as ideias que quando ministro a disciplina presencialmente vou trabalhando com os alunos. E, apesar de parecer simples este movimento, não é. Pois, a docência, na área de nossa expertise, trás nuances de muitos conhecimentos tácitos, e estes, quando as aulas são a distância, de algum modo se torna importante explicitar estes elementos que fazem parte da aquisição das aprendizagens relativas aquele componente curricular. Em segundo lugar porque apesar de ter a expertise, existem muitos autores, livros, textos que considero essenciais, e que embora existam e que faça parte das exigências de leitura dos alunos naquela disciplina, me vi na responsabilidade de também trazer eles dentro da minha escrita, dialogar com ele. Então, me colocava o problema: como eu posso escrever isso se o que o autor escreve está perfeito! Ou seja, se eu escrever pode criar confusão e talvez distorcer. Esse respeito que possuía pelos autores de referência me faziam as vezes superego, e eu tive que transcender a ideia de que aquilo que eu poderia dizer do que eles trabalharam de forma exímia pudesse gerar pobreza ou diminuição e não potência dos elementos teóricos que traziam. E, em terceiro lugar, era para mim algo novo trabalhar com os alunos com textos que foram elaborados por mim e não de outros autores. Neste sentido também tive que quebrar um tabu que possuía. Notei que com a escrita do texto tive que superar muitas barreiras interiores minhas, mas também muitos comodismos e limites que me colocava automaticamente. 


\section{Participação em banca de mestrado em 2011}

Este primeiro trabalho que segue foi orientado por mim: GIORDANI, E. M. Participação em banca de leda Fátima da Silva Brandeburski. La formación contínua de docentes: resignificación de las prácticas pedagógicas como porceso existencial, 2011. (Maestría en Políticas y Administración de la Educación) Universidad Nacional de Tres de Febrero.

SEMINOTTI, N. A; GIORDANI, E. M; CABRAL, P. F. Participação em banca de Ângelo Accorsi Moreira. Aprendizagem nas organizações: a relação entre líder, gestor e colaboradores estratégicos, 2011. (Pós-Graduação em Psicologia) Pontifícia Universidade Católica do Rio Grande do Sul.

PEREIRA, B. A. D; GIORDANI, E. M; MENDES, A. M. M; Participação em banca de Paula da Silva Bazzo. O impacto da consultoria externa no desempenho organizacional: um estudo de multicasos, 2011. (Programa de Pós-Graduação em Administração) Universidade Federal de Santa Maria

\section{Projeto de extensão em 2011}

a) Registro GAP/CE 029947 - I Seminário de Estágios Curriculares do Curso de Pedagogia Noturno - Período 12/07/2011 a 12/07/2011. Função: participante.

b) Registro GAP/CE 030943 - Formação pedagógica para a educação superior Período 01/12/2012 a 31/12/2013. Função: colaborador.

\section{Publicação em revista}

GIORDANI, Estela M; MENDES, Adriane M. M. Pedagogia Ontopsicológica na orientação do estágio dos anos iniciais do ensino fundamental. [S/l]. Nuances: estudos sobre educação. 2011. v. 20. p. 43-62.

\section{Capítulos de livros em 2011}

GIORDANI, E. M; MENDES, A. M. M. A pedagogia ontopsicológica e a formação do pedagogo In: Formação e profissão docente. 1 ed. Araraquara: Junqueira e Marin Ltda./ UNESP, 2011, v.1, p. 206-223.

\section{Participação em concurso público em 2011}

Concurso público para professor adjunto na área de Ciências Humanas, 2011. UFSM.

\section{Orientações de mestrado em 2011}

Sandra Fabiane Kleszta. Políticas públicas e materiais didáticos. 2012. Dissertação (Maestría en Políticas y Administración de la Educación) - Universidad Nacional de Tres de Febrero.

Luciane Salamon. as políticas públicas para juventude para satisfação e necessidade do jovem de 18 a 24 anos na construção da identidade pelo acesso e permanência ao mercado de trabalho: no município de canoas - brasil. 2011. Dissertação (Maestría en Políticas y Administración de la Educación) - Universidad Nacional de Tres de Febrero. 
leda Fatima da Silva Brandeburski. Formação continuada de docentes: o ressignificar das práticas pedagógicas como processo de existencial. 2011. Dissertação (Maestría en Políticas y Administración de la Educación) - Universidad Nacional de Tres de Febrero.

Angelita Vargas Brazil. Formação pedagógica e trabalho escolar do associado da Assers. 2011. Dissertação (Maestría en Políticas y Administración de la Educación) Universidad Nacional de Tres de Febrero.

Simone do Nascimento Vargas. La práctica pedagógica del maestro supervisor de la práctica curricular en psicologia escolar de la URI Santo Ângelo. 2011. Dissertação (Maestría en Docencia Universitaria) - Universidad Tecnologica Nacional.

Figura 18 -

Encargos didáticos no primeiro semestre de 2011: 361 horas aula.

\section{Encargo didático}

\begin{tabular}{|c|c|c|c|c|}
\hline & F Turma & F Disciplina & F Curso & ₹ Encargo didático (h) \\
\hline - & 10 & MEN1200 - DIDÁTICA DA SOCIOLOGIAI & Licenciatura em Sociologia - 526 & 60 \\
\hline - & 11 & EAD1337 - DIDÁTICA DA SOCIOLOGIA II & $\begin{array}{l}\text { Licenciatura Sociologia/Distância/Agudo/RS } \\
-527 \text {.EAD. } 01\end{array}$ & 0 \\
\hline- & 13 & EAD1337 - DIDÁTICA DA SOCIOLOGIA II & $\begin{array}{l}\text { Licenciatura Sociologia/Distância/Restinga } \\
\text { Seca/RS - 527.EAD.03 }\end{array}$ & 0 \\
\hline- & 14 & EAD1337 - DIDÁTICA DA SOCIOLOGIA II & $\begin{array}{l}\text { Licenciatura Sociologia/Distância/Santana } \\
\text { do Livramento/RS - 527.EAD.04 }\end{array}$ & 0 \\
\hline - & $2 \mathrm{~A}$ & $\begin{array}{l}\text { MEN1184 - ESTÁGIO SUPERVISIONADO } \\
\text { NOS ANOS INICIAIS DO ENSINO } \\
\text { FUNDAMENTAL }\end{array}$ & $\begin{array}{l}\text { Pedagogia - Licenciatura Plena Noturno - } \\
627\end{array}$ & 60 \\
\hline - & 10 & MEN855 - METODOLOGIA DO ENSINO "A" & PG em Geomática - Especialização - 897 & 60 \\
\hline - & 11 & MEN855 - METODOLOGIA DO ENSINO "A" & PG Mestrado em Geomática - 888 & 60 \\
\hline- & $2 \mathrm{~N}$ & $\begin{array}{l}\text { MEN1183 - TRABALHO DE CONCLUSÃO } \\
\text { DE CURSO }\end{array}$ & $\begin{array}{l}\text { Pedagogia - Licenciatura Plena Noturno - } \\
627\end{array}$ & 1 \\
\hline - & 13 & $\begin{array}{l}\text { CCP1027 - TRABALHO DE CONCLUSÃO } \\
\text { DE CURSO II }\end{array}$ & Pedagogia - Licenciatura Plena Diurno - 628 & 30 \\
\hline \multicolumn{4}{|c|}{ Encargo didático total: } & 361 \\
\hline \multicolumn{5}{|c|}{ Aviso } \\
\hline
\end{tabular}

Fonte: Portal do professor/UFSM. 
Figura 19 -

Encargos didáticos no segundo semestre de 2011: 526 horas aula.

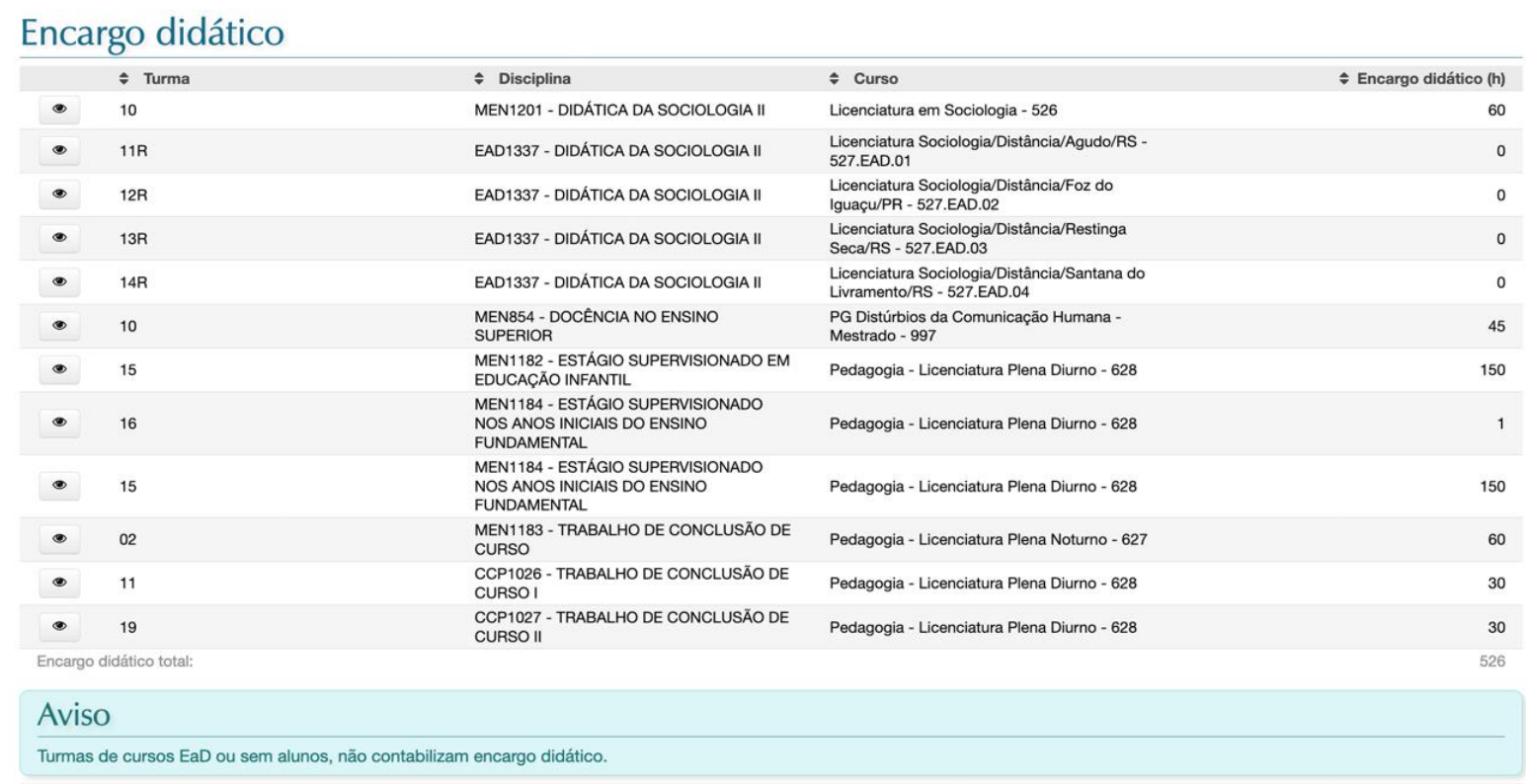

Fonte: Portal do professor/UFSM.

\section{Participação em banca de mestrado em 2012}

GIORDANI, E. M; FELIPPIS, I. C; LAMARRA, N. F. Participação em banca de Angelita Vargas Brazil. Implementacion de las politicas publicas de educacion: una investigacion acerca de la supervision educativa, 2012. (Maestría en Políticas y Administración de la Educación) Universidad Nacional de Tres de Febrero.

GIORDANI, E. M; CENTENO, C. P; LAMARRA, N. F. Participação em banca de Luciane Salamon. Preceitos legais para a construção da identidade profissional do jovem: uma análise documental, 2012. (Maestría en Políticas y Administración de la Educación) Universidad Nacional de Tres de Febrero.

BIDO, D. S; GIORDANI, E. M. Participação em banca de Ana Claudia Valentini Montenegro. A formação de líderes segundo a Ontopsicologia, 2012. (Administração de Empresas) Universidade Presbiteriana Mackenzie.

FREITAS, Deisi Sangoi; GIORDANI, E. M; KRAHE, E. D; WIELEWICKI, H. G. Participação em banca de Rosana Niederauer Marques. A formação pedagógica de docentes supervisores de estágio no curso de Fisioterapia da Universidade Federal de Santa Maria, 2012. (Educação) Universidade Federal de Santa Maria.

STORI, N; GIORDANI, E. M; MARTINS, M. C. F. D. Participação em banca de Carolina Schuskel Miranda. O processo criativo de uma agência publicitária a partir dos princípios da OntoArte e da Ontopsicologia, 2012. (Educação, Arte e História da Cultura) Universidade Presbiteriana Mackenzie. 
Figura 20 -

Encargos didáticos no primeiro semestre de 2012: 390 horas aula.

Encargo didático

\begin{tabular}{|c|c|c|c|c|}
\hline & ث Turma & $\uparrow$ Disciplina & $\uparrow$ Curso & $\rightarrow$ Encargo didático $(\mathrm{h})$ \\
\hline - & $3 \mathrm{C}$ & $\begin{array}{l}\text { MEN1184 - ESTÁGIO SUPERVISIONADO } \\
\text { NOS ANOS INICIAIS DO ENSINO } \\
\text { FUNDAMENTAL }\end{array}$ & Pedagogia - Licenciatura Plena Noturno - 627 & 150 \\
\hline - & $3 B$ & $\begin{array}{l}\text { MEN1184 - ESTÁGIO SUPERVISIONADO } \\
\text { NOS ANOS INICIAIS DO ENSINO } \\
\text { FUNDAMENTAL }\end{array}$ & Pedagogia - Licenciatura Plena Noturno - 627 & 150 \\
\hline - & 10 & MEN855 - METODOLOGIA DO ENSINO "A" & PG em Geomática - Especialização - 897 & 60 \\
\hline - & 03 & $\begin{array}{l}\text { MEN1183 - TRABALHO DE CONCLUSÃO DE } \\
\text { CURSO }\end{array}$ & Pedagogia - Licenciatura Plena Noturno - 627 & 30 \\
\hline \multicolumn{4}{|c|}{ Encargo didático total: } & 390 \\
\hline \multicolumn{5}{|c|}{ Aviso } \\
\hline
\end{tabular}

Fonte: Portal do professor/UFSM.

Figura 21 -

Encargos didáticos no segundo semestre de 2012: 360 horas aula.

Encargo didático

\begin{tabular}{|c|c|c|c|c|}
\hline & F Turma & F Disciplina & - Curso & F Encargo didático (h) \\
\hline - & 16 & EAD1476 - DIDÁTICA DA SOCIOLOGIAI "A" & $\begin{array}{l}\text { Licennciatura Sociologia/Distância/Cachoeira } \\
\text { do Sul/RS - 527.EAD.06 }\end{array}$ & 0 \\
\hline - & 17 & EAD1476 - DIDÁTICA DA SOCIOLOGIA I "A" & $\begin{array}{l}\text { Licenciatura Sociologia/Distância/Picada } \\
\text { Caté/RS - 527.EAD.07 }\end{array}$ & 0 \\
\hline - & 18 & EAD1476 - DIDÁTICA DA SOCIOLOGIA I "A" & $\begin{array}{l}\text { Licenciatura Sociologia/Distância/Quara//RS - } \\
527 . E A D .08\end{array}$ & 0 \\
\hline - & 13_29Turma & EAD1476 - DIDÁTICA DA SOCIOLOGIA I "A" & $\begin{array}{l}\text { Licenciatura Sociologia/Distância/Restinga } \\
\text { Seca/RS - } 527 . E A D .03\end{array}$ & 0 \\
\hline - & 12 & $\begin{array}{l}\text { MEN1182 - ESTÁGIO SUPERVISIONADO EM } \\
\text { EDUCAÇÄO INFANTIL }\end{array}$ & Pedagogia - Licenciatura Plena Diurno - 628 & 150 \\
\hline - & 12 & $\begin{array}{l}\text { MEN1184 - ESTÁGIO SUPERVISIONADO } \\
\text { NOS ANOS INICIAIS DO ENSINO } \\
\text { FUNDAMENTAL }\end{array}$ & Pedagogia - Licenciatura Plena Diurno - 628 & 150 \\
\hline - & 03 & $\begin{array}{l}\text { MEN1183 - TRABALHO DE CONCLUSÃO DE } \\
\text { CURSO }\end{array}$ & Pedagogia - Licenciatura Plena Noturno - 627 & 60 \\
\hline
\end{tabular}

Aviso

Turmas de cursos EaD ou sem alunos, não contabilizam encargo didático.

Fonte: Portal do professor/UFSM.

\section{Projeto de pesquisa em 2013}

Ensino-aprendizagem no estágio curricular do curso de pedagogia: o projeto discutiu os diversos aspectos implicados no processo de ensino-aprendizagem durante os estágios curriculares principalmente em relação aos sujeitos envolvidos: professores (formadores, estagiários, regentes) e alunos (ensino superior, pedagogos e educação básica). Situação: em andamento; Natureza: pesquisa. Alunos envolvidos: Graduação: (4) / Especialização: (2) / Mestrado acadêmico: (1) / Mestrado profissional: (4) / Doutorado: (1). Integrantes: Estela Maris Giordani - coordenador. Número de produções C, T \& A: 6 / Número de orientações: 7. 
Este tema de pesquisa para mim é particularmente caro, porque comecei a desenhar, dentro do quanto possível, um meu método de orientação dos estágios, sem ensinar os princípios da pedagogia Ontopsicológica, mas utilizando estes princípios. Desenvolvi também muitas alternativas didáticas, estratégias de ensino que possuíam a força dos princípios da pedagogia Ontopsicológica. Ou seja, a docência para mim foi e é um campo rico de investigações e indagações, mas também de muitas descobertas e de elaboração de ferramentas. Posso citar algumas destas descobertas que ao longo do tempo fui desenvolvendo, além da leitura inteligente:

- Materiais didáticos: qual seria a lógica de produção dos materiais didáticos no contexto do processo ensino-aprendizagem. Sobre isso entendi, depois de pesquisar, testar, observar, analisar, que, fundamental são os alunos, ao seu próprio modo, construírem seu material didático. Contudo, precisam ter algum "modelo", mas não para copiar e sim para que, por meio do modelo, o professor/estagiário pedagogo consiga comunicar com maior clareza a ideia do resultado. Ou seja, quando o professor/estagiário encaminha para que o aluno/aprendiz produza o material didático ele utilize de objetivos provocativos $^{5}$ (Castanho, 1989).

- Entendi que poderia elaborar um roteiro de relatório para que o mesmo tivesse, em toda a turma os mesmos elementos necessários, não necessariamente em uma mesma ordem.

- Outra descoberta que fui fazendo neste período foi de que, com a orientação da disciplina de estágios, percebi que não adiantava solicitar para as alunas o relatório das práticas que estavam realizando, mas sim quais as aprendizagens que aquelas práticas que faziam remetiam. De todo modo, apesar de incentivar, orientar, revisar, solicitar melhorias, as escritas acabavam sempre se remetendo a relatos, pobres de reflexões.

- Outra aprendizagem neste percurso de orientação de estágio foi de que as acadêmicas deveriam optar, fazer escolhas de princípios teóricos para que pudessem vivenciar a relação entre teoria e prática. Contudo, os estagiários quase sempre esperavam que eu as instrumentalizasse com os meus princípios, as minhas teorias, as minhas compreensões e elaborações. De fato, isso eu fazia, ou seja, deixava claro porque estava orientando e fazendo do modo que estava fazendo, porque ali, imbricada nesta ação havia tal princípio teórico. Ainda, quando iam fazer a sua fundamentação teórica, os princípios os quais escolhiam, não passavam de crenças mascaradas com autores aceitos por grande parte dos professores. Mascarados porque na construção do planejamento também nas ações educativas que estavam conduzindo na verdade não se poderia evidenciar tais princípios. Na maior parte das vezes se notava que aquelas alunas que possuíam maior comprometimento e seriedade e se propunham fazer um trabalho diferenciado, assim o faziam. E aquelas que eram relapsas continuavam a ser relapsas. Ou seja, o período de estágios não era o suficiente para que modificassem algumas posturas, não obstante essas minhas inquietações sempre me acompanhavam e por isso, buscava constantemente alternativas para modificar os esquemas mentais e de ações das estagiárias.

5 Conforme Castanho (1989), em relação ao desempenho do aprendiz, podemos estabelecer tipos diferentes de objetivos: comportamentais, dão o resultado, abertos e provocativos.

\begin{tabular}{l|l|l|l|l} 
Regae: Rev. Gest. Aval. Educ. & Santa Maria & v. 10 & N. especial & e67467, p. 1-60
\end{tabular} 2021 
- Cada vez mais compreendia o quanto era importante os princípios formativos da pedagogia Ontopsicológica, tendo em vista que, nas relações entre adulto e criança, o polo determinante da relação é sempre o mais estruturado, geralmente este é o adulto. Como percebia isso? Quando o estagiário se sentia inseguro em relação à professora regente, em relação a turma ou algum comportamento, por exemplo de agressividade de alguma criança, sendo colocado em xeque mate em sua autoridade. Nestas situações o 'domínio de turma' geralmente tornava-se problemático, então, acabava, como orientadora, trabalhando os aspectos subjetivos do estagiário, explicitando as dinâmicas inconscientes e assim, auxiliando-o a resolver aquela situação. Contudo, aqui sempre havia o limite, que como na UFSM eu não poderia ensinar a Pedagogia Ontopsicológica, porque esta não estava no programa da disciplina, eu sempre dava o remédio, mas não conseguia ensinar como meu estagiário poderia adquirir esta competência.

- Outra importante tomada de consciência foi que a lógica da formação do pedagogo deveria estar presente em toda a formação, em qualquer componente curricular. Ou seja, todos os professores do curso deveriam estar preocupados com o estágio, com as práticas dos acadêmicos do curso de pedagogia, não apenas os professores do estágio. Isso mudaria inclusive a lógica de como os professores constroem a dinâmica da sua disciplina.

- Outra importante compreensão foi que os alunos, em sua prática de estágio, põem em ação os exemplos que tiveram ao longo da formação. Isto é, como no processo formativo sempre tiveram aulas expositivas, centradas no professor, quando estavam preparando a sua aula e desenvolvendo a sua prática, executavam a forma mentis que vivenciaram durante o processo de formação. Como poderia eu modificar estes modelos mentais e comportamentais em um semestre de orientação de estágios dos anos iniciais? Enfim, este dilema sempre me perseguia e cada vez mais, compreendia que num percurso formativo de um pedagogo era fundamental uma unidade de ação, todas as disciplinas e todos os professores do curso construindo um projeto pedagógico real, não aquele apenas que existia no papel. E, para isso, havia muito mesmo a caminhar e que, talvez, isso não poderia ser possível no contexto do curso de Pedagogia da UFSM, tendo em vista os diferentes vieses políticos, teóricos e sobretudo, estruturas administrativas departamentais. O fato de ter sido coordenadora de curso me fez compreender também que os professores ministravam suas disciplinas, mas que pouco se preocupavam em, por meio de sua disciplina, construir o perfil pedagógico do pedagogo.

- Poderia dizer que outra surpresa grande foi que os alunos pouco dominam o corpus teórico básico para um pedagogo. Possuem muitas ideologias, muitos préconceitos, porém não dominam o que significa educação, pedagogia, ensino, aprendizagem, avaliação, etc. Percebia que sempre manifestavam que o estágio era 0 momento de 'colocar em prática o que haviam aprendido na teoria'. E, no momento em que iniciei a investigar então, quais eram estes elementos que haviam aprendido, dei-me conta, de que havia apenas 0 meme $^{6}$ da existência dos mesmos, mas que na realidade

${ }^{6}$ Meme significa uma informação que não possui reversibilidade com o real (Meneghetti, 2012). 
estes não faziam parte do domínio teórico ou conceitual dos alunos. E, na verdade, nunca cobrei que teriam que compartilhar dos mesmos meus autores ou conjunto de saberes. Pelo contrário, que devessem explicitar e construir os seus, porque não tem como relacionar teoria com a prática se não existe nem mesmo teoria.

- Ouvia muito os professores falarem que na prática a teoria era outra. Este fato me incomodava muito. Não vou me adentrar muito nesta questão, mas vou trazer uma reflexão apenas. Caso isso fosse uma verdade haveria duas teorias, a teoria da teoria e a teoria da prática. Mas, na realidade, não há nem uma e nem outra, ou seja, não há o domínio da teoria e nem mesmo na prática não existe a compreensão de quais elementos teóricos estão em ação. Visto que, se existisse teoria da prática esta explicaria alguma coisa, e não era isso que se percebia.

\section{Projeto de extensão em 2013}

a) Registro GAP/CE 033688 - Formação e desenvolvimento pessoal e profissional de professores do ensino básico" - Período 05/07/2013 a 20/12/2013. Função: participante.

- Registro GAP/CE 035592 - Semana Acadêmica do Centro de Educação - Período 14/10/2013 a 18/10/2013. Função: colaborador.

GIORDANI, Estela M; RAMBO, Márcia Cristiane. Leitura como instrumento de construção do sujeito histórico. Revista Latino-Americana de História, v. 2, n. 6, 2013, p. 1145-1157.

GIORDANI, Estela M. Pedagogia Ontopsicológica e o processo ensinoaprendizagem. IN: MEIRELLES, M; RAIZER, L; PEREIRA, L. H (org.). O ensino de sociologia no RS: repensando o lugar da sociologia. Porto Alegre: Evangraf, 2013, p. 245261.

Nos anos de 2013-2014 desenvolvi o seguinte projeto de pesquisa: Processo de ensino aprendizagem na educação básica por meio da técnica de leitura compreensiva. Situação: concluído; Natureza: pesquisa. Alunos envolvidos: Graduação: (2) / Especialização: (2). Integrantes: Estela Maris Giordani - coordenador / Márcia Cristiane Rambo - Integrante / Daniele Barros Vargas Furtado - Integrante. Número de produções C, T \& A: 11 / Número de orientações: 6.

\section{Orientações de iniciação científica}

Márcia Cristiane Rambo. Processo de ensino-aprendizagem na educação básica por meio da técnica da leitura compreensiva. 2013. Iniciação científica (licenciatura em Pedagogia) - Universidade Federal de Santa Maria. Inst. financiadora: UFSM.

Daniele Barros Vargas Furtado. Processo de ensino-aprendizagem na educação básica por meio da técnica da leitura inteligente no ensino fundamental. 2014. Iniciação científica (Pedagogia) - Universidade Federal de Santa Maria. Inst. financiadora: UFSM 
Figura 22 -

Encargos didáticos no primeiro semestre de 2013: 420 horas aulas.

Encargo didático

\begin{tabular}{|c|c|c|c|c|}
\hline & : Turma & F Disciplina & $=$ Curso & F Encargo didático (h) \\
\hline - & 16.50 & EAD1476 - DIDATICA DA SOCIOLOGIA I "A" & $\begin{array}{l}\text { Licenciatura sociologialdistancia/Cachoeitra do } \\
\text { Sul/RS 527.7ADD.06 }\end{array}$ & 0 \\
\hline - & 17.50 & EAD 1476 - DIDÁTICA DA SOCIOLOGIAI "A" & $\begin{array}{l}\text { Licenciatura Sociologiadistañncia/Picada Caté/RS - } \\
\text { 527.EAD.07 }\end{array}$ & 0 \\
\hline - & 18.50 & EAD1476 - DIDÁTICA DA SOCIOLOGIAI "A" & $\begin{array}{l}\text { Licenciatura Sociologia/Distância/Quarai/RS - } \\
527 . E A D .08\end{array}$ & 0 \\
\hline - & 13.50 & EAD1476 - DIDÁTICA DA SOCIOLOGIAI "A" & $\begin{array}{l}\text { Licenciaturar Sociologialaristância/Restinga } \\
\text { Seca/AS - 527. EAD.03 }\end{array}$ & 0 \\
\hline - & 16 & EAD1477 - DIDÁTICA DA SOCIOLOGIA II "A" & $\begin{array}{l}\text { Licenciatura Sociologialdistancia/Cachoeira do } \\
\text { SulRS } 527.7 A D \text { D.06 }\end{array}$ & 0 \\
\hline - & 17 & EAD1477 - DIDÁTICA DA SOCIOLOGIA II "A" & 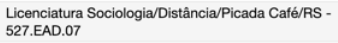 & 0 \\
\hline - & 18.50 & EAD 1477 - DIDÁTICA DA SOCIOLOGIA II "A" & $\begin{array}{l}\text { Licenciaitura Sociologiadistatancia/Quaraí/RS - } \\
\text { 527.:ADD.08 }\end{array}$ & 0 \\
\hline - & 18 & EAD1477 - DIDÁTICA DA SOCIOLOGIAII" "A" & $\begin{array}{l}\text { Licenciatura Sociologia/Distancia/Quarai/RS - } \\
527 . A A D .08\end{array}$ & 0 \\
\hline - & 13 & EAD1477 - DIDÁTICA DA SOCIOLOGIA II "A" & $\begin{array}{l}\text { Licenciatura Sociologialistância/Restinga } \\
\text { SecalRS - 527.EAD.03 }\end{array}$ & 0 \\
\hline • & 04 & 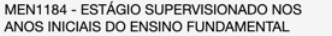 & Pedagogia - Licenciatura Plena Noturno - 627 & 150 \\
\hline - & 11 & MENBS5 - METODOLOGIA DO ENSINO "A" & PG em Geomática - Especializaçăo - 897 & 60 \\
\hline - & 05B & 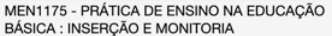 & Pedagogia - Licenciatura Plena Noturno - 627 & 90 \\
\hline • & 04B & $\begin{array}{l}\text { MEN1183 - TRABALHO DE CONCLUSÃO DE } \\
\text { CURSO }\end{array}$ & Pedagogia - Licenciatura Plena Noturno - 627 & 60 \\
\hline - & 53 & $\begin{array}{l}\text { CCP1026 - TRABALHO DE CONCLUSÃ̃ DE } \\
\text { CURSOI }\end{array}$ & Pedagogia - Licenciatura Plena Diurno - 628 & 30 \\
\hline • & 37 & $\begin{array}{l}\text { CCP1026 - TRABALLO DE CONCLUSĀO DE } \\
\text { CUROI }\end{array}$ & Pedagogia - Licenciatura Plena Diurno - 628 & 0 \\
\hline & 20 & $\begin{array}{l}\text { CCP1027 - TRABALHO DE CONCLUSĀO DE } \\
\text { CURSO I" }\end{array}$ & Pedagogia - Licenciatura Plena Diurno - 628 & 30 \\
\hline \multicolumn{4}{|c|}{ Encargo didático total: } & 420 \\
\hline \multicolumn{4}{|c|}{ Aviso } & \\
\hline
\end{tabular}

Almprimir

Fonte: Portal do professor/UFSM.

Figura 23 -

Encargos didáticos no segundo semestre de 2013: 361 horas aulas.

Encargo didático

\begin{tabular}{|c|c|c|c|c|}
\hline & F Turma & F Disciplina & F Curso & - Encargo didático (h) \\
\hline- & 0805 & EAD1476 - DIDÁTICA DA SOCIOLOGIA I "A" & $\begin{array}{l}\text { Licenciatura Sociologia/Distância/Quarai/RS - } \\
527 . E A D .08\end{array}$ & 0 \\
\hline- & 0305 & EAD1476 - DIDÁTICA DA SOCIOLOGIA I "A" & $\begin{array}{l}\text { Licenciatura Sociologia/Distância/Restinga } \\
\text { Seca/RS - 527.EAD.03 }\end{array}$ & 0 \\
\hline - & 0405 & EAD1337 - DIDATICA DA SOCIOLOGIA II & $\begin{array}{l}\text { Licenciatura Sociologia/Distância/Santana do } \\
\text { Livramento/RS - 527.EAD.04 }\end{array}$ & 0 \\
\hline - & 0605 & EAD1477 - DIDÁTICA DA SOCIOLOGIA II "A" & $\begin{array}{l}\text { Licenciatura Sociologia/Distância/Cachoeira } \\
\text { do Sul/RS - 527.EAD.06 }\end{array}$ & 0 \\
\hline - & 0805 & EAD1477 - DIDÁTICA DA SOCIOLOGIA II "A" & $\begin{array}{l}\text { Licenciatura Sociologia/Distância/Quarai/RS - } \\
527 . \text { EAD.08 }\end{array}$ & 0 \\
\hline - & 12 & $\begin{array}{l}\text { MEN1 } 182 \text { - ESTÁGIO SUPERVISIONADO EM } \\
\text { EDUCAÇĀO INFANTIL }\end{array}$ & Pedagogia - Licenciatura Plena Diurno - 628 & 150 \\
\hline - & 12 & $\begin{array}{l}\text { MEN1184 - ESTÁGGIO SUPERVIIIONADO } \\
\text { NOS ANOS INICIAIS DO ENSINO } \\
\text { FUNDAMENTAL }\end{array}$ & Pedagogia - Licenciatura Plena Diurno - 628 & 150 \\
\hline - & 1009 & EFM832 - TÓPICOS ESPECIAIS & PG-M em Enfermagem - 1009 & 1 \\
\hline \multicolumn{5}{|c|}{ Aviso } \\
\hline
\end{tabular}

Fonte: Portal do professor/UFSM.

\section{Capítulos de livros em 2013}

GIORDANI, E. M. Antonio Meneghetti e a Sociologia. In: Ensino de Sociologia: diálogos entre Pedagogia e Sociologia.1 ed. Porto Alegre: Laviecs/Evangraf, 2013, p. 81102. 
GIORDANI, E. M; RAMBO, M. C. Leitura e construção do conhecimento em sala de aula: aprendendo a forma humana de ser In: O Pibid na URI. vol. III. 1 ed. Frederico Westphalen: URI - Frederico Westphalen, 2013, v. III, p. 310-319.

GIORDANI, E. M. Pedagogia Ontopsicológica e o processo ensino-aprendizagem In: O ensino de sociologia no RS. 1 ed. Porto Alegre: Evangraf/Laviecs, 2013, v.1, p. 245262.

Nestas publicações entro em muitas reflexões e questões teóricos estão a fazer parte das minhas práticas de pesquisa e na docência dos componentes curriculares. Especialmente porque comecei a desenvolver mais os conceitos e compreensões da pedagogia Ontopsicológica nas minhas atividades como docente, também na pesquisa.

\section{Participação em concurso público em 2013}

Banca examinadora para seleção pública - professor substituto área de Didática, Metodologias, Práticas e Estágio na Educação Infantil e nos Anos Iniciais do Ensino Fundamental, 2013. UFSM

Banca examinadora para seleção pública - professor substituto área de Metodologia, Didática e Prática de Ensino da Língua Portuguesa na Educação Básica, 2013. UFSM.

Banca examinadora para seleção pública para professor substituto na área de Educação Musical: Metodologia de Ensino de Educação Infantil ao Ensino Médio, 2013. UFSM.

Comissão de avaliação de seleção de processos de pedidos de ingresso/reingresso para o curso de Pedagogia Licenciatura Plena Noturno da UFSM, 2013. UFSM.

\section{Projeto de pesquisa 2014}

No ano de 2014 iniciei um projeto de pesquisa o qual, ainda hoje, por conta de seus desdobramentos, desenvolvo estudos. Ainda hoje, 2020, possuo uma orientanda do Mestrado em Educação e Ciências no Uruguai pela Atenas College University: Processo e aquisição da leitura inteligente através da metodologia da pesquisa em séries finais do ensino fundamental, cuja mestranda é Laís Corrêa Martins Azambuja.

A ideia desta pesquisa nasceu na docência do mestrado em Educação em Itajaí em 2000. Depois, cada vez mais foi se colocando como necessária em todas as minhas atividades docentes, visto que, percebia a fragilidade da proficiência da leitura de textos acadêmicos. Além disso, orientando estágios do ensino fundamental, essa necessidade ficou muito mais relevante, visto que, observava que, tanto as minhas orientandas de estágio não sabiam fazer a leitura compreensiva quanto os seus alunos de primeiro a quinto ano tinham o mesmo problema. Então, me coloquei o objetivo de estudar mais a lógica dos processos de leitura e de construir ferramentas didáticas que pudessem auxiliar os alunos a ler e a realizar a leitura e a compreensão com capacidade reflexiva, apropriando-se de modo eficaz e autônomo do conteúdo do texto lido. Foi um longo percurso, mas como tudo, é preciso depois a paciência histórica para implementar realizando a formação dos acadêmicos. Percebia, que apesar de ser uma ideia avançada e muito eficiente, por demandar maior dedicação e paciência, era ligeiramente descartada. Isso me fez sofrer muitas vezes, mas continuei e deste percurso da técnica da leitura inteligente, hoje desenvolvi um método de escrita de texto de gênero informativo, o qual explicito mais adiante. 
Processo de ensino-aprendizagem por meio da técnica da leitura inteligente (20142020): nossa proposta de pesquisa/ação é investigar o desenvolvimento de uma técnica de leitura compreensiva, desenvolvida por nós ao longo do tempo da experiência. Essa técnica é resultado do diálogo com autores que desenvolvem técnicas de leitura, contudo, esta foi sendo adaptada para o trabalho no processo ensino-aprendizado na educação básica. Consideramos a capacidade da leitura compreensiva uma das habilidades essenciais à aprendizagem escolar humana e sobretudo à formação de novas gerações de pesquisadores. Investigaremos nas práticas de sala de aula de professores que aplicam esta técnica e depois quais são os resultados que levam a contribuir com as várias aprendizagens escolares que necessitam diretamente da compreensão de textos diversos. Situação: em andamento; Natureza: pesquisa. Alunos envolvidos: Graduação: (2) / Especialização: (1). Integrantes: Estela Maris Giordani - Coordenador / Márcia Cristiane Rambo - Integrante / Daniele Barros Vargas Furtado - Integrante / Elisiana Maria Cassol Tanscheit - Integrante.

Deste projeto algumas produções nasceram assim como orientações de TCC: GIORDANI, Estela M; FURTADO, Daniele B. V. Leitura inteligente e o processo de ensino-aprendizagem nos anos finais do ensino fundamental em uma escola do campo. JAI 2014. Prolicen 2014.

Aprendizagem da leitura inteligente no ensino fundamental e médio (2014-2020): o projeto teve origem a partir das atividades de orientação de estágio curricular no curso de Pedagogia. Visando a necessidade de compreender mais a fundo como se desenvolve na educação básica o ensino de uma habilidade essencial para a formação de jovens pesquisadores, a leitura compreensiva. $O$ domínio da linguagem científica por meio da apropriação da leitura compreensiva no processo de formação de professores é um tema que ainda merece atenção nas pesquisas acadêmicas. Ao longo da atividade profissional, exercendo a formação de professores nos deparamos com situações que estão relacionadas não ao domínio da língua padrão, mas do domínio da linguagem científica justamente pela carência de técnicas e métodos de leitura compreensiva. Os professores também dizem que os alunos vêm com vícios de escrita e possuem problemas com o uso correto da língua portuguesa. Todo esse contexto nos fez desenvolver durante o processo de formação do pedagogo no estágio uma nova forma de orientar para enfrentar o problema do despreparo do professor, auxiliando o professor a enfrentar este problema de modo que tenha em mãos recursos técnicos que os auxiliam. Neste sentido, ao longo do tempo, desenvolvemos a técnica da leitura inteligente especificamente desenvolvida para textos de gênero informativo. Essa técnica demostrou-se eficiente nas pesquisas já desenvolvidas no ano de 2013 e 2014 por meio do Prolicen 2013/2014 o qual foi desenvolvido no contexto dos anos iniciais do ensino fundamental. Os resultados desse projeto foram apresentados em diversos eventos de cunho regional, nacional e internacional, publicado em um artigo em revista de cunho científica indexada avaliada como qualis B3. Também foram realizadas oficinas gratuitas à professores em processos de formação inicial e continuada. Tendo em vista esse percurso já desenvolvido pelo projeto nos anos iniciais do ensino fundamental e médio, neste ano, propomos no Prolicen 2015 a continuidade desse projeto, mas investigando as séries finais do ensino 
fundamental e o ensino médio. Situação: Em andamento; Natureza: Pesquisa. Alunos envolvidos: Graduação: (4) / Especialização: (1) Integrantes: Estela Maris Giordani Coordenador / Elisiana Maria Cassol Tanscheit - Integrante / Daiane Maira Soccal Integrante / Josiane Aparecida Martim - Integrante.

Figura 24 -

Encargos didáticos no primeiro semestre de 2014: 511 horas aula.

Encargo didático

\begin{tabular}{|c|c|c|c|c|}
\hline & $\approx$ Turma & † Disciplina & $\approx$ Curso & F Encargo didático (h) \\
\hline - & 11 & $\begin{array}{l}\text { MEN1182 - ESTÁGIO SUPERVISIONADO EM } \\
\text { EDUCAÇĀO INFANTLL }\end{array}$ & Pedagogia - Licenciatura Plena Diurno - 628 & 150 \\
\hline - & 05B & $\begin{array}{l}\text { MEN1184 - ESTÁGIO SUPERVIIIONADO } \\
\text { NOS ANOS INICIAIS DO ENSINO } \\
\text { FUNDAMENTAL }\end{array}$ & Pedagogia - Licenciatura Plena Noturno - 627 & 150 \\
\hline - & $05 \mathrm{~A}$ & $\begin{array}{l}\text { MEN1184 - ESTÁGIO SUPERVIIIONADO } \\
\text { NOS ANOS INICIAIS DO ENSINO } \\
\text { FUNDAMENTAL }\end{array}$ & Pedagogia - Licenciatura Plena Noturno - 627 & 150 \\
\hline - & 05_C & $\begin{array}{l}\text { MEN1183 - TRABALHO DE CONCLUSÃ̃ DE } \\
\text { CURSO }\end{array}$ & Pedagogia - Licenciatura Plena Noturno - 627 & 1 \\
\hline - & 05_I & $\begin{array}{l}\text { MEN1183 - TRABALHO DE CONCLUSÃO DE } \\
\text { CURSO }\end{array}$ & Pedagogia - Licenciatura Plena Noturno - 627 & 60 \\
\hline \multicolumn{4}{|c|}{ Encargo didático total: } & 511 \\
\hline \multicolumn{5}{|c|}{ Aviso } \\
\hline
\end{tabular}

Fonte: Portal do professor/UFSM.

Figura 25 -

Encargos didáticos no segundo semestre de 2014: 330 horas aula.

Encargo didático

\begin{tabular}{|c|c|c|c|c|}
\hline & F Turma & - Disciplina & - Curso & ₹ Encargo didático $(\mathrm{h})$ \\
\hline - & 14 & $\begin{array}{l}\text { MEN1182 - ESTÁGIO SUPERVISIONADO EM } \\
\text { EDUCAÇĀO INFANTLL }\end{array}$ & Pedagogia - Licenciatura Plena Diurno - 628 & 150 \\
\hline - & 14 & $\begin{array}{l}\text { MEN1184 - ESTÁGIO SUPERVISIONADO } \\
\text { NOS ANOS INCIAIS DO ENSINO } \\
\text { FUNDAMENTAL }\end{array}$ & Pedagogia - Licenciatura Plena Diurno - 628 & 150 \\
\hline - & 16 & $\begin{array}{l}\text { MEN1184 - ESTÁGIO SUPERVISIONADO } \\
\text { NOS ANOS INICIIIS DO ENSINO } \\
\text { FUNDAMENTAL }\end{array}$ & Pedagogia - Licenciatura Plena Diurno - 628 & 0 \\
\hline$\rightarrow$ & 26 & $\begin{array}{l}\text { CCP1027 - TRABALHO DE CONCLUSÃO DE } \\
\text { CURSO II }\end{array}$ & Pedagogia - Licenciatura Plena Diurno - 628 & 30 \\
\hline \multicolumn{4}{|c|}{ Encargo didático total: } & 330 \\
\hline \multicolumn{5}{|c|}{ Aviso } \\
\hline
\end{tabular}

Fonte: Portal do professor/UFSM.

Das pesquisas desenvolvidas sobre a leitura inteligente cheguei a necessidade de elaborar uma técnica de escrita. Eu entendo que é muito mais do que isso, percebi que se trata de colocar em prática o método investigativo, de como fazer pesquisas, fazer 0 registro destas pesquisas de modo autoral. Isto é, de por meio deste método ser capaz de construir conhecimentos, entrar na dialética com o que existe, mas colocar-se na relação com o que existe de modo a construir uma novidade de reflexão. Este percurso ainda não foi registrado ou publicado, mas está sendo testado e colocado em prática em diversas situações de minha prática profissional: nos relatórios de estágio, nas orientações de TCC, graduação e especialização, e dissertação de mestrado e doutorado, nas 
orientações das práticas pedagógicas nos estágios dos alunos, nas orientações de construção de textos nos componentes curriculares que ministro, nos projetos de extensão CriAre, financiado pela Fundação Antonio Meneghetti em parceria com o curso de Pedagogia da Antonio Meneghetti Faculdade.

\section{Capítulos de livros em 2014}

GIORDANI, E. M. Como educar crianças de seis a doze anos In: Uma nova pedagogia para a sociedade futura.1 ed. Recanto Maestro: Ontopsicológica Editora Universitária, 2014, v.1, p. 15-26.

FURTADO, D. B. V; GIORDANI, E. M. Leitura Inteligente e o Processo de Apropriação do Conhecimento In: Práticas educativas e as interfaces da qualidade. 1 ed. Santa Maria: CE/UFSM, 2014, v.1, p. 32-43.

GIORDANI, E. M. Pedagogia Ontopsicológica: a formação integral da pessoa protagonista responsável. In: Ontopsicologia: ciência interdisciplinar.1 ed. Santa Maria: OntoEd, 2014, p. 1-29.

\section{Participação concurso público em 2014}

Banca examinadora da seleção pública para contratação de professor substituto na área da Educação Matemática, 2014. UFSM

\section{Participação em banca de mestrado 2014}

BOER, N; WEYH, C. B; GIORDANI, E. M; SCHEID, N. M. J. Participação em banca de Karla Ziembowicz. Impactos sócio-ambientais e percepções da comunidade sobre a Barragem da Usina Hidrelétrica (UHE) São José, Cerro Largo, RS, 2014. (P.P.G em Ensino Científico e Tecnológico) Universidade Regional Integrada do Alto Uruguai e das Missões).

BElOCHIO, C. R; GIORDANI, E. M; BEINEKE, V; HeTteWER, A. L. M. E. L. Participação em banca de Viviane Elias Portela. Projeto Flauta na Educação Musical: um estudo com entrevistas em São João do Polêsine - RS, 2014. (Programa de PósGraduação em Educação) Universidade Federal de Santa Maria).

No ano de 2014 fui designada por três vezes para substituir temporariamente a direção do Centro de Educação, assumindo assim a função de diretora do Centro de Educação. Este fato me honrou de modo particular, visto que fui designada pela confiança que existia em relação a minha pessoa na relação com a gestão. Ou seja, apesar de tantas controvérsias em relação a minha pessoa eu de fato, me era reputado valor por parte das lideranças, isso me encorajou e me deu mais responsabilidade.

\section{Projeto de extensão em 2015}

- Registro GAP/CE 035878 - UFSM e pacto nacional pela alfabetização na idade certa: área de educação matemática - Período 15/09/2015 a 14/12/2017. Função: participante.

- Registro GAP/CE 039396 - Educação no século XXI: enfocando os desafios e cultura de convergência digital na formação de professores e na educação básica Período 02/03/2015 a 31/07/2015. Função: participante. 
- Registro GAP/CE 040781 - Formação e desenvolvimento pessoal e profissional docente - Período 08/05/2015 a 04/12/2015. Função: instrutor.

\section{Projetos de pesquisa em 2015}

a) Registro GAP/CE 039737 - Processo de ensino-aprendizagem por meio da técnica da leitura inteligente - Período 20/03/2015 a 20/12/2018. Função: coordenador.

b) Registro GAP/CE 039901 - Ensino-aprendizagem na no estágio curricular em anos iniciais dos cursos de pedagogia diurno e noturno a partir dos fundamentos da Pedagogia Ontopsicológica - Período 01/04/2015 a 31/03/2020. Função: coordenador.

c) Ensino-aprendizagem no estágio curricular em anos iniciais dos cursos de Pedagogia diurno e noturno a partir dos fundamentos da Pedagogia Ontopsicológica (2015-2020): na busca pela efetivação dos fins da educação contidas no art. $2^{\circ}$ da LDB o pleno desenvolvimento do educando, seu preparo para o exercício da cidadania e sua qualificação para o trabalho? temos encontrado cada vez mais respaldo nos princípios da pedagogia Ontopsicológica. Em nossa trajetória docente temos percebido a pertinência desta nova abordagem pedagógica e por isso, os seus princípios têm sido utilizados na formação dos pedagogos nos cursos de pedagogia diurno e noturno no contexto da disciplina de Estágio Curricular Supervisionado em anos iniciais do ensino fundamental na Universidade Federal de Santa Maria. Especificamente estudamos as aprendizagens construídas por meio das orientações alicerçadas nestes fundamentos no período de realização do estágio. Objetiva-se estudar e desenvolver uma metodologia de ensino de orientação de estágio a partir dos princípios da pedagogia Ontopsicológica assim como estudar os resultados atingidos na realização da experiência de orientação do estágio a partir destes princípios. A metodologia escolhida é pesquisa qualitativa, visto que, neste caso o objeto de estudo é a prática do próprio pesquisador. Espera-se com a pesquisa identificar as contribuições da pedagogia Ontopsicológica na formação de pedagogos e contribuir com a melhoria da qualidade do ensino tanto no contexto formativo da universidade como na educação básica. Situação: em andamento; Natureza: pesquisa. Alunos envolvidos: Graduação: (1). Integrantes: Estela Maris Giordani - coordenador / Gabriela Mombelli - Integrante.

d) Processo de ensino-aprendizagem por meio da técnica da leitura inteligente (2015-2020): com a técnica da leitura inteligente busca-se compreender como ela favorece a aquisição de conhecimentos no contexto da aprendizagem de sala de aula. Situação: em andamento; Natureza: pesquisa. Integrantes: Estela Maris Giordani coordenador / Elisiana Maria Cassol Tanscheit - Integrante.

e) Ensino-aprendizagem no estágio curricular em anos iniciais dos cursos de Pedagogia diurno e noturno a partir dos fundamentos da Pedagogia Ontopsicológica(2015-2020): na busca pela efetivação dos fins da educação contidas no art. $2^{\circ}$ da LDB o pleno desenvolvimento do educando, seu preparo para o exercício da cidadania e sua qualificação para o trabalho? temos encontrado cada vez mais respaldo nos princípios da pedagogia Ontopsicológica. Em nossa trajetória docente temos percebido a pertinência desta nova abordagem pedagógica e por isso, os seus princípios têm sido utilizados na formação dos pedagogos nos cursos de pedagogia diurno e noturno no contexto da disciplina de Estágio Curricular Supervisionado em anos iniciais do ensino fundamental na Universidade Federal de Santa Maria. Especificamente

\begin{tabular}{|l|l|l|l|l|l|}
\hline Regae: Rev. Gest. Aval. Educ. & Santa Maria & v. 10 & N. especial & e67467, p. 1-60 & 2021 \\
\hline
\end{tabular} 
estudamos as aprendizagens construídas por meio das orientações alicerçadas nestes fundamentos no período de realização do estágio. Objetiva-se estudar e desenvolver uma metodologia de ensino de orientação de estágio a partir dos princípios da pedagogia Ontopsicológica assim como estudar os resultados atingidos na realização da experiência de orientação do estágio a partir destes princípios. A metodologia escolhida é pesquisa qualitativa, visto que, neste caso o objeto de estudo é a prática do próprio pesquisador. Espera-se com a pesquisa identificar as contribuições da pedagogia Ontopsicológica na formação de pedagogos e contribuir com a melhoria da qualidade do ensino tanto no contexto formativo da universidade como na educação básica. Situação: em andamento; Natureza: pesquisa. Alunos envolvidos: Graduação: (1). Integrantes: Estela Maris Giordani - coordenador / Gabriela Mombelli - integrante.

\section{Participação concurso público em 2015}

Comissão examinadora da seleção pública para contratação de professor substituto área Didática, Metodologia, Práticas e Estágios em Artes Visuais da Ed. Inf. ao Ensino Médio, 2015 Universidade Federal de Santa Maria

Comissão examinadora da seleção pública para contratação de professor substituto área Didática, Metodologia, Práticas e Estágios em Artes Visuais da Ed. Inf. ao Ensino Médio, 2015. Universidade Federal de Santa Maria.

Comissão examinadora da seleção pública para contratação de professor substituto área Didática, Metodologia, Práticas e Estágios na Educação Infantil e Anos Iniciais do Ensino Fundamental, 2015. Universidade Federal de Santa Maria

Comissão examinadora da seleção pública para contratação de professor substituto na área de Metodologia, Didática e Prática de Ensino de Língua Portuguesa na Educação Básica, 2015. Universidade Federal de Santa Maria.

\section{Participação em banca de mestrado 2015}

SCHEID, N. M. J; GIORDANI, E. M; ZANON, L. B. Participação em banca de Cristiane Barbosa de Oliveira. A acessibilidade de deficientes visuais aos conceitos básicos de química do ensino médio, 2015. (P.P.G em Ensino Científico e Tecnológico) Universidade Regional Integrada do Alto Uruguai e das Missões)

SCHEID, N. M. J; GIORDANI, E. M; WEYH, C. B. Participação em banca de Angélica Pozzer. Apostila alternativa de libras como recurso didático para a inclusão de alunos surdos em escola regular, 2015. Universidade Regional Integrada do Alto Uruguai e das Missões).

\section{Capítulos de livros em 2015}

GIORDANI, E. M; FURTADO, D. B. V. Estágio curricular supervisionado: teoria e prática em uma turma do $1^{\circ}$ ano do ensino fundamental de uma escola do campo In: Aprendizagem e acessibilidade: travessias do aprender na universidade. 1 ed. Santa Maria: UFSM, 2015, p. 293-306. 
Figura 26 -

Encargos didáticos no primeiro semestre de 2015: 360 horas aula.

Encargo didático

\begin{tabular}{|c|c|c|c|c|}
\hline & $\triangleq$ Turma & - Disciplina & - Curso & - Encargo didático (h) \\
\hline - & $06 \mathrm{~A}$ & $\begin{array}{l}\text { MEN1184 - ESTÁGIO SUPERVISIONADO } \\
\text { NOS ANOS INICIAIS DO ENSINO } \\
\text { FUNDAMENTAL }\end{array}$ & Pedagogia - Licenciatura Plena Noturno - 627 & 150 \\
\hline - & 06 & $\begin{array}{l}\text { MEN1183 - TRABALHO DE CONCLUSÃO DE } \\
\text { CURSO }\end{array}$ & Pedagogia - Licenciatura Plena Noturno - 627 & 60 \\
\hline \multicolumn{4}{|c|}{ Encargo didático total: } & 360 \\
\hline \multicolumn{5}{|c|}{ Aviso } \\
\hline
\end{tabular}

Fonte: Portal do professor/UFSM.

Figura 27 -

Encargos didáticos no segundo semestre de 2015: 510 horas aula.

Encargo didático

\begin{tabular}{|c|c|c|c|c|}
\hline & - Turma & - Disciplina & - Curso & F Encargo didático (h) \\
\hline - & 13 & $\begin{array}{l}\text { MEN1182 - ESTÁGIO SUPERVISIONADO EM } \\
\text { EDUCAÇÃO INFANTIL }\end{array}$ & Pedagogia - Licenciatura Plena Diurno - 628 & 150 \\
\hline - & 07 & $\begin{array}{l}\text { MEN1182 - ESTÁGIO SUPERVISIONADO EM } \\
\text { EDUCAÇÃO INFANTIL }\end{array}$ & Pedagogia - Licenciatura Plena Noturno - 627 & 150 \\
\hline - & 13 & $\begin{array}{l}\text { MEN1184 - ESTÁGIO SUPERVISIONADO } \\
\text { NOS ANOS INICIAIS DO ENSINO } \\
\text { FUNDAMENTAL }\end{array}$ & Pedagogia - Licenciatura Plena Diurno - 628 & 150 \\
\hline - & 07 & $\begin{array}{l}\text { MEN1242 - SEMINÁRIO DE ESTUDOS } \\
\text { PEDAGOGICOS }\end{array}$ & Pedagogia - Licenciatura Plena Noturno - 627 & 60 \\
\hline - & 06 & $\begin{array}{l}\text { MEN1183 - TRABALHO DE CONCLUSÃO DE } \\
\text { CURSO }\end{array}$ & Pedagogia - Licenciatura Plena Noturno - 627 & 0 \\
\hline \multicolumn{4}{|c|}{ Encargo didático total: } & 510 \\
\hline \multicolumn{5}{|c|}{ Aviso } \\
\hline
\end{tabular}

Fonte: Portal do professor/UFSM.

Em 2015 ingressei no programa Pacto Nacional pela Alfabetização na Idade Certa: área da Educação Matemática. Essa foi uma experiência que me marcou muito. Eu fui formadora juntamente com a professora Dilce Cardoso, no município de Caxias do Sul. Este foi um projeto que participei até o ano de 2017.

Aprendi e reaprendi muitas coisas. Quando me candidatei foi porque eu desejava me aprimorar na orientação dos estágios, entendi que se eu dominasse com maior profundidade as áreas das metodologias, e dentre as prioritárias estava a educação matemática, eu poderia melhorar significativamente a minha prática de orientadora de estágios dos anos iniciais. De fato, foi o que aconteceu. Com essa experiência eu mais aprendi do que ensinei e o que aprendi depois fui incorporando na orientação dos estágios. Da reflexão deste trabalho nasceu um artigo que teve a publicação posteriormente no ano de 2018.

No ano de 2016 iniciei um novo percurso. comecei um projeto de formação de pais, uma escola de pais, no contexto das redes sociais: facebook e YouTube. Comecei a produzir conteúdos de orientação para pais. Com conteúdos 100\% online e 100\% gratuitos. Minha fanpage dra. Estela Giordani chegou a ter mais de 71 mil curtidas e o 
meu canal do YouTube tem hoje 3 mil e 800 inscritos. Na sequência pode-se ver os prints das páginas da internet. Estes projetos trabalhei muito intensamente nos anos de $2016 \mathrm{e}$ 2017. No ano de 2018 e 2019 quase parei, embora ainda continuei de certa forma trabalhando nele.

Figura 28 -

Fanpage no Facebook.

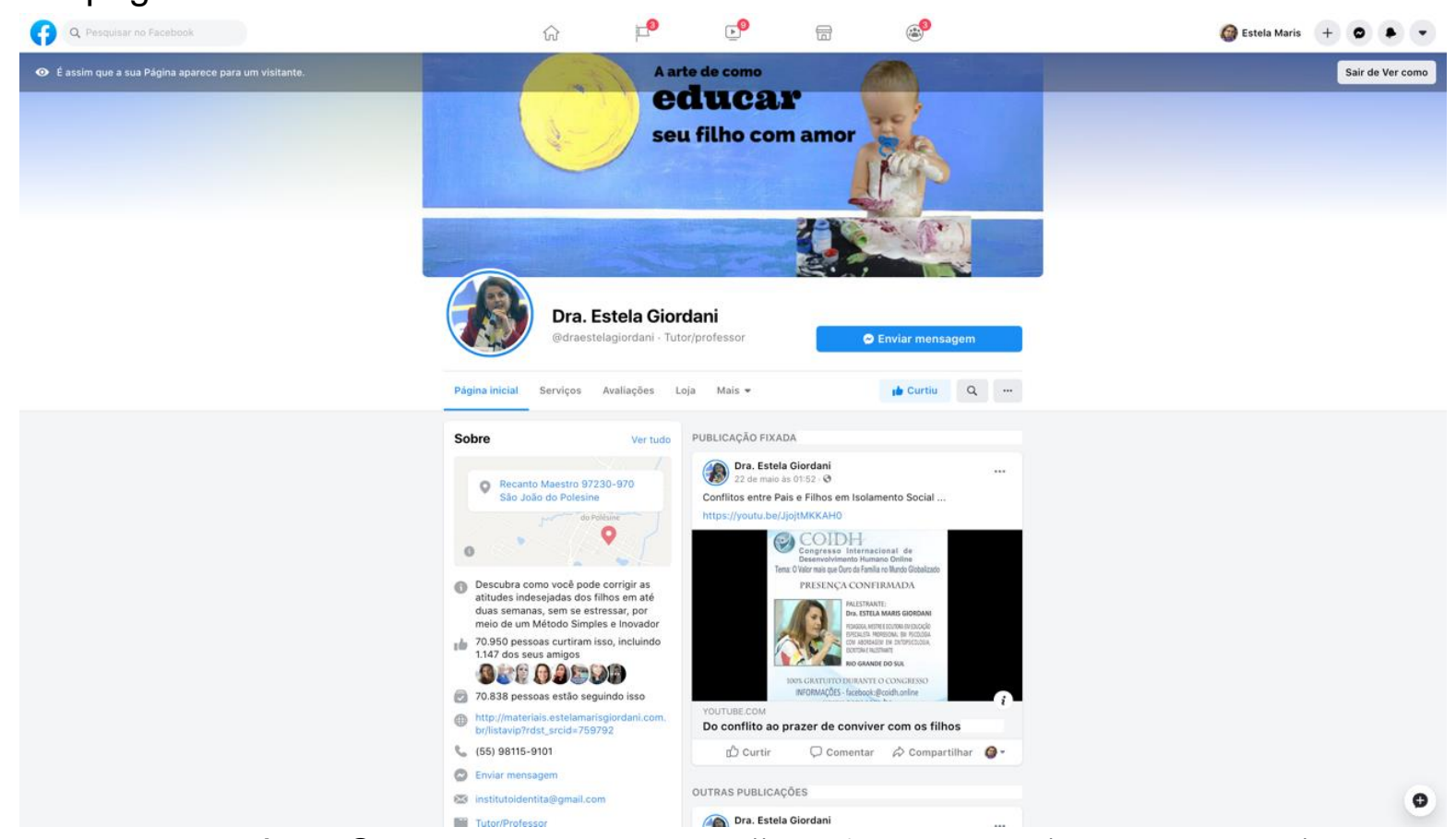

Fonte: Print da página @dra.estelagiordani - https://www.facebook.com/draestelagiordani/.

Também derivado deste trabalho foi a publicação de artigos em jornais, revistas e blogs. Eram textos escritos a partir dos vídeos, mas sempre reelaborados em outra linguagem. Estes artigos constam no lattes e durante dois anos praticamente foram publicados todas as semanas e por vezes em mais de um jornal regional. Houve épocas em que se publicava em cinco jornais regionais. Esse trabalho apenas formalizei no ano de 2017 como projeto de extensão na UFSM.

\section{Projeto de extensão em 2016}

a) Registro GAP/CE 044539 - UFSM e pacto nacional pela alfabetização na idade certa: nterdisciplinaridade no ciclo de alfabetização - Período - 01/11/2016 a 31/12/2017. Função: participante

\section{Capítulos de livros em 2016}

GIORDANI, E. M; MARTIM, J. A; TANSCHEIT, E. M. C; FURTADO, D. B. V. A leitura inteligente e a produção de texto no Programa Mais Educação. BORIN, Marta Rosa; COSTAS, Fabiane Adela Tonetto (org.). In: Educação na escola de tempo integral. Tubarão: Copiart, 2016, v.1, p. 151-178. 
GIORDANI, E. M; FURTADO, D. B. V. A leitura inteligente e o processo de apropriação do conhecimento a partir da Pedagogia Ontopsicológica In: Ontopsicologia Ciência Interdisciplinar. 1 ed. São João do Polêsine: Fundação Antonio Meneghetti, 2016, v. II, p. 155-178.

\section{Participação em banca de mestrado em 2016}

LUNA, J. M. F; FERREIRA, Valéria Silva; GIORDANI, E. M. Participação em banca de Angelita de Fátima Weigert. $A$ influência de projetos e ações de incentivo à leitura no desempenho do Ideb, 2016. (Programa de Pós-Graduação Mestrado Em Educação) Universidade do Vale do Itajaí

GIORDANI, E. M; FRANZIN, R. F; BOER, N. Participação em banca de Luciana Carlize Juliani Smolski. Terminologias matemáticas na tradução para a Libras: um instrumento mediador do processo de ensino de geometria plana e espacial, 2016. (P.P.G em Ensino Científico e Tecnológico) Universidade Regional Integrada do Alto Uruguai e das Missões).

Nesta última banca, da Luciana Carlize, eu co-orientei seu trabalho, praticamente exerci a função de orientadora visto que, tenho a formação na área da Educação Especial. Foi um trabalho muito inovador da mestranda, pois ela, exercendo a função de professora de Matemática, percebeu que a linguagem de Libras não possui definido todos os termos, especialmente no ensino de Matemática faltavam muitos vocábulos, que na verdade eram muito mais do que vocábulos e sim conceitos. Além disso, nesta língua existem muitas variações o que torna ainda muito mais complexo o trabalho do professor de matemática ao trabalhar com aluno que possui uma perda auditiva.

Gabriela Mombelli. Pedagogia Ontopsicológica na orientação de estágio curricular em anos iniciais do curso de Pedagogia. 2016. Iniciação científica (Curso de Pedagogia (Noturno) - Universidade Federal de Santa Maria. Inst. financiadora: UFSM.

Figura 29 -

Encargos didáticos primeiro semestre de 2016: 160 horas aula.

Encargo didático

\begin{tabular}{|c|c|c|c|c|}
\hline & - Turma & † Disciplina & $\neq$ Curso & ₹ Encargo didático (h) \\
\hline - & 13 & $\begin{array}{l}\text { MEN1182 - ESTÁGIO SUPERVISIONADO EM } \\
\text { EDUCAÇĀO INFANTIL }\end{array}$ & Pedagogia - Licenciatura Plena Diurno - 628 & 150 \\
\hline - & 07 & $\begin{array}{l}\text { MEN1182 - ESTÁGIO SUPERVISIONADO EM } \\
\text { EDUCAÇĀOO INFANTIL. }\end{array}$ & Pedagogia - Licenciatura Plena Noturno - 627 & 150 \\
\hline - & 13 & $\begin{array}{l}\text { MEN1184 - ESTÁGIO SUPERVIIIONADO } \\
\text { NOS ANOS INICIAIS DO ENSINO } \\
\text { FUNDAMENTAL }\end{array}$ & Pedagogia - Licenciatura Plena Diurno - 628 & 150 \\
\hline - & 07 & $\begin{array}{l}\text { MEN1242 - SEMINÁRIO DE ESTUDOS } \\
\text { PEDAGÓGICOS }\end{array}$ & Pedagogia - Licenciatura Plena Noturno - 627 & 60 \\
\hline - & 06 & $\begin{array}{l}\text { MEN1183 - TRABALHO DE CONCLUSÃO DE } \\
\text { CURSO }\end{array}$ & Pedagogia - Licenciatura Plena Noturno - 627 & 0 \\
\hline \multicolumn{4}{|c|}{ Encargo didático total: } & 510 \\
\hline \multicolumn{5}{|c|}{ Aviso } \\
\hline
\end{tabular}

Fonte: Portal do professor/UFSM. 
Figura 30 -

Encargos didáticos segundo semestre de 2016: 300 horas aula.

Encargo didático

\begin{tabular}{|c|c|c|c|c|}
\hline & † Turma & † Disciplina & $\uparrow$ Curso & A Encargo didático (h) \\
\hline - & 16 & $\begin{array}{l}\text { MEN1182 - ESTÁGIO SUPERVISIONADO EM } \\
\text { EDUCAÇÄO INFANTIL }\end{array}$ & Pedagogia - Licenciatura Plena Diurno - 628 & 150 \\
\hline - & 16 & $\begin{array}{l}\text { MEN1184 - ESTÁGIO SUPERVISIONADO } \\
\text { NOS ANOS INICIAIS DO ENSINO } \\
\text { FUNDAMENTAL }\end{array}$ & Pedagogia - Licenciatura Plena Diurno - 628 & 150 \\
\hline \multicolumn{4}{|c|}{ Encargo didático total: } & 300 \\
\hline \multicolumn{5}{|c|}{ Aviso } \\
\hline
\end{tabular}

Fonte: Portal do professor/UFSM.

\section{Projeto de extensão em 2017}

a) Registro GAP/CE 045286 - Princípios da Pedagogia Ontopsicológica na educação familiar, escolar e clínica. Período - 16/01/2017 a 31/12/2021. Função: coordenador

\section{Projeto de pesquisa em 2017}

Princípios da pedagogia ontopsicológica na educação familiar, escolar e clínica: temos como perspectiva disseminar e ampliar os conhecimentos adquiridos através da pesquisa científica ancorados nos princípios da pedagogia Ontopsicológica e as contribuições que estas práticas têm proporcionado no desenvolvimento cognitivo, psicomotor, emocional e intelectual nas crianças. $O$ intuito é auxiliar famílias, professores e psicopedagogos a encontrarem soluções para as dificuldades no processo educativo das crianças (filhos/alunos), a fim de solucionar e evitar os comportamentos indesejados, bem como prevenir tais comportamentos e sobretudo, possibilitar o desenvolvimento das crianças a partir da sua identidade de natureza, seu Em Si ôntico. Os fundamentos teóricos que sustentam as práticas são da Pedagogia Ontopsicológica (Meneghetti, 2014; Vidor, 2014) e as especificações desta teoria aplicada aos contextos escolares e familiar desenvolvidos por Giordani ao longo de sua prática profissional e de sua pesquisa. As relações humanas são fundamentais porque por meio delas se estabelecem as práticas pedagógicas tanto na escola quanto na família. A metodologia adotada pelo programa segue esta nova abordagem pedagógica testada em sua eficiência por mais de 40 anos. Buscamos estender e compreender o impacto do trabalho que está sendo desenvolvido por meio de conteúdos gratuitos nas mídias sociais na internet - Facebook, Youtube, Instagran e PodsCast - e em atividades presenciais para pais, professores e psicopedagogos. O programa de extensão tem uma duração de 5 anos e durante a sua implementação estão previstos subprojetos referentes a: 1) formação de pais; b) formação de professores e psicopedagogos. No programa prevemos: cursos, palestras, workshops, grupos de estudo, produção de material didático, pesquisa, artigos e livro. Situação: em andamento; Natureza: pesquisa. Integrantes: Estela Maris Giordani - coordenador. 
Também, deste trabalho surgiram diversos outros desdobramentos, como palestras, cursos, trabalhos de assessoria e consultoria pais, assim como outros vídeos, textos de jornais. Este foi um trabalho intenso muito vivo, na medida em que eu ia agindo os temas e questões emergiam e então assim foi se construindo um corpo de relações entre teoria e prática de orientação de pais. Muito estudei, pesquisei sobre quais eram os outros autores que também faziam a orientação de pais. Mas, de fato, a partir da perspectiva da abordagem da Pedagogia Ontopsicológica era a primeira vez que acontecia este trabalho.

$\mathrm{Na}$ metade do ano de 2017 também comecei a coordenar o curso de Pedagogia da AMF. A partir de então uma nova etapa de vida iniciou e se intensificou os estudos e a pesquisa sobre a Pedagogia Ontopsicológica.

Pedagogia e política: os princípios da pedagogia ontopsicológica aplicadas na relação indivíduo-sociedade: a equação da relação indivíduo e sociedade sempre esteve no âmago dos grandes pensadores da pedagogia, desde as mais antigas civilizações até os dias atuais. Os resultados das interações sociais, seus limites e possibilidades são sustentados sempre por específicas formas de fazer pedagogia e seus resultados se colhem constantemente no contexto social. Nos interessa aprofundar, por meio da pesquisa, tendo como principal fundamento a Pedagogia Ontopsicológica (Meneghetti, 2014), quais são os principais princípios que inseridos na gestão pública podem qualificar e favorecer o humanismo na direção do direito de ser pessoa e ao mesmo tempo em que este ser humano pode ser um exímio contribuinte ao composto social. A pergunta é, qual é a arte de ser pessoa e ao mesmo tempo cidadão? Deste modo, a difícil relação o indivíduo está para a sociedade assim como a sociedade está para o indivíduo, pode ser revisada em seus modos de compreensão ao longo da história e ao mesmo tempo, podemos agregar as novas contribuições da pesquisa Pedagogia Ontopsicológica aos novos tempos e desafios da educação e da gestão pública. Entendemos que fazer Política ou Gestão Pública é também um modo de fazer Pedagogia, pois toda a diretriz pública implicará uma sucessão de eventos e de comportamentos individuais e coletivos que condicionarão eventos sucessivos. Entrar nos fundamentos dos princípios causais da gestão que privilegia um real contributo de valor aos humanos e posteriormente às organizações públicas e conceber e promover os meios para a sua eficiente implementação é a intenção inderrogável desta pesquisa. Na pesquisa desenvolveremos prioritariamente as temáticas Pedagogia e Política; Protagonismo Responsável; Pedagogia para o Líder; Pedagogia para a Criatividade. Como abordagem de pesquisa optamos pela abordagem qualitativa cuja metodologia é processo racional indutivodedutivo conciliando as novidades científicas complementares da ciência Ontopsicológica: campo semântico, Em Si ôntico, monitor de deflexão. Situação: em andamento; Natureza: Pesquisa. Alunos envolvidos: Graduação: (2) / Especialização: (4) / Mestrado acadêmico: (0) / Mestrado profissional: (2) / Doutorado: (2). Integrantes: Estela Maris Giordani coordenador.

\section{Orientação de iniciação científica}

Elisiana Maria Cassol Tanscheit. Princípios da pedagogia Ontopsicológica na educação familiar, escolar e clínica. 2017. Iniciação científica, Curso de Pedagogia licenciatura plena noturno - Universidade Federal de Santa Maria. 
Paula Savegnago Rossato. Pedagogia Ontopsicológica na formação dos docentes do curso de pedagogia da Faculdade Antonio Meneghetti. 2017. Iniciação científica, Curso de Pedagogia licenciatura plena noturno - Universidade Federal de Santa Maria.

\section{Capítulos de livros em 2017}

GIORDANI, E. M; TANSCHEIT, E. M. C; SOCCAL, D. M. Leitura inteligente no ensino médio: aplicação dos princípios da Pedagogia Ontopsicológica In: Ontopsicologia Ciência Interdisciplinar. 1 ed. São João do Polêsine: Fundação Antonio Meneghetti, 2017, v. III, p. 271-296.

GIORDANI, E. M; MOMBELLI, G. Pedagogia Ontopsicológica na prática de orientação de estágio em Pedagogia - Anos Iniciais In: Ontopsicologia Ciência Interdisciplinar. 1 ed. São João do Polêsine: Fundação Antonio Meneghetti, 2017, v. III, p. 225-248.

GIORDANI, E. M. Pedagogia Ontopsicológica para pais e educadores. In: Pedagogia Contemporânea: responsabilidade e formação do jovem para a sociedade futura. 1 ed. São João do Polêsine: Ontopsicológica Editora Universitária, 2017, v.1, p. 59-68.

Estas produções foram todas derivadas do projeto de extensão acerca dos princípios da Pedagogia Ontopsicológica aplicadas na educação familiar, escolar e clínica.

Figura 31 -

Encargos didáticos no primeiro semestre de 2017: 277,5 horas aula.

Encargo didático

\begin{tabular}{|c|c|c|c|c|}
\hline & $\uparrow$ Turma & - Disciplina & $\leqslant$ Curso & † Encargo didático (h) \\
\hline - & 627 & $\begin{array}{l}\text { MEN1182 - ESTÁGIO SUPERVISIONADO EM } \\
\text { EDUCAÇÃO INFANTIL }\end{array}$ & Pedagogia - Licenciatura Plena Noturno - 627 & 37.5 \\
\hline - & $08 \mathrm{C}$ & $\begin{array}{l}\text { MEN1184 - ESTÁGIO SUPERVISIONADO } \\
\text { NOS ANOS INICIAIS DO ENSINO } \\
\text { FUNDAMENTAL }\end{array}$ & Pedagogia - Licenciatura Plena Noturno - 627 & 112.5 \\
\hline - & 09B & $\begin{array}{l}\text { MEN1175 - PRÁTICA DE ENSINO NA } \\
\text { EDUCAČÃO BÁSICA : INSERÇÃOO E } \\
\text { MONITORIA }\end{array}$ & Pedagogia - Licenciatura Plena Noturno - 627 & 90 \\
\hline - & $08 \mathrm{E}$ & $\begin{array}{l}\text { MEN1183 - TRABALHO DE CONCLUSÃO DE } \\
\text { CURSO }\end{array}$ & Pedagogia - Licenciatura Plena Noturno - 627 & 37.5 \\
\hline
\end{tabular}

AviSO

Fonte: Portal do professor/UFSM. 
Figura 32 -

Encargos didáticos no segundo semestre de 2017: 345 horas aula.

Encargo didático

\begin{tabular}{|c|c|c|c|c|}
\hline & F Turma & † Disciplina & $\rightarrow$ Curso & F Encargo didático $(\mathrm{h})$ \\
\hline - & 31 & MEN1197 - DIDÁTICA & $\begin{array}{l}\text { Licenciatura em Educação Especial - Noturno } \\
-637\end{array}$ & 60 \\
\hline - & 13 & $\begin{array}{l}\text { MEN1182 - ESTÁGIO SUPERVISIONADO EM } \\
\text { EDUCAÇĀOO INFANTIL }\end{array}$ & Pedagogia - Licenciatura Plena Diurno - 628 & 105 \\
\hline - & 13 & $\begin{array}{l}\text { MEN1184 - ESTÁGIO SUPERVISIONADO } \\
\text { NOS ANOS INICIAIS DO ENSINO } \\
\text { FUNDAMENTAL }\end{array}$ & Pedagogia - Licenciatura Plena Diurno - 628 & 105 \\
\hline - & 10 & $\begin{array}{l}\text { MEN1184 - ESTÁGIO SUPERVISIONADO } \\
\text { NOS ANOS INICIAIS DO ENSINO } \\
\text { FUNDAMENTAL }\end{array}$ & Pedagogia - Licenciatura Plena Noturno - 627 & 37.5 \\
\hline - & 09 & $\begin{array}{l}\text { MEN1183 - TRABALHO DE CONCLUSĀO DE } \\
\text { CURSO }\end{array}$ & Pedagogia - Licenciatura Plena Noturno - 627 & 37.5 \\
\hline
\end{tabular}

\section{Aviso}

Turmas de cursos EaD ou sem alunos, não contabilizam encargo didático.

Fonte: Portal do professor/UFSM.

\section{Projeto de pesquisa em 2018}

a) Registro GAP/CE 051953 - Trabalho pedagógico e qualidade: avaliação docente pelo discente/2018 - 20/05/2018 a 30/06/2019. Função: participante.

\section{Participação em comissões 2018}

a) Comissão examinadora da seleção pública para contratação de professor substituto área de Ensino de Inglês do MEN, 2018. Universidade Federal de Santa Maria.

b) Comissão examinadora da seleção pública para contratação de professor substituto do MEN - Área Educação Física, 2018. Universidade Federal de Santa Maria.

\section{Capítulos de livros em 2018}

CARDOSO, D; GIORDANI, E. M; BOLZAN, M. T. Aquisição de conteúdos matemáticos: uma reflexão sobre a experiência do PACTO. In: Formação de Professores Alfabetizadores no contexto do Pacto Nacional pela Alfabetização na Idade Certa. 1 ed. Caxias do Sul: Caxias, 2018, v.1, p. 169-184.

GIORDANI, E. M. Pedagogia e política. Revista Alta Política. Porto Alegre, 2018, p. 26-27. 
Figura 33 -

Encargos didáticos no primeiro semestre de 2018: 412,5 horas.

Encargo didático

\begin{tabular}{|c|c|c|c|c|}
\hline & A Turma & F Disciplina & F Curso & \& Encargo didático (h) \\
\hline - & 10 & $\begin{array}{l}\text { MEN1182 - ESTÁGGIO SUPERVISIONADO EM } \\
\text { EDUCACÄO INFANTLL }\end{array}$ & Pedagogia - Licenciatura Plena Diurno - 628 & 97.5 \\
\hline - & 10 & $\begin{array}{l}\text { MEN1184 - ESTÁGIO SUPERVIIIONADO } \\
\text { NOS ANOS INICAIIS DO ENSINO } \\
\text { FUNDAMENTAL }\end{array}$ & Pedagogia - Licenciatura Plena Diurno - 628 & 97.5 \\
\hline - & 09A & $\begin{array}{l}\text { MEN1184 - ESTÁGIO SUPERVIIIONADO } \\
\text { NOS ANOS INICIAIS DO ENSINO } \\
\text { FUNDAMENTAL }\end{array}$ & Pedagogia - Licenciatura Plena Noturno - 627 & 112.5 \\
\hline - & 11 & $\begin{array}{l}\text { MEN1169 - ORGANIZAÇÃO DA AÇĀO } \\
\text { PEDAGÓGICA }\end{array}$ & Pedagogia - Licenciatura Plena Diurno - 628 & 60 \\
\hline- & $09 B$ & $\begin{array}{l}\text { MEN1183 - TRABALHO DE CONCLUSĀO DE } \\
\text { CURSO }\end{array}$ & Pedagogia - Licenciatura Plena Noturno - 627 & 37.5 \\
\hline & ESTELA & $\begin{array}{l}\text { CCP1027 - TRABALHO DE CONCLUSÃO DE } \\
\text { CURSO II }\end{array}$ & Pedagogia - Licenciatura Plena Diurno - 628 & 7.5 \\
\hline \multicolumn{4}{|c|}{ Encargo oidático total: } & 412.5 \\
\hline \multicolumn{5}{|c|}{ Aviso } \\
\hline
\end{tabular}

Fonte: Portal do professor/UFSM.

Figura 34 -

Encargos didáticos no segundo semestre de 2018:180 horas aula.

Encargo didático

\begin{tabular}{|c|c|c|c|c|}
\hline & A Turma & A Disciplina & * Curso & ₹ Encargo didático (h) \\
\hline - & 13 & $\begin{array}{l}\text { MEN1184 - ESTÁGIO SUPERVISIONADO } \\
\text { NOS ANOS INICIAIS DO ENSINO } \\
\text { FUNDAMENTAL. }\end{array}$ & Pedagogia - Licenciatura Plena Diurno - 628 & 67.5 \\
\hline$\rightarrow$ & $11 \mathrm{~N}$ & $\begin{array}{l}\text { MEN1169 - ORGANIZAÇÃO DA AÇÃO } \\
\text { PEDAGÓGICA }\end{array}$ & Pedagogia - Licenciatura Plena Noturno - 627 & 60 \\
\hline$\rightarrow$ & $10 \mathrm{~N}$ & $\begin{array}{l}\text { MEN1242 - SEMINÁRIIO DE ESTUDOS } \\
\text { PEDAGOOGICOS }\end{array}$ & Pedagogia - Licenciatura Plena Noturno - 627 & 30 \\
\hline - & 101 & $\begin{array}{l}\text { MEN1183 - TRABALHO DE CONCLUSÃO DE } \\
\text { CURSO }\end{array}$ & Pedagogia - Licenciatura Plena Noturno - 627 & 7.5 \\
\hline & ESTELA & $\begin{array}{l}\text { CCP1027 - TRABALHO DE CONCLUSÃ̃O DE } \\
\text { CURSO II }\end{array}$ & Pedagogia - Licenciatura Plena Diurno - 628 & 15 \\
\hline \multicolumn{4}{|c|}{ Encargo oidático total: } & 180 \\
\hline \multicolumn{4}{|c|}{ Aviso } & \\
\hline
\end{tabular}

Fonte: Portal do professor/UFSM.

\section{Projeto de pesquisa em 2019}

a) Registro GAP/CE 051949 - Indicadores de qualidade do Centro de Educação da UFSM - Período 01/05/2019 a 15/07/2019. Função: participante.

\section{Capítulos de livros 2019}

GIORDANI, E. M; TANSCHEIT, E. M. C; VARGAS, D. Pedagogia Ontopsicológica nas oficinas de aprendizagens do Projeto CriAre. In: Ontopsicologia Ciência Interdisciplinar. 1 ed. São João do Polêsine: Fundação Antonio Meneghetti, 2019, v. IV, p. 255-268.

MOMBELLI, G; SILVA, F. B. K; GIORDANI, E. M. Princípios da pedagogia Ontopsicológica na educação de um filho. In: Ontopsicologia Ciência Interdisciplinar. 1 ed. São João do Polêsine: Fundação Antonio Meneghetti, 2019, v. IV, p. 219-234.

GIORDANI, E. M. O político pedagogo. Revista Alta Política. Porto Alegre, v.1 2019, p. 26-27. 
Figura 35 -

Encargos didáticos no primeiro semestre de 2019: 330 horas.

Encargo didático

\begin{tabular}{|c|c|c|c|c|}
\hline & F Turma & O Disciplina & F Curso & F Encargo didático (h) \\
\hline - & 100 & $\begin{array}{l}\text { MEN1 } 184 \text { - ESTÁGIO SUPERVISIONADO } \\
\text { NOS ANOS INICIAIS DO ENSINO } \\
\text { FUNDAMENTAL }\end{array}$ & Pedagogia - Licenciatura Plena Noturno - 627 & 90 \\
\hline - & $10 \mathrm{~A}$ & $\begin{array}{l}\text { MEN1184 - ESTÁGIO SUPERVISIONADO } \\
\text { NOS ANOS INICIAIS DO ENSINO } \\
\text { FUNDAMENTAL }\end{array}$ & Pedagogia - Licenciatura Plena Noturno - 627 & 60 \\
\hline - & 11 & $\begin{array}{l}\text { MEN1169 - ORGANIZAÇÃO DA AÇÃO } \\
\text { PEDAGÓGICA }\end{array}$ & Pedagogia - Licenciatura Plena Diurno - 628 & 60 \\
\hline - & R032 & $\begin{array}{l}\text { MEN1169 - ORGANIZAÇÃO DA AÇÃO } \\
\text { PEDAGÓGICA }\end{array}$ & Pedagogia - Licenciatura Plena Noturno - 627 & 0 \\
\hline - & 11 & $\begin{array}{l}\text { MEN1280 - ORGANIZAÇÃOO DA AÇĀO } \\
\text { PEDAGÓGICA A }\end{array}$ & Pedagogia - Licenciatura Plena Diurno - 628 & 45 \\
\hline - & 11 & $\begin{array}{l}\text { CCP1028 - PED VII - SABERES E FAZERES } \\
\text { NA EDUCAÇĀO BÁSICA }\end{array}$ & Pedagogia - Licenciatura Plena Diurno - 628 & 30 \\
\hline - & 11 & $\begin{array}{l}\text { CCP1032 - SEMINÁRIO INTEGRADOR II: } \\
\text { DESAFIOS DO PEDAGOGO NO CAMPO DA } \\
\text { DIVERSIDADE }\end{array}$ & Pedagogia - Licenciatura Plena Diurno - 628 & 30 \\
\hline - & 10L & $\begin{array}{l}\text { MEN1183 - TRABALHO DE CONCLUSÃO DE } \\
\text { CURSO }\end{array}$ & Pedagogia - Licenciatura Plena Noturno - 627 & 7.5 \\
\hline - & ESTELA_M & $\begin{array}{l}\text { CCP1026 - TRABALHO DE CONCLUSÃO DE } \\
\text { CURSO I }\end{array}$ & Pedagogia - Licenciatura Plena Diurno - 628 & 7.5 \\
\hline \multicolumn{4}{|c|}{ Encargo didático total: } & 330 \\
\hline \multicolumn{5}{|c|}{ Aviso } \\
\hline
\end{tabular}

Fonte: Portal do professor/UFSM.

Figura 36 -

Encargos didáticos no segundo semestre de 2019: 270 horas.

Encargo didático

\begin{tabular}{|c|c|c|c|c|}
\hline & - Turma & - Disciplina & F Curso & - Encargo didático (h) \\
\hline - & 31 & MEN1197 - DIDÁTICA & $\begin{array}{l}\text { Licenciatura em Educação Especial - Noturno } \\
\text { - } 637\end{array}$ & 60 \\
\hline - & 11 & MEN1270 - DIDÁTICA A & Pedagogia - Licenciatura Plena Diurno - 628 & 60 \\
\hline - & 13 & $\begin{array}{l}\text { MEN1184 - ESTÁGIO SUPERVISIONADO } \\
\text { NOS ANOS INICIAIS DO ENSINO } \\
\text { FUNDAMENTAL }\end{array}$ & Pedagogia - Licenciatura Plena Diurno - 628 & 105 \\
\hline - & $11 \mathrm{~N}$ & $\begin{array}{l}\text { MEN1242 - SEMINÁRIO DE ESTUDOS } \\
\text { PEDAGÓGICOS }\end{array}$ & Pedagogia - Licenciatura Plena Noturno - 627 & 0 \\
\hline - & 10 & MEN874 - TÉCNICAS DE ENSINO & $\begin{array}{l}\text { PG em Administração Pública - Mestrado } \\
\text { Acadêmico - } 1148\end{array}$ & 30 \\
\hline - & ESTELA & $\begin{array}{l}\text { CCP1027 - TRABALHO DE CONCLUSĀO DE } \\
\text { CURSO II }\end{array}$ & Pedagogia - Licenciatura Plena Diurno - 628 & 15 \\
\hline
\end{tabular}

\section{Aviso}

Turmas de cursos EaD ou sem alunos, não contabilizam encargo didático.

Fonte: Portal do professor/UFSM.

Figura 37 -

Encargos didáticos do primeiro semestre de 2020: 255 horas aulas.

Encargo didático

\begin{tabular}{|c|c|c|c|c|}
\hline & - Turma & = Disciplina & - Curso & F Encargo didático $(\mathrm{h})$ \\
\hline - & $11 \mathrm{ND}$ & $\begin{array}{l}\text { MEN1184 - ESTÁGIO SUPERVISIONADO } \\
\text { NOS ANOS INICIAIS DO ENSINO } \\
\text { FUNDAMENTAL }\end{array}$ & Pedagogia - Licenciatura Plena Noturno - 627 & 37.5 \\
\hline - & $11 \mathrm{NA}$ & $\begin{array}{l}\text { MEN1184 - ESTÁGIO SUPERVISIONADO } \\
\text { NOS ANOS INICIAIS DO ENSINO } \\
\text { FUNDAMENTAL }\end{array}$ & Pedagogia - Licenciatura Plena Noturno - 627 & 105 \\
\hline - & 11 & $\begin{array}{l}\text { MEN1280 - ORGANIZAÇÃO DA AÇ̄̃̄O } \\
\text { PEDAGÓGICA A }\end{array}$ & Pedagogia - Licenciatura Plena Diurno - 628 & 45 \\
\hline - & 11 & $\begin{array}{l}\text { CCP1032 - SEMINÁRIO INTEGRADOR II: } \\
\text { DESAFIOS DO PEDAGOGO NO CAMPO DA } \\
\text { DIVERSIDADE }\end{array}$ & Pedagogia - Licenciatura Plena Diurno - 628 & 30 \\
\hline - & $11 \mathrm{NF}$ & $\begin{array}{l}\text { MEN1183 - TRABALHO DE CONCLUSÃO DE } \\
\text { CURSO }\end{array}$ & Pedagogia - Licenciatura Plena Noturno - 627 & 22.5 \\
\hline - & ESTELA & $\begin{array}{l}\text { CCP1035 - TRABALHO DE CONCLUSÃO DE } \\
\text { CURSO A }\end{array}$ & Pedagogia - Licenciatura Plena Diurno - 628 & 7.5 \\
\hline 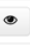 & ESTELA & $\begin{array}{l}\text { CCP1027 - TRABALHO DE CONCLUSÃO DE } \\
\text { CURSO II }\end{array}$ & Pedagogia - Licenciatura Plena Diurno - 628 & 7.5 \\
\hline
\end{tabular}

\section{Aviso}

Turmas de cursos EaD ou sem alunos, não contabilizam encargo didático.

Fonte: Portal do professor/UFSM. 
No ano de 2019 retornei ao Mestrado em Administração Pública, ministrando novamente a disciplina de Técnicas de Ensino (30h) e com uma orientanda: Denise Doná Linke. Ela está desenvolvendo um projeto de pesquisa na linha de Pedagogia e Política. Por este motivo o projeto é importante. Este projeto entra na discussão e interface com a área da Administração, principalmente na parte de gestão de pessoas e levanta a necessidade de transpor para o setor público algumas das práticas já consolidadas em termos de seleção e gestão de pessoal. Por exemplo, quando se trata de uma contratação de pessoal no setor privado, leva-se em consideração a natureza da função e o perfil de desempenho esperado pelo candidato, as necessidades e especificidades da filosofia da empresa: aderência do candidato à esta característica da filosofia da empresa - por exemplo, se o candidato é contra os produtos agrotóxicos, então ele não pode candidatar-se a vaga de técnico agrícola ou agrônomo numa empresa multinacional que pesquisa, fabrica e vende agrotóxicos. E, por óbvio que isso tudo possa parecer, no processo seletivo e posteriormente, nos processos de gestão de carreira dos professores, muito do que se pesquisa sobre a área ainda pode incorporar, principalmente na direção da qualidade da educação básica ofertada pela rede pública.

Além destas questões, discutir esta problemática no contexto atual das mudanças das políticas públicas tendo em vista as novas orientações da formação de professores, tendo em vista a BNCC formação e a BNCC para a educação básica, em especial a educação infantil e os anos iniciais. Este novo contexto das orientações legais pode se tornar potente para tratar de questões fundamentais sobre as exigências de formação, seleção e gestão de profissionais da educação básica. Sobre este assunto, muito poderia ainda refletir e compartilhar as minhas inquietações, certamente elas virão à tona no percurso da investigação da dissertação de mestrado da Denise Link.

\section{A presença de um grande mestre em minha formação}

Por fim, destaco, a presença do Maestro Acadêmico Antonio Meneghetti ao longo de todo o meu percurso formativo. $O$ conheci quando tinha 22 anos e, desde então, minha vida mudou radicalmente por conta de sua condução e orientação. É uma grande dádiva da vida ter conhecido, convivido e ter sido formada por ele. A grandeza da pedagogia descobri com ele. Foi por meio dele que me encantou a ideia de ser pedagoga, porém com uma práxis Ontopsicológica. Sua presença forte, perspicaz e profundamente humana me levou a estradas que jamais imaginei, os caminhos e os desafios foram extremamente fortes, grandes, para descobrir a minha grandeza - não no sentido de ser maior que outros, mas encontrar, valorizar e desenvolvê-la:

O espírito do homem tem a capacidade de ter a responsabilidade do todo. Os indivíduos humanos mortos há dois mil anos, por exemplo, sobrevivem hoje com o peso de suas ações determinando a nossa história. O indivíduo desaparece, enquanto a responsabilidade de suas ações sobrevive eternamente no todo como viva determinação do concreto contínuo. Todo e qualquer homem tem uma coincidência com o todo. Os efeitos das ações de um indivíduo mortal transmitem-se dinamicamente no futuro. A pequena 
ação de um homem tem a potencialidade de todo. Nós vemos apenas o seu início insignificante e imediatamente eliminado; na realidade, deu-se ato a algo impossível de ser interceptado. Cada homem transcreve-se como marca mnésico-dinâmica para sempre no todo em evolução. (Meneghetti, 2003b, p. 48)

Foram a partir destes princípios que responsabilizam profundamente a cada um de nós, humanos, mas principalmente como pessoa, os quais o Maestro Acc. Antônio Meneghetti foi nos conduzindo a talhar a nossa personalidade. Diante da vida, é fundamental humildade e persistência para se tornar um instrumento eficiente para si e deixar o legado para tantos outros.

\section{A guisa de conclusão}

Enfim, toda as minhas escolhas me trouxeram até onde hoje estou. Muitas atividades e horas aulas em toda a minha trajetória. Muitas orientações. Muitas viagens. Muita experiência internacional. Muitos contatos. Enfim, isso não me diferencia de ninguém. Talvez tenha feito menos ou mais, ou igual a tantos colegas.

Confesso que estava muito em dúvida, se escrever um memorial ou uma tese. Optei pelo memorial, pois tenho tantas ideias em elaboração e não encontraria tempo hábil para conseguir construir com o rigor que gosto de ter numa tese. Sem dúvidas, esta descrição formal de memorial não é a história que eu queria contar, mas foi a história que consegui contar. Depois, existe sempre o considero um problema: falar de si não é tão fácil quanto parece, pois penso que, dentro de um sistema, no caso educacional, acabamos sempre nos colocando na situação de vestir uma imagem, conforme aquilo que é aceito pelo grupo ou pelo contexto, ou do que entendemos ser o contexto. $E$ assim acabamos construindo uma imagem de nós mesmos que não é exatamente aquela que gostaríamos que fosse, mas aquela que foi possível por nós desenhar dentro dos limites de nossos estereótipos.

O que torna este meu memorial algo especial? As construções e aprendizagens subjetivas, as minhas tomadas de consciência, as minhas reflexões, as minhas melhorias e definitivamente as contribuições e marcas boas que deixei ao longo do tempo nas pessoas, nas instituições pelas quais passei. Então, o que valeu a pena foram as vidas que eu auxiliei com a minha vida, mas estas não vão no lattes, nem mesmo temos depoimentos, comprovantes ... nada disso! E, no final das contas, quando passamos a régua o que conta é as coisas belas da vida que não fazem parte da burocracia do sistema.

No sistema não existe personalidade, existe um número de CPF, de Siape - registro na UFSM -, e é só. Isso não significa que sou contra o sistema, ou algo do gênero. Muito pelo contrário, pois, "cada um pode fazer a sua pequena, aparente insignificante parte, mas a eficiência de si mesmo, de todo modo, é uma contribuição grandiosa na história do universo de todos: alguém que vence reacende nos outros a esperança de fazer o mesmo" (Meneghetti, 2003, p. 189). Esse trecho do pensamento de Meneghetti representa um pouco do que tentei expressar neste memorial. Da eficiência e da realização de meu trabalho coloco em movimento um conjunto de coisas: as boas e as nem tanto, sempre na minha medida, na medida do que eu faço e, portanto, sou. 
Me orgulho de não ter participado de tantas coisas das quais eu não acredito. $E$ me orgulho de poder ter participado de coisas as quais fizeram sentido para mim e me tornaram uma pessoa melhor. Foi uma trajetória diversa, mas não porque eu sou especial, mas porque eu sou diversa. Não me sinto melhor do que ninguém, sinto que poderia talvez ter feito muitas coisas e, de forma diferente. Mas sobretudo, como pensamento conclusivo deixo aqui a minha reflexão a partir deste pensamento que me conduziu durante todo o percurso:

Nós em Ontopsicologia começamos a deixar os doentes, um pouco porque aqueles que encontramos já os curamos; depois, porque somos poucos e aqueles poucos que somos em Ontopsicologia consideramos econômico endereçar a psicoterapia de autenticação a todos os homens de poder sobre o social. Um neurótico está mal, faz mal a si mesmo e a sua família; um político faz chacina ou o suicídio da humanidade. Nós cientistas, não é a bomba atômica que podemos temer, mas o papel obscuro dentro do inconsciente de alguns políticos; porém nós cientistas não devemos focar sobre estes, mas trabalhar hoje para ter, daqui a cinquenta anos, políticos autenticamente humanos (Meneghetti,1985, s/p).

\section{Referências}

BRASIL. Resolução CNE/CP n. 2, de 20 de dezembro de 2019. Disponível em: <http://portal.mec.gov.br/docman/dezembro-2019-pdf/135951-rcp002-19/file> Acesso em: 25 ago. 2021.

MENEGHETTI, Antonio. Dicionário de ontopsicologia. 1. ed. Recanto Maestro: Ontopsicológica, 2012.

MENEGHETTI, Antonio. Pedagogia ontopsicológica. 2. ed. Recanto Maestro: Ontopsicológica, 2014.

MENEGHETTI, Antonio. Psicologia da organização. São Paulo: Foil, 2003.

MENEGHETTI, Antonio. Filosofia ontopsicológica. Florianópolis: Ontopsicológica, $2003 \mathrm{~b}$.

MENEGHETTI, Antonio. Atos do XI Congresso Internacional de Ontopsicologia. Roma, 1985.

VIDOR, Alécio. Relação pais e filhos: origem dos problemas. Recanto Maestro: Ontopsicológica, 2014.

Estela Maris Giordani é professora na Universidade Federal de Santa Maria.

Orcid: https://orcid.org/0000-0002-7907-6125.

Endereço: Avenida Roraima, 1000 - prédio 16 - 97105-900 - Santa Maria - RS Brasil.

E-mail: estela.giordani@ufsm.br.

Critérios de autoria: Estela Maris Giordani concebeu o texto na sua integralidade.

Recebido em 30 de agosto de 2021.

Aceito em 12 de setembro de 2021.

(c) $(1) \Theta \Theta$

Regae: Rev. Gest. Aval. Educ.

Santa Maria

v. 10

N. especial

e67467, p. 1-60

2021 